\title{
WestVirginiaUniversity
}

THE RESEARCH REPOSITORY @ WVU

Graduate Theses, Dissertations, and Problem Reports

2010

\section{Mythscapes: Violent Spaces in Postmodern Literature and Culture}

Jonathan R. Harvey

West Virginia University

Follow this and additional works at: https://researchrepository.wvu.edu/etd

\section{Recommended Citation}

Harvey, Jonathan R., "Mythscapes: Violent Spaces in Postmodern Literature and Culture" (2010). Graduate Theses, Dissertations, and Problem Reports. 3256.

https://researchrepository.wvu.edu/etd/3256

This Dissertation is protected by copyright and/or related rights. It has been brought to you by the The Research Repository @ WVU with permission from the rights-holder(s). You are free to use this Dissertation in any way that is permitted by the copyright and related rights legislation that applies to your use. For other uses you must obtain permission from the rights-holder(s) directly, unless additional rights are indicated by a Creative Commons license in the record and/ or on the work itself. This Dissertation has been accepted for inclusion in WVU Graduate Theses, Dissertations, and Problem Reports collection by an authorized administrator of The Research Repository @ WVU.

For more information, please contact researchrepository@mail.wvu.edu. 


\title{
Mythscapes: Violent Spaces in Postmodern Literature and Culture
}

\author{
Jonathan R. Harvey \\ Dissertation submitted to the \\ Eberly College of Arts and Sciences \\ at West Virginia University \\ in partial fulfillment of the requirements \\ for the degree of \\ Doctor of Philosophy \\ in \\ English \\ Kathleen Ryan, Ph.D., Chair \\ Charles Baldwin, Ph.D. \\ Gwen Bergner, Ph.D. \\ Ryan Claycomb, Ph.D. \\ Lisa Yaszek, Ph.D. \\ Department of English
}

Morgantown, West Virginia

2010

Keywords: postmodern fiction; speculative literature; violence; marvelous space; gender studies; cultural studies. 


\title{
ABSTRACT \\ Mythscapes: Violent Spaces in Postmodern Literature and Culture
}

\author{
Jonathan R. Harvey
}

This project focuses on British and American speculative novels written between the 1960s and the 2000s that position the reader to critique the contemporary world. Depictions of violent, fictional spaces, or what I call mythscapes, are playing an influential role in literary, political, religious, and even scientific discourses. The mythscape can initiate introspection on real issues by suggesting possible alternatives, conjecturing about potential consequences, and posing compelling comparisons. I define "mythscape" as an imagined space that features: a setting that is nonrealistic and radically different from, yet implicitly contrastive with, material reality; a rhetorical stance, which is inevitably grounded in the author's historical and cultural moment; and the depiction of violent acts which are designed to shock and disturb while engaging the sympathetic emotions of the reader. Such imagined spaces could be fertile ground for rhetorical manipulation: consider, for example, individuals who have moderated their behavior due to imagined fears of the afterlife. Determining the argumentative designs and possible social impacts of such imagined spaces is the primary goal of my analysis. 


\section{TABLE OF CONTENTS}

Chapter 1: Defining the Mythscape ….................................................. 1

Chapter 2: From the Ruins of the Post-Apocalyptic Feminist Novel ......................... 24

Chapter 3: Antiwar Dystopias and the Myths of Postmodern Wars ............................ 62

Chapter 4: The "Wild West" and the "New Weird" ........................................ 92

Chapter 5: The Surreal, Pornographic Worlds of Carter and Acker .......................... 119

Chapter 6: Mythscapes in Post-Millennial Culture ........................................ 147

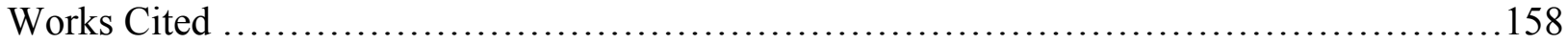




\section{Chapter 1: Defining the Mythscape}

Mythmakers often engage our deepest fears-death, powerlessness, global destruction, torture, perpetual warfare - and arouse in us the desire for transformation, whether spiritual, personal, or political. Such "mythology is certain to participate in the making of the world," as Roland Barthes has famously argued (156). Depictions of violent, fictional spaces, or what I call mythscapes, are playing an influential role in literary, political, religious, and even scientific discourses. A tactical space from which to launch radical arguments about our world, a mythscape is a marvelous setting featuring violent imagery and a specific rhetorical purpose. These mental spaces are part of an imaginative cultural heritage of folklore and religion, from fairy tales to allegories, from descriptions of the afterlife to prophecies of the end of the world. In contemporary literature, mythscapes are often found in speculative fiction, a literary field which includes science fiction, fantasy, and, to some extent, surrealism, horror, and magic realism. Modern and postmodern readers do not necessarily "believe" in the actual presence of these mythscapes, but they can be influenced by them nonetheless, as I will argue.

This project focuses on British and American speculative novels written between the 1960s and the 2000s that position the reader to critique the contemporary world. My approach to these texts is mindful of Baz Kershaw's analysis of theatrical performances which have "the potential...to achieve efficacy in a particular historical context" (3, emphasis in original). Likewise, the mythscape can initiate introspection on real issues by suggesting possible alternatives, conjecturing about potential consequences, and posing compelling comparisons. Mired in the mundane - a word whose roots are analogous to the Latin term for "world"readers can find it difficult to disentangle themselves from the apparent reality imposed by culture. The process of reading superimposes an imagined world upon the material reality of the 
text and the reader, and in this perceptual dislocation between the mundane and the fictional, there is a recursive space of comparison and critique. Such an imagined space is rife with possibility, and it is not unique to speculative writing; consider Helene Cixous's comment urging women to write because "writing is precisely the very possibility of change" $(879$, emphasis in original). Speculative fiction is just particularly suitable for this analysis because it presupposes a world unlike our own, and as Darko Suvin writes, science fiction "sees the norms of any age, including emphatically its own, as unique, changeable, and therefore subject to a cognitive view" (7, emphasis in original).

Over the past several decades, scholars like Suvin have been arguing for a legitimization of speculative fiction, which is often tagged with the stigma of being less-than-literary "genre" fiction. Rather than addressing real world issues directly, so the argument goes, much speculative fiction is regarded as escapist, resulting in statements like those by Benjamin Kunkel, who writes that "genre fiction typically offers consolation at the expense of illumination" and blasts its lack of "moral imagination," "stale language, secondhand insights, [and] hackneyed plots" (95). Despite the proliferation of such generalizations about speculative fiction, I contend that mythscapes can be effective tools of argument. The unreal aspects of the setting and narrative can unmoor readers from the everyday, the "'zero world' of empirically verifiable properties" (Suvin 11), and instigate critical reflection on our world, its people, and our fears and wishes. Just as fairy tales can, in Marina Warner's terms, “encipher concerns, beliefs and desires in brilliant, seductive images that are themselves a form of camouflage" (xxi), mythscapes take an oblique approach to argument. Imagined spaces can have a powerful effect on personal decisions: consider, for example, individuals who have moderated their behavior due to imagined fears of the afterlife. Henri Lefebvre refers to the psychological influence which imagined space 
might have on readers when he describes "the fictitious/real space of language and that of mental space, magically (imaginarily) cut off from the spatial realm, where the consciousness of the 'subject'—or 'self-consciousness'-takes form" (236). If subject formation occurs in an imagined space, a mental landscape tailored by language and colored by affect, then this intimate, infinitely mutable space could be fertile ground for rhetorical manipulation. Determining the argumentative designs and possible social impacts of such imagined spaces is the primary goal of my analysis.

Since I am focusing on mostly postmodern texts, I will attempt to briefly parse how postmodern mythologizing contrasts with pre-modern and modern forms of mythmaking. "[M]odernism tends toward the monumental and the mythic, while postmodernism works to undermine such totalizing structural principles" by focusing instead on "the marginal, the fragmentary, and the heterogeneous" (Freedman 182). The mythscapes I analyze are not products of grand narratives widely believed by a culture, but rather narrative spaces conceived as heuristic possibilities and compelling forms of argument. Perhaps this relates to postindustrialized western culture's "changing notions of what exactly constitutes 'reality,"” as Rosemary Jackson describes in relation to the evolution of fantasy literature (4), which are, of course, in sharp contrast to monolithic notions of the real. Postmodern art tends to lack "an effective theory of agency that enables a move into political action," as Linda Hutcheon claims (3, emphasis in original), rendering postmodernism's wry skepticism of truth conducive to a state of indifference. But since postmodern art "cannot but be political, at least in the sense that its representations - its images and stories—are anything but neutral" (Hutcheon 3), its aesthetic qualities are as important as, or even less important than, its inherent arguments. Thus, while postmodern myths cannot aspire to be universal truths, they are always traceable to a particular 
political stance or ideology and therefore do not provide closure so much as engage in a dialectic. Interestingly, Jackson notes that post-industrial fantasies tend to be "peculiarly violent and horrific" (4). Fear and violence are also recurring themes in my analysis of mythscapes, suggesting a popular aesthetic feature of postmodern rhetoric in a world in which even the nature of reality is subject to constant debate.

The mythscape is a critical, violent, and imaginary space that is conceived in contrast to the material reality. War-torn futures confront us with the possible trajectories of our violent present; distant worlds peopled with sentient beings challenge us to consider our own planet from a new angle; apocalyptic landscapes emphasize the fragility of our modern civilization. I define "mythscape" as an imagined space that features:

- a setting that is nonrealistic and radically different from, yet implicitly contrastive with, material reality;

- a rhetorical stance, which is inevitably grounded in the author's historical and cultural moment;

- the depiction of violent acts that are designed to shock and disturb while engaging the sympathetic emotions of the reader.

These three elements are intertwined and dialectical, and they will inform this topoanalysis of the mythscape. In Poetics of Space (1958), Gaston Bachelard defines topoanalysis as "the systematic psychological study of the sites of our intimate lives" (8). Bachelard provides a model for analyzing the impact of literary space on readers based on our pre-existing notions of actual spaces, especially within and around homes: depictions of attics, basements, cupboards, and so forth become, in Bachelard's view, receptacles for deep-seated, often subconscious significance which writers might use for literary affect. In a similar mode, I examine numerous mythscapes 
from postmodern fiction and analyze their intended rhetorical effects, though my focus is on speculative spaces at a far remove from the home - e.g., a distant planet or a dystopian futureand "into the sphere of anthropological and cosmological thought" (Suvin 12). In this way, mythscapes provide insights into our collective world.

\section{The Tactics of Time:Space}

Certain literary theories of space imbue narrative environments with profound significance, supporting the assertion that fictional spaces are capable of potent rhetorical effects. Mikhail Bakhtin defines chronotope as the confluence of time and space in narrative literature. Unlike the term setting, a chronotope semantically unifies time and location into a dualism upon which other narrative elements, like character and plot, fully depend (85). For Bakhtin, narrative meaning is contingent upon an awareness of time and place; similarly, the chronotope of a mythscape is closely tied to the meanings of the narrative. These environments directly, sometimes incessantly, influence character action, and their influence on plot is often pervasive: for instance, surviving in a post-apocalyptic nuclear wasteland, or making imperialistic war on another planet, is the subject of the narrative.

Realistic fictional settings are by definition limited by the natural laws we can perceive and by the cultural possibilities that exist or have existed. As Gloria Anzaldúa contends, "Culture forms our beliefs. We perceive the version of reality that it communicates. Dominant paradigms, predefined concepts that exist as unquestionable, unchallengeable, are transmitted to us through the culture" (1018). In this view, realism is strategic, in Michel de Certeau's sense: it limits fictional settings to what is known about place. Leonard Lutwack argues that verisimilitude in fiction is not contingent on a fictional place's congruence with an actual place, but rather on 
whether readers "accept the illusion of a place's facticity" (30). However, adhering to this illusion could be viewed as a strategy of realism that limits fiction to the mundane and conforms writing to a certain standard of plausibility—naturally or culturally defined limitations of what is considered possible. ${ }^{1}$

Mythscapes need not maintain such illusions. They are ersatz tactical spaces unburdened by adherence to historical realities or, in case of fantasy and surrealism, even natural laws. "The space of a tactic is the space of the other," as de Certeau claims (1253), and beyond the real, there are infinite other spaces which can be imagined. In her analysis of fantastic literature, Jackson uses language suggestive of such tactical subversion: the fantastic's "impossibilities propose latent 'other' meanings or realities behind the possible or the known. Breaking single, reductive 'truths,' the fantastic traces a space within a society's cognitive frame" (23). Similarly, Marina Warner proposes that the fantastic elements within "the atmosphere of fairy tale disrupt the apprehensible world in order to open spaces for dreaming alternatives" $(\mathrm{xx})$. A prince transformed into a frog, for example, upsets the culturally mandated hierarchy of the nobility's superiority and reminds us that even the highborn are really only animals. Like a tactic, imagining the unreal is a subversive move; the whimsical unreality of fairy tales "mak[es] it possible to utter harsh truths, to say what you dare" (Warner xxi). Speculative fiction opens up an imagined tactical space in which taboos can be violated and "unrealistic" possibilities dramatized.

Genre conventions contribute to the world-building process of imagining a mythscape. A reader's expectation of a fantasy story, for instance, involves "a fiction of consensual construction of belief," as Farah Mendlesohn claims; "This expectation is historical, subject to historical change, and is not unique to fantasy," but occurs in any engagement with literary 
genres (xiii). We need not "believe" in the marvelous per se, but in order to fully immerse ourselves in a mythscape, we must be willing to suspend our disbelief, an act that can be conditioned by notions of genre expectations. Several novels in this study build on these readerly positions. The feminist post-apocalyptic novels in Chapter Two rely upon science fiction tropes, although three of the authors (Angela Carter, Doris Lessing, Jeannette Winterson) are more known for their "literary" writing. The antiwar novels of Chapter Three also draw from science fiction, but other texts, including the New Weird novels in Chapter Four and the surrealist erotica of Chapter Five, defy or playfully manipulate well-known genre conventions. Such manipulation is, in turn, a generic convention of the so-called New Weird, and the surrealist erotic novels parody romance fictions. At the level of world-building, generic slipperiness emulates the sense of radical, pervasive social changes for which the narrative content of these texts also argue. Despite de Certeau's claim that "[t]here is no longer an elsewhere" (1255), there can be any number of imagined elsewheres, like mythscapes, which could lead to a reassessment of our existing places. In Space and Place: The Perspective of Experience, Yi-Fu Tuan describes how all human cultures imagine mythic spaces outside the borders of known places. He writes, "Mythical space is an intellectual construct....[It] is also a response of feeling and imagination to fundamental human needs" (99). When an author is dissatisfied with his or her present reality, constructing an alternate world through narrative is an intellectual exercise that channels negative emotions and satisfies a fundamental yearning for something better. Altering elements of the real world in fiction can also be viewed as a liberatory experience, freeing up the author and reader from real world constraints. This is similar to how surrealist literature "introduces an atmosphere having the effect of liberating modes of thought and action" (Matthews 176, emphasis added): unreal spaces encourage a radical freeing-up of perception and thought, and 
acts of real change might emerge from the cognitive process of imagining such spaces. If we can imagine unreal spaces, then perhaps we can also conceive realistic alternatives beyond the apparent limits imposed by culture: "The fantastic traces the unsaid and the unseen of culture: that which has been silenced, made invisible, covered over and made 'absent'" (Jackson 4). Read in this way, speculative literature is much more than escapist—it is radical, visionary literature that can expand the horizons of possible thought.

\section{Trait \#1: Mythscapes feature settings that are nonrealistic and radically different from, yet implicitly contrastive with, our material reality.}

Scholars of speculative fiction have theorized extensively about this concept. Suvin's renowned proposal about science fiction is that it generates "cognitive estrangement" about our world, acting as a mirror that both reflects and transforms the "naturalistic" world (10-11). "[T] he attitude of estrangement," Suvin writes, is a "cognitive and creative" process which involves "confronting a set normative system... with a point of view implying a new set of norms" (6, emphasis in original). That is, speculative fiction challenges what we take for granted as normal by describing in detail a recognizable but fundamentally abnormal world. This Brechtian distancing from our everyday world is a key aspect of the mythscape, as it establishes a critical objectivity between the subject and reality, temporarily interrupting the subject's perception of the real world. Robert Scholes describes how speculative fiction can operate argumentatively through a term he calls "fabulation," which is "fiction that offers us a world clearly and radically discontinuous from the one we know, yet returns to confront that known world in some cognitive way" (29). The rhetorical potential of the mythscape manifests when confrontation with a "radically different" setting goads the reader into critically re-examining the 
material world.

Mythscapes explore the material world's potential for change by suggesting possible alternatives. Bachelard explains that "the imagination, by virtue of its freshness and its own peculiar activity, can make what is familiar into what is strange. With a single poetic detail, the imagination confronts us with a new world" (134). Such strangeness lends the unreal space its potential for an imaginative reassessment of reality, which can be interpreted as "a diagnosis, a warning, a call to understanding and action, and — most important—a mapping of possible alternatives" (Suvin 12). Taking the familiar and the mundane as its foundation, mythscapes often alter one or more significant details to create a fictional environment in which to explore heuristic possibilities: what might life be like 200 years in the future? What could the world look like after apocalypse? What if our current global wars never ended and became intergalactic conflicts? Is the afterlife a fantastic geographical realm? Creators of mythscapes build a marvelous setting in which to dramatize their answers to such questions.

Many mythscapes express fears and wishes about the future. While in the past humans often speculated on marvelous places that could exist in the world beyond their knowledge, ${ }^{2}$ advanced societies ideally have a much more developed awareness of what exists across the planet. Not so for the future, wherein—we alternately dread or hope — any type of world could exist. Carl Freedman writes that futuristic fiction functions critically "as a locus of radical alterity to the mundane status quo, which is thus estranged and historicized as the concrete past of potential future" (55). Thus, the future in fiction, no matter how strange, must somehow reference the present world.

Mary Shelley speculates on the possible future of the $19^{\text {th }}$ century world in her 1826 novel The Last Man, in which the protagonist Lionel Verney becomes the sole survivor of a 
plague that destroys humanity. The novel is both a science-fictional dystopia and a space in which to experiment with sociological possibilities. The future setting of the mythscape allows Shelley to extrapolate from her era and imagine the end of the English monarchy, an ongoing war between Turkey and Greece, and the unstoppable ravages of a new plague. Rather than being figured as "pure fiction," works of futuristic fiction "describe events that retain their potential for coming true" (O'Dea 294). Written by a progressive Romantic, The Last Man speculates on a future liberated from old-world tyrannies while conveying more general fears of solitude and the ultimate end of human civilization altogether. The radical potential of such a futuristic dystopia should engage the anxieties we share for the future so that readers are eager to help shape a better future. This is the general motivation behind the post-apocalyptic feminist novels I examine in Chapter Two. These novels take for granted that patriarchal wars and humanity's general penchant for destruction will inevitably ruin the planet. They express frustration with the dominance of patriarchy while yearning for a chance to start out fresh in a new civilization.

The future is only one possible means of displacing the world of the mythscape from the present. Novels set on distant planets, or even alternate worlds beyond our current limits of perception, usually feature aspects of this world in order to suggest arguments of comparison. China Miéville's invented world of Bas-Lag, which I discuss in Chapter Four, has no apparent ties to our Earth—no space-traveling Earthlings dwell there, for instance—-but it is peopled by humans and humanoids who live in industrialized cities and engage in racially charged conflicts and political machinations. We see ourselves in these impossible worlds, so Miéville can embed his progressive political arguments within them. Tolkien's Middle-Earth, the visited planets of space operas like Star Wars, and many fantasy and science fiction worlds are also much more 
like Earth than not, with forests, castles, cities, sentient bipeds, and so on. On worlds in which the similarities to our world are not readily apparent—such as in Stanislaw Lem's Solaris (1961), in which the world itself is a sentient, amorphous mass that manifests illusions out of intruders' memories - the incommensurability between the alien world and our own becomes the source for the plot's entire conflict. ${ }^{3}$

Mythscapes may also be nested within the real world or superimposed upon it. ${ }^{4} \mathrm{An}$ example of the former is H. P. Lovecraft's "The Horror At Red Hook" (1927), in which a portal to a hellish underworld beneath the Red Hook district of Brooklyn, New York, threatens to destroy the America of the author's nostalgic past: "here lay the root of a contagion destined to sick and swallow cities, and engulf nations in the foetor of hybrid pestilence...[I]n this quintessence of all damnation the bounds of consciousness were let down, and man's fancy lay open to vistas of every realm of horror and every forbidden dimension that evil had power to mould" (Lovecraft 239). This sub-world is conveyed in the language of an absolute morality that pits good vs. evil, past nostalgia vs. future apocalypse, and racial purity vs. miscegenation. The imaginary space's connection to our world is stressed through Lovecraft's realistic descriptions of Red Hook (and tainted by his racist perspective). An example of the "superimposed" mythscape is found in Angela Carter's The Infernal Desire Machines of Doctor Hoffman (1972), described in Chapter Five. What begins as a seemingly real city in present-day South America becomes distorted by the eponymous Machines, which generate an environment in which whimsical desire physically transforms the real. Though it creates conditions that are impossible, dreamlike, and absurd, Carter's novel interrogates how real desires are intertwined with power, a connection that is dramatized by the fictional environ itself.

The displacement of the unreal setting in relation to the time and place of the real world 
is thus crucial to the mythscape as a critical apparatus. Dystopian futures are warnings extrapolated from the perceived trajectory of the present. Alternate worlds suggest a multiplicity of global perspectives and open up our conceptualizations of what a "world" is. Unreal spaces embedded or superimposed over our reality highlight the instability of the present, or else dramatically distort actual conditions of the real world. In each case, similarities are juxtaposed with fundamental differences, and the potential for comprehensive critiques of how we perceive our world and our notions of reality thrive in this recursive space between the real and the mythscape.

Trait \#2: Mythscapes are built according to the specific rhetorical stance of the author, which is inevitably grounded in his or her historical and cultural moment.

Each mythscape is created with the particular contemporary rhetorical designs of an author. This is, of course, true of any politically conscious literature, and Hutcheon would say it is true of any postmodern art (1). But for the mythscape, these designs are disguised as fanciful, nonmimetic elements which highlight the critical differences between the unreal setting and the real world. There is an ineluctable dialectic between the first two traits of the mythscape: the marvelous elements of the mythic space are crucial to understanding the author's rhetorical designs, and vice versa. These marvelous elements tend to critique both the particular and the universal as they shift implied representations between contemporary historicization and broader sociopolitical issues. In Nineteen Eighty-Four (1949), George Orwell condemns what his generation witnessed of the Nazis' anti-Semitic scape-goating via the fictional figure of Goldstein, and at the same time, he offers warnings about totalitarian governments in general via depictions of the pervasive state surveillance in Oceania. Displacement from the real imbues them with this 
symbolic fluidity.

Because the mythscape is often conceived on a macroscopic level, it has the potential to schematize large-scale, radical reassessments of the material world. I use the term "radical" in a denotative rather than political sense, for the deeply rooted critiques posed by a mythscape certainly need not be progressive. Lovecraft's “The Horror at Red Hook" conveys a reactionary sense of horror regarding the encroachment of nonwhite immigrants. The Left Behind series (1995-2007) by Tim LeHaye and Jerry B. Jenkins describes the end of the world in Biblical terms, interpreting Revelations and other apocalyptic prophesies in narratives featuring contemporary characters to convince readers that the end is near and that fundamentalist Christianity is the only way to salvation. The arguments proposed by mythscapes are thus radical in the sense that they are usually sweeping and deeply rooted, as evidenced by the grand scale of their settings and the ambitious rhetorical approaches of their authors.

A strong example of a historically specific and retrospectively effective mythscape can be found in Rachel Carson's Silent Spring (1962), particularly the famous opening chapter entitled "A Fable for Tomorrow." This chilling vision of a pesticide-ridden planet is an iconic mythscape to which some scholars (e.g. Buell 295) trace real political effects. Initially, an unnamed town in America is a vision of suburban and agrarian harmony, but then,

a strange blight crept over the area and everything began to change. Some evil spell had settled on the community: mysterious maladies swept the flocks of chickens; the cattle and sheep sickened and died. Everywhere was a shadow of death...There was a strange stillness. The birds, for example — where had they gone?...It was a spring without voices...only silence lay over the fields and woods and marsh...The roadsides, once so attractive, were now lined with browned and 
withered vegetation as though swept by fire. These, too, were silent, deserted by all living things... No witchcraft, no enemy action had silenced the rebirth of new life in this stricken world. The people had done it themselves. (2-3)

Carson's widely publicized text fomented organized political action against toxic chemicals like DDT (Buell 295). "A Fable for Tomorrow" is a particularly cogent example of a mythscape's potential for real social change: Carson perceived a problem specific to her era and extrapolated a possible future if the problem was not solved. Chapter Six describes how some current environmental activists continue to evoke possible futures, attempting to convince their contemporaries of the need for sweeping alterations to the way we coexist with our planet. Historicizing a mythscape entails identifying how its authorial designs are relevant to a real time and place. My approach highlights differences between otherwise similar novels collected in each chapter. Writing thirty years apart from one another, Joe Haldeman and Bill Campbell offer two novelistic critiques of war, detailed in Chapter Three, which are remarkably alike on the surface, but divergent in their rhetorical priorities. Haldeman's The Forever War (1974) features an imperialistic war between humans and Taurans set in the distant future but published in an era notorious for polarizing debates about America's involvement in Cold War militarization. The author's experiences in the Vietnam-U.S. War influenced his first-person narration of a hyperbolic future war that critiques racially motivated xenophobia and modern war in general. Campbell also depicts a futuristic conflict in Sunshine Patriots (2004), in which a war on another planet recalls our own past and current wars against other countries. Campbell, however, poses post-Cold War critiques of American imperialism and global capitalism. This contrast reveals how critiques of American militarism tend to broaden scope during the postCold War era: rather than questioning the value of one misguided conflict, the criticisms are 
directed at a monolithic system whose object of conquest becomes the entire universe.

Even marvelous elements reflect an author's contemporary concerns; yet because they are not directly describing actualities, they can be interpreted variously as historicization, allegory, parody, and so on. Mythscapes seem to be about marvelous worlds but they are truly about reality, which is distorted and exaggerated to demonstrate the mutability of the world. Every author in this study is more a politically conscious observer than an escapist, and the richness of meanings in speculative fiction affirms that writing about the marvelous can be as erudite and temporally relevant as more "literary" texts.

\section{Trait \#3: Mythscapes depict violent acts that are designed to shock and disturb while engaging}

\section{the sympathetic emotions of the reader.}

This project's main innovation to the discipline of literary criticism is its analysis of fictional violence as rhetoric, a concept which surely merits more study. The definitive element of violence limits the mythscape's textual field to only those speculative narratives that feature a preponderance of violent imagery. The goal of such violent imagery is to generate negative emotions (fear, disgust, anger), or positive emotions (empathy, compassion) to convince readers to think or act a certain way. In short, the violence in a mythscape is closely related to the text's rhetoric. Rather than instigating catharsis, as in Greek tragedy, this violence tends towards alienation and dislocation. "Let the atrocious images haunt us," Susan Sontag implores in regards to photographs of war (115), and the violence in a mythscape is similarly designed to be harrowing and memorable so that readers are profoundly affected by it. We are meant to vicariously experience the violence of the setting in the hope that an automatic, negative bodily response, similar to Julia Kristeva's concept of abjection, will result in a compulsion to act in 
accordance with the text's rhetoric. Kristeva is physically repulsed by milk (2-3), a corpse (3), and a pile of shoes in an Auschwitz museum (4), and these bodily reactions compel her to consider her own subject-formation and, more generally, how such feelings have the power to instill meaning, especially in literature (208). The violence in a mythscape also attempts to trigger abjection in readers so that their minds and bodies are compelled to act in accordance with the author's argumentative designs.

A paradigmatic example of violence within a mythscape is Dante's Inferno. This epic poem is set in a mythical space conceived around the precise notion that unreal representations of violence are an effective means of influencing human behavior. The episode featuring Ugolino from Cantos XXXII and XXXIII exemplifies this claim. Ugolino is condemned to perpetually devour the head of the man whom he believed caused his demise, Archbishop Ruggieri. Dante depicts the terrible suffering of the damned in Hell, and this violent imagery triggers the reader's empathy and creates suspense while the sinner tells his story: "I saw two souls together / in a single hole, and so pinched in by the ice / that one head made a helmet for the other. / As a famished man chews crusts - so the one sinner / sank his teeth into the other's nape / at the base of the skull, gnawing his loathsome dinner" (Canto XXXII, lines 124-132). With this gory scene, Dante references the real-life horror of Ugolino's death—he starved to death after being locked in a tower with his sons and grandsons, who shared his grisly fate — and exploits the reader's engagement with the gruesome imagery to deliver a damning commentary on the political circumstances surrounding the Count's demise. The mythscape performs its role in this way by shocking and frightening readers with images of violence in the hopes that they might meditate on this possible future - at least, to a medieval Christian — and repent before it is too late. 
The rhetoric of postmodern mythscapes is likewise interwoven with depictions of violent imagery. One of the most well-known examples of a prolifically violent future setting in postmodern literature is Anthony Burgess's A Clockwork Orange (1962). This dystopia describes a world in which young people rove in rapacious gangs that brutalize the weak; the police, in response, beat any criminals they can catch; and the government's drastic Ludovico Technique subjects the worst offenders, like the protagonist Alex, to an overload of violent imagery that attempts to subdue the youth's propensity for violence. In this bleak future, violence begets violence, and the reader has difficulty deciding who to fear more, the heavy-handed government or the uncontrollable youths. As Burgess's "ultra-violent" novel demonstrates, the violence in a mythscape is frequently pervasive.

The antiwar mythscapes in Chapter Three expose the horrors of war, demonstrating how our weapons advance with time but our mortal bodies remain painfully vulnerable. The Forever War and Sunshine Patriots both depict violence suffered by the soldiers fighting for Earth, "our" side. One poignant example from The Forever War occurs when the protagonist's love interest, Marygay, is gruesomely wounded by a faulty space suit. The description is designed to generate an abject revulsion: the wound "traveled between her breasts until it passed the sternum's support...and opened up into a cut that got deeper as it ran down over her belly where it stopped... a few centimeters above the pubis a membraned loop of gut was protruding" (Haldeman 96). Just as the violent imagery of Ugolino in Inferno repels readers from sin, this episode warns us against the constant dangers of high-tech war, where even in "safe" transports, the soldier is exposed to violence.

Authors of mythscapes use violent imagery for reasons similar to the violent protests described by Slovoj Žižek. He claims that frustrated rioters, such as those in France in 2005, lash 
out in violence "to signal that they were a problem that could no longer be ignored....Had they organised a non-violent march, all they would have got was a small note on the bottom of a page" (77). Violence demands attention. Even if they do not directly threaten us, images of violence transfix us, disrupt normalcy, and create signposts in our memories. This is why whole generations can so distinctly recall their initial exposures to John F. Kennedy’s assassination, or

the planes striking the buildings on September 11, 2001. Like abjection, which "simultaneously beseeches and pulverizes the subject" (Kristeva 5), violent imagery seizes our interest while turning our stomachs. Creators of mythscapes use it to build suspense and unsettle readers by compelling them to witness "what humans are capable of inflicting in the way of gruesome, hands-on cruelties upon other humans" (Sontag 114). Even fictional images of violence are, for better or worse, memorable; they ensure that readers will not easily forget the harrowing experience of sojourning to a mythscape.

\section{Chapter Summaries}

Chapter Two, "From the Ruins of the Post-Apocalyptic Feminist Novel," examines four post-apocalyptic feminist novels: Angela Carter's Heroes and Villains (1969), Doris Lessing's Memoirs of a Survivor (1974), Octavia Butler's Parable of the Sower (1993), and Jeanette Winterson's The Stone Gods (2008). While each has varying degrees of violent imagery, all are united in foregrounding massive destruction that causes the downfall of modern civilization. This predetermined violence is a consequence of patriarchal civilization's inclination towards war and destruction; from the ashes of man's ruined world, these authors consider how, if at all, societies can rebuild to avoid the errors of the past. The novels by Lessing and Butler seem optimistic that new, feminized modes of thinking and acting will eventually lead to a better rebuilt world. The 
novels by Carter and Winterson suggest that old patterns will inevitably replicate themselves, and a cycle of destruction will continue.

Across the spectrum of five decades in which these authors are writing, the evolution of apocalyptic fears as well as differences in feminist approaches become apparent. Carter conveys Cold War nuclear paranoia in a devastated future rife with mutated beings. She also demonstrates a yearning for female empowerment, in which a woman ultimately possesses the brute force of social dominance formerly controlled by men. Lessing's novel demonstrates a gradual breakdown of civilization and the necessity for pluralistic changes, not only to our social arrangements, but to our mindsets as well. Butler's novel seems to emphasize the need for collective change as well, but hers is a gritty, ruthless near-future in which violence and faith are necessary to protect the struggling new communities, and a renewed empathy is crucial to our continued survival. Winterson reveals post-millennial anxieties about ecocatastrophe rather than widespread nuclear destruction, and her heroine/hero shifts gender roles and sexualities, which suggests that a freeing-up of traditional genders is crucial to real cultural change. Rather than simply empowering females and disenfranchising males, Winterson's novel interrogates the traditional binary distinction between genders. This reflects later feminist ideology, influenced by queer theory, which analyzes how gendered norms are complicit in maintaining or subverting existing hegemonies. Analysis of the speculative elements in these novels reveals changing priorities in feminist thought, progressive ideology, and anxieties about our future.

Chapter Three, “Antiwar Dystopias and the Myths of Postmodern Wars," examines Haldeman's The Forever War and Campbell's Sunshine Patriots. These antiwar mythscapes are imaginative counter-arguments to popular pro-war myths used to support the real conflicts happening when each book was published, the Vietnam War and the War on Terror, 
respectively. If pro-war myths like Saddam Hussein's alleged "super-villain" status or his nonexistent plots to use weapons of mass destruction can encourage popular support for war, then these novels' hyperbolic depictions of future wars can illumine the faults of military aggression and bolster support for peace efforts. While both antiwar mythscapes rely on wellestablished science fiction genre tropes—-space travel, alien encounters, and futuristic weaponry — the authors are cynical of the value of these technological advances, as their critical, even at times satirical, tones suggest. In the excessive violence of the novels' interstellar conflicts as well as the nearly impossible distance and duration of the battlegrounds, readers glimpse haunting similarities to our real wars. Both writers depict how imperialistic warfare oppresses soldiers as well as the enemy; but The Forever War depicts this oppression as a result of temporal-physical distance and personal alienation between soldiers and civilians, while Sunshine Patriots portrays it as a consequence of the soldiers' enslavement to a capitalist empire. Both future militaries include male and female warriors, but in Campbell's world the military is segregated by race. Campbell's novel even seems to cross generic boundaries from science fiction to fantasy when the apparent magic of the alien planet affects the outcome of the war. The contrasts between these similar mythscapes, in addition to reflecting each author's contemporary concerns, demonstrate the nuanced versatility of marvelous symbolism. The hyperbolic violence featured in each reveals how excessive violent imagery can support nonviolent causes.

Chapter Four, "The 'Wild West' and the 'New Weird,"' analyzes traits of the Western genre in two "New Weird" novels, China Mieville's Iron Council (2004) and K.J. Bishop's The Etched City (2003). These novels, which generically blend science fiction, fantasy, weird fiction, and Westerns, describe plenty of gun-slinging violence stereotypical of a genre very much grounded in a real place (the American southwest) but here set on distant, invented planets. This 
weird dislocation casts a critical light on the romanticized Wild West, leading readers to consider why such violence was prevalent in America's history of westward expansion, and moreover, why the Western genre was so popular during its heyday in the mid-twentieth century. The real American West and the Western genre both contribute to national myths which, I suggest, are reexamined by these British authors in the new millennium in response to George W. Bush's “cowboy"-style administration.

Western-themed mythscapes in these New Weird texts simultaneously glorify and critique elements of the mythical Western, while estranging the violence which characterizes the West. Raule from The Etched City and Judah from Iron Council pursue progressive goals which contrast with the typical themes of the Western: Raule renounces her former life as a failed revolutionary and becomes a pacifist and a healer, while Judah struggles to bring a train loaded with militant "proletariats" to an oppressive capitalist city. Meanwhile, the violent elements usually associated with Westerns, in the form of inhospitable landscapes, desperate brigands, hostile natives, imperialist ventures into the frontier, and so forth become obstacles to the protagonists' personal goals. Use of Western tropes allows these authors to exploit the popularity of the genre, but their unconventional protagonists, alien settings, and intermingling of other marvelous genres subvert the very genre-specific markers that define the Western tradition.

Chapter Five, "The Surreal, Pornographic Worlds of Carter and Acker," draws connections between two radical novels from the 1970s-Angela Carter's The Infernal Desire Machines of Doctor Hoffman (1972) and Kathy Acker's Blood and Guts in High School (1978) - and the Surrealists of the 1920s. Though the Surrealists had a reputation for misogyny, Angela Carter and Kathy Acker find subversive potential in their shocking, sexually explicit styles. The novels feature sexual imagery which is also disturbingly violent: the fictions 
construct nightmarish worlds in which male characters routinely damage female characters (and at times other men) through their sexual excesses. The authors' use of erotic imagery, absurd situations, and dreamlike environments mimics Surrealist art, reclaiming this movement for feminist purposes while violently distorting conventions of typical romance novels.

The protagonist of The Infernal Desire Machines of Doctor Hoffman, Desiderio, travels from his home city to defeat Dr. Hoffman and restore normalcy; along the way, this lustful man meets strange cultures and characters, most of whom engage in aberrantly sexual and violent acts. Because what we witness through the protagonist's point of view may also be a construct of his own wishes or fears (thanks to the Machines), the lines between desire and reality, victim and victimizer, truth and fantasy are endlessly blurred. Carter interrogates the dialectic between these concepts in our mundane reality through her intensely imagined, literary mythscape. In Blood and Guts in High School, Acker vehemently attacks the patriarchal structures in everything from the education system to the American presidency. The "notebook" style of the novel, which is a collection of sketches, dialogues, prose narration, poetry, and so forth, constructs a surreal space which embodies the tormented mind of a headstrong, abused girl. The protagonist, Janey, is constantly torn between her need to be loved by men and her desire to reject the man's world altogether. She is often ardently complicit in her own abasement, suggesting that gender relations are contingent upon a complex interplay of culturally conditioned roles. These novels of surrealist erotica overturn clichés of romance fiction by building worlds in which traditional gender roles are suspect and sex is frequently aberrant and violent, and never safe and "normal." Chapter Six, "Mythscapes in Post-Millennial Culture," lists how twenty-first century culture continues to use mythscapes to construct real-world arguments. Ideologues on both sides of the political spectrum rely at times on unreal, imagined spaces to promote their agendas. 
Proponents of global warming imagine a future in which rising temperatures endanger all of life by flooding, hurricanes, drought, and ecological catastrophe. Though it is based in scientific evidence, global warming rhetoric relies upon the eschatological imagination which similarly characterizes science fictional apocalypses and end-times paranoia. On the other side of the apocalyptic coin, fundamentalist religions continue to foresee Armageddon in our imminent future, and even some elected officials, particularly in the United States, put dangerous faith in such predictions.

Technological advances will progressively enhance the experience of imagining mythscapes. Digital rendering of 3-D environments, from the war-ravaged landscape of the Washington, D.C. area depicted in the video game Fallout 3 to the intergalactic conflict between military industrialism and benevolent indigenes depicted in the film Avatar, makes immersion in a mythscape a virtual reality. The internet can conjure virtual environments anywhere in the world immediately, infinitely; indeed, even a term like "internet" imagines a global web which does not exist materially, but only as a metaphorical concept. Globalization, too, is a concept which imagines the world not as it is, fractured, diverse, and subject to conflicting versions of progress, but rather promulgates a teleology of unity under the banner of pervasive American capitalism. Mythscapes continue to influence people as we strive to envision the world as it could be, even at the cost of obscuring what it is.

\footnotetext{
${ }^{1}$ Science fiction author Pamela Sargent describes how writing a historical novel caused her to be "constrained by the facts of history," and unlike speculative fiction, she could not "blatantly violate actual historical events" (par. 23).

${ }^{2}$ See Tuan $85-86$.

${ }^{3}$ See Freedman 106-111.

${ }^{4} \mathrm{Cf}$. Mendlesohn's concept of the "intrusion fantasy," 114-181.
} 


\section{Chapter 2: From the Ruins of the Post-Apocalyptic Feminist Novel}

The apocalyptic scenario is one of the most heavy-handed but deeply frightening worldbuilding techniques in speculative fiction. Lawrence Buell declares, "Apocalypse is the single most powerful master metaphor that the contemporary environmental imagination has at its disposal" (285). Post-apocalyptic fiction manipulates this “master metaphor" to construct mythscapes in the ruined future that reflect the author's perception of the trajectory of modern civilization. Radical feminist authors have experimented with the post-apocalyptic setting because it provides a fictional space in which to tear down the patriarchal civilization and build the world anew. Certain apocalyptic elements appear in four postmodern novels, Angela Carter's Heroes and Villains (1969), Doris Lessing's Memoirs of a Survivor (1974), Octavia Butler's Parable of the Sower (1993), and Jeanette Winterson's The Stone Gods (2007). All four novels construct what I call post-apocalyptic feminist settings, futuristic mythscapes in which the patriarchal civilization has failed, and the survivors pursue innovative approaches to recreate a better society. By responding to real contemporary issues, each novel also reveals how harmful ideologies and practices persist even in the ruins of the old world, a strategy that calls upon readers to begin the imaginative work of building a more just world.

A work of fiction set in the aftermath of a world-shattering catastrophe necessitates the construction of a rhetorical space that permeates the entire text. All major elements of the fiction are affected by the post-apocalyptic setting: "[T]he dystopian and post-apocalyptic texts tend to assert a setting that is more powerful than its characters, the landscape at least as much the subject as the people" (Rosenfeld 46) — at least initially. In the feminist post-apocalyptic, the protagonist often seeks to transcend the difficulties of the setting by forming a moral community whose struggles become pivotal as the narrative progresses. The author's choices of how the 
apocalypse arises and what remains are the foundations of the post-apocalyptic rhetoric. Some authors, like Carter and Winterson, imagine civilization's destruction as a sudden act of violence; others, like Lessing and Butler, posit a vague, gradual downfall that has brought modern civilization to ruin. In either case, this setting type fundamentally challenges existing hierarchies. Yet the elements of the post-apocalyptic setting may also present deeply rooted tendencies, such as masculine aggression, as so ingrained in humankind that even Armageddon cannot eliminate them. Douglas Robinson recognizes that the apocalyptic mindset "is an ideology very much concerned with the end of old eras and the beginning of new eras" (2), and as such, the direction of the "new era" is essential to the author's rhetoric: if an institution, concept, or culture can survive the Blast, it could either be an enduring value or an indelible vice. These novels describe the horrors of apocalypse not to terrorize readers into knee-jerk reactions but to speculate on alternatives, because unlike much end-times rhetoric, the novel form and feminist ideals are conducive to depicting problematic social conditions in all their complexity.

Utter annihilation of the planet or its people does not make for a feasible setting for fiction since something must remain for a novelist to write about. Thus, post-apocalyptic novels tend to be perversely optimistic about humankind's tenacity despite the destruction of contemporary civilization. Mark Decker writes, "A politicized dystopia would need to have utopian potential in order for it to motivate people to political action. After all, convincing people that they are doomed no matter what they do will probably not get them to turn out at the polls" (61). Many writers in the post-apocalyptic vein use that space as a means of determining which, if any, virtues are capable of enduring. David Buehrer observes, "[H]uman virtues can survive the 'blast'... subsurface feeling can incubate in and be unearthed from the fallout ashes, [and] the resources for self-renewal, contrary to the inevitablist theories," are again available 
(16). The humans that emerge from the ashes of a fallen civilization are, primarily, survivors. Jean Baudrillard also alludes to the orgiastic potential of massive destruction: "Because an explosion is always a promise, it is our hope... [T]he whole world waits for something to blow up, for destruction to announce itself and remove us from this unnameable panic" (55). It is a desperate optimism that sees hope in such destruction, but it is refreshing, perhaps, to envision what it's like to start over. This vision guides the construction of post-apocalyptic settings in fiction.

Throughout the twentieth century and into the twenty-first, many radical feminist writers have expressed their dissatisfaction with patriarchal civilization by evoking apocalyptic visions. In her anti-war essay Three Guineas (1938), Virginia Woolf harnesses the apocalyptic mindset when she envisions the incineration of man's educational institutions: "[B]urn the college to the ground. Set fire to the old hypocrisies....And let the daughters of educated men dance round the fire and heap armful upon armful of dead leaves upon the flames. And let their mothers lean from the upper windows and cry, 'Let it blaze! Let it blaze! For we have done with this 'education'!"' (36). In this moment, Woolf profoundly rejects the institutions which have marginalized women and aided in the academic ascendancy of patriarchal principles. In a more extremist mode of speculation, Valerie Solanas's SCUM Manifesto (1967) voices an enraged frustration at male-dominated society: "Life in this society being, at best, an utter bore and no aspect of society being at all relevant to women, there remains to civic-minded, responsible, thrill-seeking females only to overthrow the government, eliminate the money system, institute complete automation, and destroy the male sex" (qtd. in Third 105). This quote reflects the core theme underlying feminist post-apocalyptic space: the patriarchy is fundamentally unjust, and the best solution is to tear it all down and start from scratch. 
Angela Carter also speculates on apocalypse as retribution, decrying the foolishness of the arms race and her frustration with ineffectual, rational arguments against the Bomb in her contribution to a collection entitled Over our Dead Bodies: Women Against the Bomb (1983). She caustically observes, "We live in a country where a good number of British citizens may not sleep easy in their beds due to the murderous activities of white racist thugs and it might even be possible to argue that such a country deserves the visitation of fire from heaven" (Shaking a Leg, 45). Though she, like Woolf (and unlike Solanas), is not actually advocating such violence, she contemplates it as a drastic solution to seemingly ineradicable social problems. Mary Daly describes the issue of nuclear war as a masculine folly: "The explosions of nuclear weapons are also supernatural/artificial emissions—attempts of impotent males to connect eternally with their omnipotent killer-god" (340). Consider, also, the racially-charged apocalyptic language Gloria Anzaldua deploys in Borderlands/La Frontera (1987): she looks forward to a day in the near or distant future when "the white laws and commerce and customs will rot in the deserts they've created, lie bleached," and she and other "Chicanos will walk by the crumbling ashes as we go about our business" (1030). She perceives the white male patriarchy being responsible for its own downfall, and in its place, a new era with (presumably) better values will then thrive. Each of these examples offers a vision, however brief, of a future space in which the present institutions have been annihilated.

Science fiction provides a medium for exploring this cleansed space without requiring the violence necessary to construct it materially; after all, as SF author Frederik Pohl points out, "[H]ow much better it is to attempt to work out the consequences of political change in a science fiction story than to play them out in the bloodier, harsher, and less-forgiving real world we live in" (16). Gwyneth Jones, an author of feminist post-apocalyptic science fiction, explains how 
this process is cathartic:

I noticed that the end of the world, the chance for a completely new start, attracted me for personal reasons. And I was not alone. Whatever complex of familial, genetic and historical factors made me into a socialist and a feminist, I had plenty of company in my dis-ease with the state of things as they are. Social discomfort, and specifically sexual discomfort, even seemed to be the motive force behind a very different kind of apocalyptic discourse, which had just attracted the attention of both feminists and science fiction writers. (par. 10)

Spoken at a 1997 seminar on the apocalypse held at the University of Oulu, Finland, these words summarize for an international audience the ways that science fiction writers channel frustration, anger, and yearning for change into a socially acceptable model.

If the current civilization is the place, using Michel de Certeau's term, controlled by the patriarchy, then, with the boldest tactical move imaginable, the radical feminist dismantles this place and constructs a new space in its stead. Such fictions enact what de Certeau claims is "the primary role of the story": to create a dramatic space or "a field that authorizes dangerous and contingent social actions" (125). These contingencies are often the author's response to alarming trends in her contemporary society, and the fictional future extrapolates on how they are inimical to a moral civilization. The ideology of the feminist post-apocalyptic mythscape is guided by several principles:

- At the root of the feminist post-apocalyptic approach is a fundamental frustration with the exclusionist, heterosexist institutions ossified into patriarchal civilization.

- The destruction of the patriarchal civilization of the past is induced by that civilization's own aggression and violence. 
- Relationships between people in the post-apocalyptic world test the essential and/or cultural characteristics of gender and race. These might be altered by apocalypse or persist thereafter.

- Humankind's relationship to the natural world is reassessed in the wake of humans' self-imposed downfall.

- There is hope after destruction; apocalypse is not the end but a chance for a new beginning.

It is fitting that this radical literary subgenre emerges from the 1960s. This decade witnessed the coalescence of environmental concerns, feminism, and science fiction. Adam Rome connects environmental concerns with the women's movement in this era, citing Rachel Carson's Silent Spring (1961) and the 1961 Women Strike for Peace events—which protested the nuclear arms race — as two key examples of this union (536). Indeed, Buell considers Carson's text one of the foundations of the radical environmentalist movement, claiming that "the book manifestly precipitated both immediate legislative action and organized environmental radicalism" (295). Carson's nonfiction writing is at times speculative, and thus similar to science fiction; further, her pronoun usage suggests a collusion between environmentalism and feminism, as Buell explains: “Woman is rarely, if ever, nature's adversary in Carson's work, but 'man' often is" (292). So from the outset of the decade, Carson's speculative nonfiction conjoined feminist ideals with concern over the planet's demise. At this time fiction writers in general also began articulating concerns about widespread annihilation (Dowling 97). In his survey of the science fiction written during the decades of the twentieth century, Roger Luckhurst explains how it was during the 1960s that feminism and science fiction came together to reinvigorate each other's discourses: "The social and political interventions of feminist 
activists were available to be rapidly transposed, on a different front, into ways of reconceiving popular genres like SF" (181). Thus, the 1960s provides a fertile climate for fiction that takes real political concerns - in this case, those of feminism and environmentalism—and speculates on the potential doom to come if these concerns are not addressed. Carter's novel was published as that decade drew to a close.

\section{Carter's Heroes and Villains}

Angela Carter's Heroes and Villains (1969) deploys the imaginative strategies of the postapocalyptic space by addressing growing concerns about nuclear holocaust, suburban sprawl, and, most importantly, the patriarchy's aggressive, anthropocentric dominion over the world. Marianne, the protagonist, leaves her father's compound to roam the verdant wilderness with the nomadic Barbarians. She falls in love with a Barbarian named Jewel, who struggles to control their tribe but is antagonized by his adoptive father, Donally. Though Marianne yearns for conjugal bliss in isolation with her lover, Jewel's pride as leader of their people and battles with

the mutant Out People prevent this. When Jewel dies, Marianne grimly takes on the leadership of their tribe.

The novel is set in an indeterminate future following a devastating war. The narrator gives cryptic clues about the apocalypse that shattered modern civilization- - "The war," "the fire," and "the blast" are seemingly synonymous and hint strongly at nuclear holocaust. The reader learns that "cities" as we know them do not exist when Marianne is asked, "what does the word "city" mean?", and she tentatively responds, "Ruins?" (Carter 7). City no longer signifies what it once did because words used to label elements of civilization "had ceased to describe facts and now stood only for ideas or memories" (7). Leonard Lutwack describes how ruins operate 
symbolically in fiction: "Ruins continue the influence of the past on the present as either monition or model" (55), and they are "strategic places" of critical import that "testify to the folly of the past rather than to its greatness or awesomeness" (56). Rather than appearing simply as nameless markers of a bygone era, as they do to Marianne, ruins act as critical warnings to the reader, who recognizes that present-day structures may be tomorrow's rubble if the trajectory of the present is not altered. For the feminist post-apocalyptic, they are reminders that the oppressive institutions of the present are impermanent.

Outside the fortified compounds wherein Marianne's story begins, she learns firsthand what remains after the apocalypse. In place of a sprawling suburbia, Marianne discovers "shells of houses [that] now formed a dangerous network of caves, all so overgrown it seemed nothing could ever have lived there" (8). The defeat of industrialized civilization means a resurgence of nature. But this is less a tragedy than an idyllic pastoral, as when Marianne enters a wilderness where everything is "green or else covered with flowers" in "a wholly new and vegetable world" (22). Lutwack describes this common trope in post-apocalyptic fiction: "[T]he decay of civilization may be effectively symbolized by the recrudescence of vegetation in civilized places, especially within houses and cities.... A favorite touch in twentieth-century apocalyptic fiction is the encroachment of vegetation on the scene of the most advanced civilization, the city" (50). Nothing indicates the defeat of civilization more than the regrowth of plant life inside the metropolis, a radical reversal of "mankind's" battle to overcome the wilderness since ancient times.

In the ruins of civilization, human communities are separated into subcultures of Professors, Barbarians, and Out People. Marianne's father, a Professor, explains that the different groups are actually distinct species, including Homo faber, Homo praedatrix, and 
Homo silvestris (Carter 9). The struggle among these groups represents a new competition for the top of the evolutionary ladder because, as Dowling notes, the post-nuclear "society becomes rigid or must fight against other societies which represent different phases of evolution" (90). Furthermore, this tri-partite classification grotesquely reflects the modern world's class system, especially the distinction between so-called first and third world peoples. Its culturallyconstructed condition becomes clear when Marianne later moves easily between groups.

When Marianne's father describes his caste, it is apparent that the Professors are the dying remnants of the elitist patriarchy: "Before the war, there were places called Universities where men did nothing but read books and conduct experiments. These men had certain privileges, though mostly unstated ones" (Carter 8).. All their powerful institutions are but memories now, and their formerly grand schemes are but shadows. Since the narration begins in the compound run by the Professors, this insular culture is initially the familiar ground that readers can readily identify with—even if, like the protagonist, they are not satisfied with it. Marianne rejects this stodgy society of the Professors when she runs away with the Barbarians.

In contrast to the Professors, the Barbarians "seem to be caught in the moment of transition from the needs of sheer survival to the myth-ruled society, defined as existing outside history,” as Eva Karpinski recognizes (140). Yet even this culture is patriarchal, dominated by strong, charismatic men like Jewel and Donally. Further descriptions of these people as a group disclose a curious comparison: some Barbarians "wore Soldiers' jackets" in which "the black leather had been transformed by the application of beads, braiding, and feathers"; others had hair "wound with ribbons and feathers; their faces were painted a little round the eyes or else tattooed with serpentine lines"; and "[m] ost were barefoot, though some wore stolen boots or sandals made of straw" (Carter 13). Their fashions recall the counterculture movement of Carter's era, 
and so these Barbarians could represent the counterculture to the elitist Professors. Further, Marianne's decision to leave with the Barbarians corresponds to the 1960s trope of the youth rejecting her parents' lifestyle to pursue her own destiny. Because the Barbarians' struggles form the central conflict of the text, they provide an uncanny but obvious touchstone for the youth movement contemporaneous with the novel's publication.

While the Professors and Barbarians have precedents in recognizable contemporary subcultures, the Out People "confound the boundaries between human and nonhuman as well as those between the sexes" (Karpinksi 141). Each Out Person has his own unique and monstrous deformities, so as a whole they lack the appearance of cultural unity maintained by the other two groups. Their deformities suggest that they have mutated due to nuclear radiation; they are the tragic victims of the apocalyptic blast that precedes and grounds the novel's action. Dowling perceives nuclear radiation as speculatively positive simply because it guarantees new evolutionary patterns — he envisions the "fantastical futures" made possible by nuclear catastrophe, "particularly when one considers the potential in nuclear explosion for subsequent mutation of organic life" (Dowling 86). The Out People also provide an ideological advantage in this sense. Though brutal and monstrous, traditional gender distinctions hold much less weight amongst so many inhuman deformities. Perhaps it's not so ironic, then, when Marianne momentarily considers becoming a so-called Out Person (Carter 137).

While the people are classified in these species-groups, the natural world's recrudescence allows animals and plants to transcend human nomenclature. When the alpha-male struggles amongst the motley Barbarian culture become too frustrating, Marianne and Jewel briefly withdraw on their own to the seashore. Seeing many new and strange organisms there, Marianne realizes that she doesn't know their names, even "though everything had once been scrupulously 
named" (Carter 136). Without classificatory names, the wonders of nature take on a mysterious significance: "Losing their names, these things underwent a process of uncreation and reverted to chaos, existing only to themselves in an unstructured world where they were not formally acknowledged, becoming an ever-widening margin of undifferentiated and nameless matter surrounding the outposts of man" (136). Through these unnamed organisms, the novel constructs a pre-Edenic space, a paradise unsullied by the first man and his naming system which signifies his dominion over all others. Carter's language suggests they are physically transformed by their liberation from classification, similar to Mary Daly's assertion that "Naming is an invocation of Other reality" (xii). Marianne considers that if she and Jewel leave the Barbarian tribe, "they would become Out People and surrender to namelessness, if the worst came to worst; but at best, they might begin a new subspecies of man who would live in absolute privacy in secret caves, accompanied only by danger of death, imbibing a suitable indifference to the outside" (Carter 137). She imagines living with her husband and their future child in a heteronormative nuclear family, although separate from the patriarchal cultures of the Professors and Barbarians.

The epiphany proves fleeting, however. Jewel dies at the novel's sudden conclusion, ending the idyllic romance and reminding Marianne and the reader that the patriarchy's perennial aggression and control are not easily undone. Jewel's fate is all the more striking because it is foreshadowed by red herrings of natural death that seem eerily peaceful. First he attempts suicide by drowning in the sea, and then he has a close encounter with a predator: a lion wanders near Marianne and Jewel as they rest, but the animal is characterized as "prey to an infinite boredom" as it yawns over Jewel's sleeping form before slinking away (Carter 140). In this verdant world, nature does not threaten humanity. Instead Jewel's pride compels him to ride to battle, and his death occurs "off-stage" by a bullet when he confronts the men who challenge his control of the 
Barbarian tribe (Carter 150). Even from the ruins of the patriarchy's hegemony, masculine pride and aggression inevitably reassert themselves. Jewel's abrupt death signals the end of the narrative; nonetheless, the novel leaves the heroine's future open, not bound to the "happily ever after" of a heterosexual partnership as in traditional romances.

In spite of all that the novel does to highlight the errors of the past, the protagonist looks to the future with a determination that echoes the patterns of the patriarchy. One of Marianne's last lines in the novel is a response to the question of how she will rule her tribe in the absence of her male partner. She declares, "I'll be the tiger lady and rule them with a rod of iron" (150). Ironically, the phallic scepter and even the title "lady" suggest that, although the gender of the sovereign may have switched, the machinery of dominance has not. Carter's radicalism is tempered by the bitter concession that cultural change is obstructed by all the names and symbols that have controlled us in the past. She admits, "Perhaps the collective consciousness can expand only so much, and then the shift back to the known, the familiar, and the safe begins" (Shaking $a$ Leg, 156). Her novel suggests that even a radical break with the immediate past does not necessarily clear the slate for utopia. The cycle of destruction will not cease if the old institutions remain even after the buildings that housed them are reduced to rubble.

\section{Lessing's The Memoirs of a Survivor}

Unlike Heroes and Villains, wherein the protagonist has grown up in the post-apocalyptic world, the unnamed protagonist and narrator of Memoirs of a Survivor is older and can vaguely remember how the current scenario came into being. It occurred through a gradual downfall, in sharp contrast to "the Blast" which violently inaugurates many post-apocalyptic spaces. The protagonist is a middle-aged woman living alone in an apartment in a crumbling city. Her bleak 
life is complicated by the introduction of Emily, an adolescent girl who is inexplicably left in the protagonist's care. The novel chronicles the relationships between the protagonist, Emily, her strange pet Hugo, and Gerald, Emily's love-interest. These characters eke out an existence in the ruined city as it degrades further into barbarism, anarchy, and poverty. Unable to cope with life in the post-apocalyptic world, the narrator frequently escapes into a space "behind the wall." At first this space seems hallucinatory, but when she begins to divine her young charge's past and imagines an idyllic future there, it becomes a portal through which the main characters escape from the ruined world.

Describing the fall of civilization, the protagonist-narrator admits, "I can't set down a date or a time," and "[T]here is nothing I can pinpoint, make definite..." (Lessing 7). This elliptical trailing-off is in the original text, and it points to the uncertainty of the narrator's recollection. Her uncertainty reveals that the narrator is not wholly reliable: her perspective as an aging observer essentially trapped within a small apartment limits her factual information about the world outside. Further, this unreliability complicates the reader's perception of the space "behind the wall," a fantastic setting-within-a-setting whose veracity is crucial to the novel's theme. While Carter's Marianne cannot rise above her post-apocalyptic setting, Lessing's embedded world allows her characters to fully transcend the place of the destroyed civilization. By controversially crossing from science fiction to fantasy in its final pages, the novel disrupts the reader's genre expectations to act as a bold model of what Marleen Barr calls "feminist fabulation."

Embodied by the narrator's limited perspective, uncertainty is the dominant mood of the novel. The narrator describes how official news sources did not explain decay of civilization truthfully, but word of mouth soon revealed that there was "generalised unease" (4-5), a sense 
that "the ground was dissolving under our feet" (19). Here, the end comes about insidiously, creeping into everyday life so gradually that it is not perceptible by official reports. Aaron S. Rosenfeld is critical of the vagueness of the novel's exposition because the "indeterminacy of events - something has happened to break down the social fabric, but we do not know what or why_ - offers the dystopian/apocalyptic formula cleansed of one of its primary functions, that of warning" (49-50). However, I discern an implied warning that the downfall of civilization may not be something we can easily predict and therefore prevent. Because it is so vague and gradual, and because "generalized unease" and mistrust of authority are such recognizable features of postmodern culture, the reader cannot help but wonder if the deterioration of our present civilization is not already underway. Lessing makes the setup more familiar by addressing the reader directly (she is writing memoirs, after all), saying that "the reader should have no difficulty here: these words are a description of the times we have lived through" (18). Her narrative makes the post-apocalyptic more familiar by juxtaposing the devolved state with a recognizably modern one: "[A]ll over our cities — side by side with citizens who still used electric light, drew water, for which they had paid, from taps, expected their rubbish to be collected - were these houses which were as if the technological revolution had never occurred at all.... All over our city were these pockets of life reverting to the primitive" (Lessing 102-3). This is a chilling, disconcerting method of building the post-apocalyptic setting, but one that is eerily plausible, not incomprehensible like planetary destruction through nuclear war.

At times, the narrator reflects critically on the notions of progress that led the civilization to such a state. Musing on how space technology, artificial fabrics, and other accomplishments of humanity were once sources of pride, she admits, "[A]s we sit in the ruins of this variety of intelligence, it is hard to give it much value" (Lessing 81). But the narrator is pleased by how 
innovative the young people can be when forced to survive in such conditions. She watches Emily create outfits which are conglomerations of the fashions of the past and marvels "to see this creation at such a time of savagery and anarchy, this archetype of a girl's dress—or, rather, this composite of archetypes; the way this child, this little girl, had found the materials for her dreams in the rubbish heaps of our old civilisation... and in spite of everything had made her images of herself come to life" (57). The clothes Emily wears and the old fashions she renews are a recurring source of secret delight for the narrator, who regards Emily's eclectic outfits as explorations of her identity as she grows from a child to a woman. She even uses the word "chrysalis" to describe her clothing during maturation (Lessing 59), similar to Daly's concept of the "Metamorphosis of metapatriarchal women" (408), signifying how Emily transforms into a young woman and leader of the post-apocalyptic society. Emily's creativity and innovative spirit suit her well not only as a designer but as a matriarch in the tribal groups of young people who form organically in the ruins: "Emily and Gerald become leaders in the post-Catastrophe society because they are able to shuck off old assumptions, decadent habits of behavior, and outmoded social relationships and assist a new social system to develop" (Draine 55). The inventive youth in this ravaged city represent the hope for a better world characteristic of the feminist postapocalyptic space.

In addition to the primary post-apocalyptic setting, there is an inner world "beyond the wall," a sort of mental space to which the protagonist escapes and plays out seemingly real scenes from Emily's past and possible futures. Reminiscent of Charlotte Perkins Gilman's The Yellow Wallpaper (1892), the narrator stares at the sun's light on the wall of her apartment and has an out-of-body experience wherein she moves through the wall to imagined rooms beyond (Lessing 12). This inner world is a nested or embedded world, a world within a world described 
by Brian McHale. He explains that placing one setting inside another has "the effect of interrupting and complicating the ontological 'horizon' of the fiction, multiplying its worlds, and laying bare the process of world-construction" (112). To embed a space is disconcerting because it seems to violate the reader's assumptions about the unified structure of the author's world and the genre tropes used to construct it. In contrast to the decaying but recognizable place of the primary setting, this space is symbolic, composed of archetypes and prophetic visions. Betsy Draine describes the space beyond the wall as "set outside of time, space, and particular conditions. It is a world of archetypal figures (gardens, birds, leaves, flowers, magic carpets, goddesses) arranged so as to constitute a spiritual vision" (55-56).

Indeed, the apparent veracity of the narrator's visions behind the wall is nothing short of fantastic; after one such vision, the narrator attempts to rationalize "that I had been watching a scene from [Emily's] childhood (but that was impossible, of course, since no such childhood existed these days; it was obsolete): a scene, then, from her memory, or her history, which had formed her" (Lessing 45). The space behind the wall changes with each visit, and each time, the narrator gleans some insight into Emily's supposed past, particularly her difficult relationship with her indifferent mother. As the situation in the primary setting becomes more dire, she begins to envision "another world, not ours" beyond the wall, which is idyllic and pastoral: "Gardens beneath gardens, gardens above gardens: the food-giving surfaces of the earth doubled, trebled, endless" (Lessing 158). She has transitioned from having intuitive sequences about her young charge's past and into full-blown fantasies of a utopia beyond the wall.

Because the narrative act of embedding a world "serves as a tool for exploring issues of narrative authority, reliability and unreliability" (McHale 113), it is not exactly clear whether the narrator's insights "behind the wall" are hallucinations or genuinely enhanced perceptions. I 
would argue the latter because the enhancement of woman's powers of empathy occurs in other works of feminist science fiction, such as Sally Miller Gearhart's The Wanderground (1979), Elizabeth Hand's Winterlong (1990), and Octavia Butler's Parable of the Sower (described below). Such common features suggest that an advantage of nonmimetic fiction involves the potential for expanding on the positive (if stereotyped) traits of femininity. These enhanced perceptions parallel Daly's concept of "Elemental female Lust", which is "forseeing, foretelling, forecasting" and senses "the Sources, Astral Forces, Angels and Graces that call from the Deep" (3). Part of radical feminism's concept of female empowerment involves harnessing the intuitive strengths of Woman, so to interpret Lessing's protagonist as merely delusional would undermine these feminist tropes — tantamount to a psychologist dismissing a female patient for being "hysterical." She may have hallucinations, initially, but they are intuitively accurate about the reality around her.

Furthermore, Lessing's narrator experiences positive sensations behind the wall, not anxiety-inducing delusions. She claims, "[I]t was always a liberation to step away from my 'real' life into this other place, so full of possibilities, of alternatives" (Lessing 64). This description mirrors Marleen Barr's concept of feminist fabulation, which constructs a "place of fabulative feminist potential, a place which might present us with anything" (17). Rather than disdaining the shift to what some might call "genre fiction," as Cederstrom, Draine, and others have done, Barr perceives Lessing's controversial venture into science fiction as a ground-breaking model that could encourage other "feminist fabulators" to follow suit (17). Thus the novel breaks away from the science-fictional vein to construct a wholly fantastic world which does not (yet) exist, in much the same way that feminist post-apocalyptic fiction imagines the shattering of civilization as a liberation from the self-destructive hegemony built by men. 
The distinction between the alleged real world of the novel and the unreal world behind the wall is disrupted further at the novel's conclusion, when Emily, Gerald, and Hugo physically follow the protagonist into the hallucinatory world (212-213). Draine is critical of this scene because it breaks the continuity of the novel: while initially the space "behind the wall" had been internal for the narrator, it is now inexplicably accessible to the others; she calls this move "a repudiation of the text as a whole" because it stretches the reader's capacity for accepting either fictional space as "real" (57). From the standpoint of genre tropes, this final scene blurs the distinction between science fiction and fantasy, because with the former, what is possible is based on extrapolation of the real world; however, walking through a portal to a place where "Eden is at last recovered and the characters euphorically submit themselves to the long-lost protection of the mother-goddess" (Draine 57) is a definitive step towards the fantastic, which need not be extrapolated from rational connections to our world.

Because the narrative ends when they step through the portal, the key thematic concern is how this imaginative leap is to be interpreted by the reader in relation to the conflicts within the primary setting. Metafictionally, the presence of the hallucinatory space behind the wall becomes a postmodern critique of the act of reading, wherein the reader pictures a fictional space in her mind which is every bit as "real" as the secret space the narrator seems to enter. For the reader, both settings create mental spaces which are equally abstract because "an act of reading is the space produced by the practice of a particular place" (de Certeau 117). But while the reader's engagement with the text may not differ between the two mental spaces, their effects on the postapocalyptic feminist rhetoric are distinctly different. "In moving from the world of material reality to the world of imagination and vision, Lessing has moved from Marx to Jung" (Draine 56); likewise, while the futuristic, science-fictional space is allegedly grounded in the realities of 
the material world like Marxism, the fantastic space is one that vivifies Jung's archetypal notions about legends and ideals. Moving behind the wall effectively signals the shift from science fiction to fantasy, and the latter allows the author finally to sever all ties with the contemporary world. Farah Mendlesohn provides a fitting description of the distinction between these genres: "Fantasy, unlike science fiction, relies on a moral universe: it is less an argument with the universe than a sermon on the way things should be, a belief that the universe should yield to moral precepts" (5). Hence, when Lessing's characters follow the now-matriarchal protagonist into the fantastic space beyond the wall, the novel is finally constructing the world as it should be, a world both Carter and Lessing attempt to create in the aftermath of apocalypse but are limited from achieving by the lingering shadows of the patriarchy.

This move serves the feminist post-apocalyptic by liberating the characters from such tenacious connections. By the conclusion, life in the bleak city has become increasingly unbearable: feral children rove in packs and behave in "every way worse than animals" (Lessing 177); new diseases begin ravaging the ignorant population (153); the air becomes "impossible to breathe" (188); even the tenuous tribal groups organized by Gerald and Emily are no longer viable (198). The narrator despairs when "thinking how very near we were to running and scurrying like rats along tunnels" (194). Most importantly, the narrator seems to recognize that "the old arguments" will not work in the complete anarchy that is to come, and ultimately, even the innovative youth are left only re-hashing the old paradigms (176), just as Emily, in spite of her sartorial creativity in forming her identity, was merely clothing herself in a patchwork of old designs. The solution, then, is to escape from the primary world completely by entering the nested world behind the wall.

The novel's conclusion has the temerity to illustrate what Barr wishes for all feminist 
fabulation:

As inhabiters of this alternative reality, like Emily's transmuted self, women can move beyond their present selves, can become splendid, dignified selves.

Feminists can theorize about dissolving walls which imprison women within a sexist reality they_-with few exceptions - have not made. Readers, fiction writers, and theorists can begin to construct new feminist paradigms, viable feminist futures. (18)

Lessing's notable contribution to the feminist post-apocalyptic canon is her unique manipulation of the post-catastrophic space: inserting the fantastic, nested world within the mythscape lets the novel transcend genre boundaries and act as a model for reconceiving feminist potential while at the same time providing a postmodern commentary on the real, the fictional, and the reader's potential relationship to both.

\section{Butler's Parable of the Sower}

Like Lessing's novel, Octavia Butler's Parable of the Sower describes a post-apocalyptic space that results from the gradual decay of the social order, not through a violent blast. But in contrast to the previous two novels, Butler's fiction is set in a precise time and place-California in the year 2024. Her novel takes the form of journal entries written by the protagonist, Lauren Olamina, a young black woman who has "hyperempathy," a condition of heightened perception that forces her to feel the pain of others. Lauren begins the narrative within the walled compound which her family shares with several other families. Outside the compound, chaos rules: corrupt police are impotent to stop roving hordes who rob, rape, commit arson, and murder. Lauren describes in her journals how the mob violence encroaches on their "safe" community. First her 
brother is killed, then her father vanishes. Finally the barbaric horde raids her compound, and Lauren is forced to flee with two other survivors, Harry and Zahra. They make their way north and gather other benevolent individuals along the way (notably Bankole, an older gentleman with whom Lauren establishes a relationship), to found a safer community. Lauren is guided by the religion she has invented, Earthseed, whose central tenet is "God is change." At the novel's conclusion, the cabal arrives at Bankole's land in rural Humboldt County, California. There they begin the arduous task of building a compound for their new community.

Because Butler describes real locations and her novel is set in a very near future, its connections to the present seem more substantial, as Stillman recognizes (15). The notion of a speculative future as a warning to the present is, of course, not new to science fiction studies, but it is vital to understanding the genre's potential for social critique. Carl Freedman explains, "The future is crucial to science fiction not as a specific chronological register, but as a locus of radical alterity to the mundane status quo, which is thus estranged and historicized as the concrete past of potential future" (Freedman 55, emphasis in original). In short, extrapolations of the speculative future should be contingent on actual history to have critical potential. My reading of Parable of the Sower is inflected by two major elements of the socio-political scene of the "concrete past": the neoconservative agenda of minimal government (as explained in an essay by Peter G. Stillman), and the 1992 riots in Los Angeles following the Rodney King verdict. The dialectic between these two late-twentieth century phenomena infuse the novel with urgency and exemplify how the feminist post-apocalyptic setting is directly grounded in the author's contemporary concerns. Butler's novel suggests that a moral society can only re-emerge through heightened empathy, a trope of feminist speculative fiction, and communal solidarity, a core theme of feminist post-apocalyptic fiction. 
Peter G. Stillman argues that the novel posits a future in which government deregulation has been all but realized (17). He explains that this political agenda has led to the downfall of social order in the United States by increasing the gap between the rich and poor and ignoring almost all human rights and environmental protections (17). Though Stillman does make passing reference to the riots following the Rodney King verdict in 1992 in his analysis of the novel (n.6, 33), he foregrounds the Republican agenda of privatization and less government as the impetus for Butler's dystopian imaginings. While this argument has fruitfully informed my interpretation of the text, it places the burden of civilization's downfall solely on the shoulders of contemporary Republicans and downplays the choices an individual must make when in such a troubled society. Certainly the novel insinuates a critique of late-twentieth century neoconservative politics; but as Stillman admits, "Octavia Butler does not give her readers easy answers" (Stillman 30).

I contend that the anarchy and violence of the Los Angeles riots also play an important role because descriptions of the masses' behavior in the novel (published in 1993) parallel descriptions of real-world violence during the 1992 riots. Unlike dystopian novels such as George Orwell's Nineteen Eighty-Four (1949) or Winterson's The Stone Gods in which the oppressive government is the enemy, in Parable of the Sower, roving gangs are the dangerous antagonists. This suggests that humans have an innate propensity for violence and selfishness when unchecked by a strong moral government. But while anti-government politics may have created the lawless conditions necessary for a state of constant rioting, the individual still has an important choice in this dystopia: to recognize his or her obligations to family and community, or to embrace sociopathic opportunism. Butler's novel demonstrates this dilemma through the juxtaposition of Lauren and her brother Keith. Lauren understands that an individual with a 
strong moral compass can gather like-minded people to sustain a just and prosperous community, while Keith pursues a doomed course of personal gain at the expense of the weak.

Butler has a strong reputation for deploying the science fiction genre as a vehicle for realworld social critique. According to Jim Miller, Butler states that "her sources were her life in the Los Angeles area and news in general" (358, n.3). Gang violence, drug addiction, class inequalities, and so forth were causes of conflict in California in the 1990s that appear in the novel. The L.A. riots of 1992 were also making world headlines during the time when the novel was being written. But by writing a science-fictional mythscape instead of mimetic literature, "Butler utilizes a range of literary techniques, including dystopian extrapolation and defamiliarization, to work against the prevailing discourses that numb readers to the realities of the contemporary world" (Lacey 386-7). She confronts the reader with the idea that the L.A. riots are not merely an ugly moment in the past but a symptom of the ongoing societal downfall in America in the millennial age.

In descriptions of the Los Angeles riots in late April, 1992, arson was a common occurrence: "After nightfall, more crowds gathered at police headquarters and City Hall, where they set a small fire in the lobby. Throughout the afternoon and into the night, young men in south-central Los Angeles smashed storefronts, set fire to shops and vehicles and pulled motorists from their cars and beat them. There were about 120 separate blazes, the Fire Department said" (Mydans 1). Another reporter describes how "[p]rotesters laid siege to federal and state buildings, tossing petrol bombs through the windows. Flights into and out of the city's airport were rerouted because of black smoke drifting across the area" (Passmore 1). Butler's novel depicts a future in which arson is a perpetual hazard. A news station displays "whole blocks of boarded up buildings burning in Los Angeles," a scene apparently so commonplace 
that "no one would waste water trying to put such fires out" (Butler 16). In a passage that could just as aptly describe the L.A. rioters, Lauren decides that "[p]eople are setting figures because they're frustrated, angry, hopeless. They have no power to improve their lives, but they have the power to make others even more miserable" (Butler 128). The proliferation of arson is at least partially attributable to a new drug called "pyro" that compels uses to start fires and stare at the flames. Jim Miller writes that the drug "seems to be a comment on the self-destructive cycle of crime and drug addiction in the inner city" (350). Since the drug makes arson "better than sex," (Butler 47), it replaces the primal urge to procreate with an addiction to violent destruction. Such a drug is hyperbolic example of how the individual's choice to abuse drugs directly damages the community.

Individual instances of violence are compounded in the novel so that violence is just part of the setting, an uneasy backdrop that constantly threatens peace and stability: "We hear so much gunfire, day and night, single shots and odd bursts of automatic weapons fire, even occasional blasts from heavy artillery or explosions from grenades or bigger bombs" (Butler 44). Again, an actual description of the L.A. riots could be an elaboration of this generalized violence from another angle: "Armed gangs, hundreds strong, roamed loose, looting stores, torching as many as 150 buildings and ambushing motorists. The authorities reported 138 people injured" (Passmore 1). The violence in April of 1992 is inextricable with racial issues, a claim most boldly dramatized by Anna Deveare Smith's one-woman play, Twilight: Los Angeles, 1992 (1994), in which the author impersonates men and women of diverse races who were affected by the riots. In the persona of Maxine Waters, a Congresswoman from California, Smith declares that "riot is the voice of the unheard" (1745). But riots are also dangerous forces that often target the weak rather than fix the system, as when the victims of 1992's riots included Korean citizens 
and other innocents in the local community (Miller, Abraham 196). Such riots might stem from protests against injustice, but unlike marches, sit-ins, and other forms of dissent, riots quickly devolve into generalized destruction that does not discriminate between the guilty and innocent. By evoking the imagery of the riots, Butler's novel compels the reader to imagine a state of constant rioting, one perhaps fomented by social injustice but perpetuated by fear and aggression, and to consider how one can act morally when neither the government nor the people do so.

Lauren is thus exemplary because she refuses to join the mob, but she also rejects the reactionary impulse to revert to a time before the rioting, recognizing that past injustices led to the current state of anarchy. As she reflects on the destruction of their formerly safe compound, Lauren admits, "I didn't believe we would be allowed to sit behind our walls, looking clean and fat and rich to the hungry, thirsty, homeless, jobless, filthy people outside" (Butler 167). This passage is particularly incisive to $21^{\text {st }}$ century Americans, whose status as the wealthiest citizens in the global schema has garnered them much antagonism from poorer nations. Class is another distinction of late-capitalist society that will reinforce rifts between its people: "In 2024, patterns of race and class dominance have hardened to the point where they have genocidal implications_-others are those I must kill” (Phillips 305). Some better-off people even go so far as to make themselves appear dirty to avoid being targets (Butler 16). In the outside, "otherness" can be fatal, whether it is biological or cosmetic.

Being female also makes one a target, which is why Lauren disguises herself as a man when she travels north. Differences between gender are crucial to understanding what went wrong with the culture and how to avoid the same mistakes in the future, especially in the context of the feminist post-apocalyptic. Lauren's father, Reverend Olamina, is a foil to the 
narrator whose fate is telling. The elder Olamina shares some important traits with his daughter. Both are strong-willed, charismatic, and religious: the Reverend is a Baptist preacher, professor, and community leader. But the Reverend's key difference from his daughter is his stubbornness (Butler 82). This also is his fatal flaw because he refuses to move his family from the compound and seek a new life elsewhere, despite the pleas of his daughter and his wife. Then one day he leaves for work and never returns, and shortly thereafter, their compound is raided and destroyed. While the Reverend's Christian God is the traditional omniscient Father of commandments, rewards, and punishments, in Lauren's Earthseed religion, “God is PliableTrickster, Teacher, Chaos, Clay. God exists to be shaped. God is Change" (Butler 22). Her faith in this Earthseed God is thus an acknowledgement of the necessity of adaptation, and this trait ensures Lauren's survival when she must flee the compound and start anew.

Keith, Lauren's younger half-brother, is another important foil to the narrator, and their fundamental differences are crucial to the novel's theme. When he is ordered by his father to stay within the compound and not venture out on his own, Keith shouts, “I'm a man! I shouldn't be hiding in the house, hiding in the wall; I'm a man!"” (Butler 82). His masculine prerogative to be independent, coupled with his stubbornness (Butler 82) and his father's harsh discipline, make Keith's departure from the compound inevitable. Shortly before he dies, Keith returns to the compound and reveals an important fact about the world outside to his sister: "'If you got a gun, you're somebody. If you don't, you're shit'" (96). It is true that guns are important to defend oneself in Butler's dystopia. But Keith's attitude seems to echo Elaine Brown's sentiments on the futility of gun violence for its own sake: "I think that this idea of picking up the gun and going into the street without a plan and without any more rhyme or reason than rage is bizarre and...foolish" (qtd. in Smith 1750). Had Keith stayed at home in the compound, he might have 
been able to help protect the community, as Lauren does. Both Lauren and Keith's mother Cory beg Keith to stay home, but he opts to pursue the path to quick and dirty profits, at least partially because of his conception of his culture's stereotypes about masculinity.

Lauren learns from her father's and her brother's fates, realizing that to be defenseless and alone in this world is to invite death or worse. So her own goal of survival is coupled with an awareness of the importance of community—one that must be defended by force. Lauren and her father's views on guns for protection echo Brown's declaration that "if you want to effect change for your people and you are serious about it, that doesn't mean throw down your gun" (qtd. in Smith 1750). Lauren's new community takes the knowledge she learned from her father's leadership example — which involved sharing responsibilities, looking out for one another, learning to defend from outsiders, etc. - and adds to it her self-discovered knowledge of Earthseed and her hyperempathy. The protagonist is in a unique position as leader because she can feel the pain of others. This ensures that she must always act with others' interests in mind. "Butler's ideal society, it would seem, is one in which the relationship between the individual and the larger society is reciprocal and mutually enriching” (Miller, Jim 347). Lauren expounds on the social benefits of hyperempathy syndrome, asking, "[I]f everyone could feel everyone else's pain, who would torture? Who would cause anyone unnecessary pain? ... I wish I could give it to people. Failing that, I wish I could find other people who have it, and live among them. A biological conscience is better than no conscience at all" (Butler 102).

Parable of the Sower ends with the founding of a utopian society whose tribulations are dramatized later in the series. The promise of a new beginning is central to the feminist postapocalyptic space, and Lauren's new community is optimistically named Acorn to symbolize this promise. Despite its speculative setting, though, the novel is truly grounded in the present. This 
is exemplified by the connections to the Los Angeles riots, implicit critiques of neoconservative agendas, and lingering class/race/gender issues of late twentieth century America. The urgency of acting now is reinforced by passages in the text which could be warnings to the reader. For example, Lauren urges her friend to "[g]et ready for what's going to happen, get ready to survive it, get ready to make a life afterward. Get focused on arranging to survive so that we can do more than just get batted around by crazy people, desperate people, thugs, and leaders who don't know what they're doing!" (Butler 48). This could just as easily be Butler speaking to the reader in 1993 or 2010. Likewise, near the novel's conclusion, Bankole, Lauren's lover, laments, "I wish you could have known this country when it was still salvageable" (294). This simple desire represents Butler's legacy to the reader, who does know this country when it is not past redemption and can act to prevent the decay of its civilization. But this can be accomplished only if the present course is averted through an emphasis on community rather than personal pride, cooperation rather than competition, and empathy rather than selfishness.

\section{Winterson's The Stone Gods}

Jeanette Winterson's The Stone Gods (2007) complicates the spatio-temporal construction of a feminist post-apocalyptic mythscape by featuring not one possible future, but rather describing the destruction of several interlaced settings and foregrounding the cyclic nature of apocalypse. The first section, "Planet Blue," is a science fictional tale about the discovery of the eponymous primeval world by the inhabitants of Orbus, a funhouse-mirror image of what could be our Earth in the not too distant future. The protagonist, Billie, joins an expeditionary force to Planet Blue that seeks to make it habitable for humans by annihilating the dinosaurs living there, triggering an apocalyptic ice age in the process and rendering the 
formerly-verdant planet hostile to most animal and human life. The second section, "Easter Island," is set in Earth's past in the year 1774, and it chronicles the deforestation of Easter Island by overzealous natives who cut down all the trees to make room for stone statues. The third section, "Post-3 War," is something of a prequel to "Planet Blue" in which Billie discusses the dismal situation of a world after the Third World War with her soon-to-be robot lover, Spike. The final section, "Wreck City," is perhaps closest to the conventional post-apocalyptic setting because it is set in a bombed-out city; from the ruins, Billie and Spike speculate on the causes of the apocalypse and the possibility of starting over on another planet.

The four sections are tied together not by a unifying plot but by recurring characters (a female Billie and a male Billy, a female robot Spike and a male Spikkers), and two core themes: the cyclical nature of environmental exploitation and the hope that small groups of idealists on the margins of mainstream culture might be capable of breaking this cycle. Although the interlaced settings seem doomed to patterns of destruction, Winterson's protagonists repeatedly, if futilely, express that new paradigms of thought are needed. Her main characters seem to be only ones who are sane in worlds gone mad. This positioning of the protagonists in relation to the fictional society reveals that a marginalized perspective — such as that of the cyborg or lesbian—on real-world social issues might help prevent the apocalypse to come.

Several book reviews and interviews with the author reinforce the importance of the novel's theme of cyclic destruction. Benedicte Page writes, "Amid themes of voyaging, shipwreck, self-destruction and transforming love, is an idea of new beginnings which turn out to be as old as the hills, and of an endlessly repeating world" (par. 7). Matthew Dennison agrees that the book is as much about destruction as it is about origins: "Winterson shows how, in struggling to record in words the world around us, we constantly reinvent the story of human 
creation" (par. 10). And Winterson herself claims, “'I don't want to sound like a doom-monger because I'm not one, I'm optimistic. I do feel we have every chance, but not unless we are realistic, both about our own negativity and our own possibility. The idea that we might be repeating the same mistakes is central to the book" (qtd. in "Science in Fiction..." par. 4). Each of these quotes reinforces the feminist post-apocalyptic notion that there is hope in destruction, but the cyclic nature of this novel casts doubt on the longevity of that brighter future. New worlds, whether the macrocosm of Planet Blue or the microcosm of Easter Island, are discovered only to be quickly ruined by human abuse.

The novel introduces the common science fiction trope of planetary discovery from its first line, "This new world weighs a yatto-gram" (Winterson 3). This line also frames the fresh planet's primary distinguishing feature in the parlance of consumer quantification, measuring it like a cosmic piece of fruit. After describing the bountiful nature of this new Planet Blue, the narrator, Billie, explains what has happened to her home planet: "The last hundred years have been hell. The doomsters and the environmentalists kept telling us we were as good as dead and, hey presto, not only do we find a new planet, but it is perfect for new life. This time, we'll be more careful. This time we will learn from our mistakes" (6). Naturally, there are traces of irony in her latter two sentences: she does not share in the optimism that her government has for the inviolate Planet Blue. In a heated conversation with her boss, Billie places the blame for her home-world Orbus's fate squarely on humankind, and she paints humankind as rapists and Orbus as the victim. "We didn't do anything, did we?" she asks sarcastically. "Just fucked it to death and kicked it when it wouldn't get up" (7). Later, as she reflects on her pessimism about her own society, Billie looks up at a projection of the pristine Planet Blue and has a fleeting vision:

She [Planet Blue] needs us like a bed needs bedbugs. "I'm sorry," I say, to the 
planet that can't hear me. And I wish she could sail through space, unfurling her white clouds to solar winds, and find a new orbit, empty of direction, where we cannot go, and where we will never find her, and where the sea, clean as a beginning, will wash away any trace of humankind. (22)

Such gendered personifications of setting are reminiscent of Annette Kolodny's "land-aswoman" metaphor in The Lay of the Land (1975). Kolodny explains how American writing that gendered the frontier as feminine helped motivate settlers to penetrate and despoil the virgin land (150).

Kolodny asserts that the "human, and decidedly feminine, impact of the landscape became a staple of the early promotional tracts, inviting prospective settlers to inhabit 'valleyes and plaines streaming with sweete Springs, like veynes in a naturall bodie,' and to explore 'hills and mountaines making a sensible proffer of hidden treasure, neuer yet searched"' (4). These descriptions whet the appetites of prospective settlers who were about to profit off the land "for commercial, religious, and political gains" (Kolodny 4). In Winterson's novel, the planet they are to settle upon—and ultimately destroy—is similarly depicted as verdant, pristine, and ripe for conquest in official reports (Winterson 30), and Billie perceives the planet as feminine (22). Other writing about post-apocalyptic space has been gendered as well. Dowling uses apt language, gendered maternally, to describe the construction of post-apocalyptic worlds: "We can then engage in restructuring our own experience and our own future in the present and out of the womb of the future" (86). The hope of rebuilding out of the ashes is, ironically, remarkably similar to the hopeful prospect of starting a new life in a virgin land; both are "wombs" out of which a new civilization might be born. This similarity reflects the cycle of discovery/violation/destruction that is apparent in the interlaced narratives of the novel. 
Like Kolodny, Winterson notes a gender difference in the way individuals perceive their relation to scientific progress and the natural world. When asked whether men and women see the benefits of technological innovations differently, Winterson responds,

There is a sense in which boys get mesmerised with the potential of invention in a mad, Dr Frankenstein way. Perhaps they believe in their own myths more than women do. Women are realistic probably because right across the world they're still the ones who tend the children, or look after the land. It's no wonder that we call the planet 'she.' (qtd. in "Science in Fiction..." par. 8)

One of the "masculine" myths that the novel challenges is the possibility of redemption through space age technology. In that same interview, Winterson refers to Stephen Hawking's ideas about man's future in space as "a boy's fantasy," and she believes that the utopian promises of the space program are misleading because we cannot just leave behind the world we've "trashed" (par. 3). Although Winterson may not be comfortable being labeled a feminist (Cornwell par. 11), these gendered approaches in her novel parallel the tropes of post-apocalyptic feminist fiction.

Winterson's novel also deploys gendered language and inter-gender conflict to challenge the patriarchal hegemonies which breed competitiveness, corporate greed, and environmental degradation. In "Planet Blue," when musing on the state of the sexes in her contemporary society, Billie thinks, “The future of women is uncertain. We don't breed in the womb any more, and if we aren't wanted for sex... [she trails off]. But there will always be men," whom she characterizes as "[t]hugs and gangsters, rapists and wife-beaters. ... They may smile like beachboys, but they are pure shark" (22). Feeling not only useless but surrounded by predatory and depraved men, it's no wonder that Billie goes along with a coercive deal to leave all this behind 
and attempt to settle on the new planet. While en route to Planet Blue, she gets into an argument with the macho ship captain Handsome. “'Women always bring it back to the personal,' said Handsome. 'It's why you can't be world leaders.' 'And men never do,' I said, 'which is why we end up with no world left to lead"” (57). Spike, the female android who becomes Billie's lover, declares, “"I am programmed not to over-masculinize data. That has been a serious mistake in the past"” (145). Even the male protagonist Billy in "Easter Island" uses gender-specific language to criticize his era's patriarchal goals: "Mankind, I hazard, wherever found, Civilized or Savage, cannot keep to any purpose for much length of time, except the purpose of destroying himself" (109). Billy is using the generic male pronoun to mimic the writing patterns of this past era, but the implications of this gendered terminology are apparent in the context of the novel.

In spite of the pessimism in this gendered narrative of destruction, Winterson acknowledges that love of the earth and hope for its redemption are the bottom line of her rhetoric: "I hope everyone will also understand that the book is my manifesto for what we could have, and that I can't bear the heartbreak of what we're doing to the beauty of this planet" (qtd. in "Science in Fiction..." par. 7). In contrast to the earlier post-apocalyptic novels, whose characters attempt to rebuild a better civilization through the traditional Adam-and-Eve saga of heterosexual regrowth, Winterson's novel finds hope in homosexual and even cyborg-human unions. She suggests that these marginalized viewpoints are better able to critique the mainstream culture and less likely to recreate the old "natural" paradigms. Winterson's two main characters, one a roguish lesbian and the other a feminine cyborg, articulate sensible ideas that could help guide humankind out of the cyclic patterns of destruction. Their statuses as lesbian and cyborg actually give them a strategic vantage point in the radical struggle against patriarchy: Bonnie Zimmerman declares that "lesbians have a unique and critical place at the margins of 
patriarchal society" (204) and thus can aid the feminist cause by more fully challenging heteronormative culture. And Donna Haraway's renowned essay “A Cyborg Manifesto" explains how theorizing about the cyborg offers "a slightly perverse shift of perspective [which] might better enable us to contest for meanings, as well as for other forms of power and pleasure in technologically mediated societies" (154). Haraway's conception of the cyborg as a heuristic approach to solving contemporary social problems embodies the belief that cyborgs, not fully human nor fully machine, offer a way out of the "maze of dualisms" which restrict Western thinking (181) —including male-female, animal-human, self-Other, and so forth, all elements of a tradition grounded in habits of perception that reinforce traditional hegemonies.

So when a loving relationship between the lesbian Billie and the cyborg Spike develops amidst the catastrophic decline of Planet Blue, their romance in the ashes symbolizes the hope for breaking the cycle of destruction. At the conclusion of "Planet Blue," Billie and Spike are alone on the planet as it descends into an ice age. Yet Billie takes solace in mental visions of future generations of men and women living and dying, fighting and dancing (92). As they descend into the frozen sleep of death, the narrator intones, "Close your eyes and sleep. Close your eyes and dream. This is one story. There will be another" (93). All they have left is each other, and even in the death throes of a planet destroyed by a government that has manipulated and discarded them millions of miles from the rest of human civilization, they tenderly accept this fate. At least they are together and beyond the dominion of Orbus's repressive capitalistic hegemony.

In fact, the tragic ending of each section includes dreams of a better beginning as envisioned by characters who do not identify with the values or goals of the culture around them. Billy and Spikkers in "Easter Island" also have a homosexual tryst which places them outside the 
pocket culture of the other Islanders, a perspective that reveals the folly of the Islanders' society and allows them to envision a different outcome for the people on the island. As their fate is sealed at the conclusion of their tale because of the Islanders' religiously motivated deforestation, they too die together, happily dreaming of another pristine place: “'In my dream,' he says, "the island is thick-forested like fur, and green and dark and alive. The waterfalls flow again and there is a lake as hidden as sleep" (115). Like the discovery of Planet Blue, there is seemingly endless promise in the primeval wilderness of which they dream. Similarly, as "Post-3 War" draws to a close, the narrator Billie again has a vision of a new world with new possibilities which she perceives as she is about to escape from her life with her future lover Spike: "I had a strange sensation, as if this were the edge of the world and one more step, just one more step..." (147). Finally, "Wreck City" concludes with the narrator waking up in an idyllic forest setting right after she departs from Spike and ostensibly is killed by gunfire (206). Each concluding circumstance is notable for being a beginning-in-an-end, a hopeful future conceived by a character who seems to be as much a victim of mankind's destructive impulses as the ruined worlds.

Winterson's novel suggests that, in spite of the cycle of catastrophe perpetuated by the current global civilization, there are dreamers in the margins who have better visions for the future. While trapped within the dominant ideology, it is difficult to perceive that there is any possible hope for a planet ravaged by war, industrialization, and consumption. "We have all been colonized by those origin myths, with their longing for fulfillment in apocalypse," Haraway explains; yet she hopes that, by "retelling origin stories, cyborg authors subvert the central myths of origin of Western culture" (175). Retelling our possible future will similarly subvert the myth of apocalypse, though we may have to look to the margins and outside the conventions of the 
very civilization that brought us to this point.

\section{New Beginnings in the Ruins}

Feminist post-apocalyptic fiction takes the potent formula of eschatological rhetoric one step further by making the end of the world a given and describing what happens next. Although these novels foreground the pessimistic notion of the cataclysmic "cleansing" of the old world, they each interrogate the designs of apocalypse in distinct ways. They are simultaneously warnings and urgent models for prevention. Carter's novel imagines a verdant paradise after the drastic decrease of the human species, though humanity's devolution ensures a return to barbarism and a loss of enlightenment. Isolation may be the only recourse for personal liberty in such a world because groups of humans tend to either cling to past institutions or revert to a pack mentality; one is either dominant or dominated, and in either state, chained to a brutal hierarchy. Lessing's novel suggests that the only way to overcome the downfall of civilization is to embrace new archetypes, enabling a utopian reconstruction of the established myth system from the ground up. This means not only escaping the old system but rewriting it, breaking conventions that restrict thinking and stifle inspiration. Butler's novel imagines that current trends in American culture will spell doom for the civilization unless they are redressed now. Strengthening communities, reevaluating religions, and promoting empathy will help to heal the wounds caused by race, gender, and class injustices. Winterson's novel rejects the inevitability of heterosexual paradigms, finding salvation for the future in a series of loving partnerships that transgress the boundaries of heterosexist and anthropocentric institutions. Since mainstream culture will not relinquish its power nor divert from its destructive course, it is up to marginalized groups to chart a sustainable future. Each author exploits anxieties about 
worldwide catastrophe for progressive rather than reactionary ends and simultaneously upsets the common teleology about the progress of civilization.

Interpreting these post-apocalyptic novels as feminist texts involves an imaginative exercise in contrasts. Once the reader has considered the outrageous but not impossible premise of worldwide catastrophe, then a profound social change, such as the shift from patriarchy to matriarchy in Carter's novel, seems less fantastic by comparison. After imagining the consequences of mutually assured destruction, nuclear disarmament seems far preferable. With science and medicine in shambles and the human organism exposed to dangerous chemicals and radiation, it is not much of a stretch to imagine the evolution of certain cognitive abilities, like the empathy of Butler's Lauren or the intuition of Lessing's narrator. Thus, former stereotypes about femininity could be transformed into future advancements for the human race as a whole. When the human population is so drastically reduced and civilization so regressed, even typically progressive social reforms of the present, such as gun control, are challenged; as Butler's nascent community realizes, arms are necessary for protecting one's community when the system fails to do so. For radical feminists, the system is already broken: it need not be reduced to ashes as proof. Apocalypse would only reverse progress for everyone and fulfill the desperate prophecies of warmongers and reactionaries.

The hope of a new beginning after apocalypse proves illusory in these novels. In each, the struggle to rebuild the world is an uphill battle because the collapse of civilization and the regression of humanity go hand in hand. If the problems of civilization are not "cured" by apocalypse - as all of these novels suggest - then what is gained by the annihilation of the present world? Waiting for the patriarchy to self-destruct is counterproductive because the collateral damage will be too severe. Apocalyptic rhetoric is notoriously urgent; it demands 
attention now. The ultimate hope, then, of the feminist post-apocalyptic mode is that the nightmare of apocalypse seems feasible enough to implant a moral obligation in the reader to avert catastrophe by rebuilding the pre-apocalyptic world. 


\title{
Chapter 3: Antiwar Dystopias and the Myths of Postmodern Wars
}

\author{
War is hell. \\ -William Tecumseh Sherman
}

When General Sherman uttered these words in 1879, he participated in what has become a modern trope: evoking the imagery of a horrific mythscape to discourage hawkish sentiments about war. Sherman's lesser-known precursor to this quote is crucial to the Union general's message: "It is only those who have neither fired a shot nor heard the shrieks and groans of the wounded who cry aloud for blood, more vengeance, more desolation" (qtd in Neuharth 21a). Whereas the realities of war might discourage the war-making process, narratives of the glories of war, the monstrousness of the enemy, and outrageous threats to one's way of life help to justify and sustain it. Some of western culture's earliest instances of written literature-Beowulf, the Iliad, the Old Testament story of Babylon — are inscriptions of marvelous narratives justifying war. Such popular myths serve the means and the ends of war-making. But polarizing hyperbole can also serve the movements against war when the appalling facts do not suffice. Stephen Duncombe asserts that, in $21^{\text {st }}$ century America, compelling narratives have more power to convince than mere facts, using the example of the popular myth of Iraq's connection to the 9/11 attacks to affirm that "[ $\mathrm{t}] \mathrm{ruth}$ and power belong to those who tell the better story" (7-8). To successfully oppose war, then, antiwar activists should tell more moving stories than the jingoistic myths that support war.

This chapter investigates futuristic antiwar mythscapes designed as speculative responses to two specific American conflicts: the Vietnam War and the "War on Terror." The conduct of postmodern warfare relies upon the dissemination of mythical narratives that attempt to convince the democratic public of war's necessity. The U.S.-Vietnam War was rife with such myths, which were propagated in order to initiate and sustain the conflict. In The Forever War (1972), 
Joe Haldeman challenges the pro-war myths of Vietnam by conveying the disillusionment and alienation of the soldier in the midst of perpetual war on a cosmic scale. The current wars in Iraq and Afghanistan, and collectively the "War on Terror," are also influenced by mythical associations and manipulative propaganda. Emerging during these wars, Bill Campbell's Sunshine Patriots (2004) imagines a futuristic Earth, united under global capitalism, that deploys media propaganda and overwhelming technological militarism on distant planets to further United Earth's imperialistic control, a process which annihilates or enslaves both the assaulted colonies and its own soldiers. These antiwar science fictions construct futuristic settings through allegory and hyperbole to critique the high-tech wars waged under the banners of freedom and capitalism, remaining conscious of the historical contexts of the real conflicts while alienating readers from their parochial (mis)conceptions of America's postmodern wars.

\section{Mythology and Postmodern War}

Roland Barthes defines myth as "a type of speech chosen by history" and "a system of communication" that serves to validate a culture's perception of itself (109-110). For Barthes, myths are not merely naïve stories from the past or primitive cultures: they continue to thrive in advanced civilizations as "depoliticized" discourses that ignore their own historical fabrications, make the cultural appear "natural," and simplify complex issues (142-143). This definition is useful for understanding the semantics of pro-war mythology. In the world imagined by that discourse, war is inevitable, like a natural disaster that must be weathered. To maintain moral higher ground, the history of one's own side is carefully fabricated to be unassailable, so that any injustices we may have committed are always justified, while theirs are always unforgivable. Ugly details are glossed over by a generalized narrative of good versus evil, hero versus villain- 
the type of narrative that fits in a world without gray areas, the world of fairy tales, in the sense of the war metaphors that George Lakoff describes (pars. 18-20).

The antiwar narratives of Haldeman and Campbell also build marvelous worlds, dystopian futures imagined as critical projections of an excessively militaristic, imperialistic present. But a crucial difference between these opposing rhetorical approaches is that the dominant pro-war mythologies pose as truth and attempt to disguise the myth, while the counternarratives in fiction pose as myth but attempt to elucidate some underlying truths; that is, the latter are self-reflexive regarding their mythical nature. Science fiction is nonmimetic by design, similar to the ethical spectacle that Duncombe defines. "[I]llusion is not the same as delusion," he claims, and a fantastic spectacle can be ethical if it openly acknowledges that it is a fantasy but moves the viewer nonetheless (147-151). Such a spectacle has the added benefit of engaging the viewer with Brecht's "alienation effect," in which the illusion is obvious and therefore never deludes the viewer into believing a false reality (Duncombe 144-145). The case is similar with these science fiction novels about war. Antiwar mythscapes extrapolate hyperbolically distant, violent, futuristic chronotopes (Bakhtin 84) from the contemporary realities of warfare, implicitly urging readers to reconsider the direction of the present culture in order to prevent these possible futures.

Some pro-war myths are blatant falsehoods that are accepted as truths, because to do otherwise would undermine fundamental beliefs about one's culture. Nicholas O'Shaughnessy claims that in the absence of "rational proof" to justify war, public sentiment relies on "emotional proof" in which "we feel intuitively that there is a causal connection, which is highly significant to the creation of some event and yet which cannot easily be pinned down; but we also believe this thing to be true because we have a deep emotional need for it to be true" (93). 
Because actual historical, cultural, and sociological reasons for waging war are complex and often involve dubious ethical motives, pro-war myths euphemize and obscure them. Even the naming of military operations serves to conceal the harshness of war under a comforting blanket of self-righteousness: “America's military campaigns - 'Just Cause', 'Provide Comfort', 'Enduring Freedom', 'Iraqi Freedom' - evince a moral supremacy and a selfless pursuit of justice" (Langille 321). The pro-war apparatus is cognizant of the need to tell a good story to sell the war, as is evident by their ambitious propaganda campaigns. In the Vietnam War, such campaigns took the form of trying to "win the hearts and minds" of the Vietnamese (Franklin 160), while during the Iraq War, U.S. propaganda was disseminated to Arab speakers via Radio Sawa, a "populist" station created by the United States (O'Shaughnessy 84). As pro-war myths multiply, any options besides war are silenced by specious associations, euphemisms, and carefully manipulated "facts."

Antiwar proponents must recognize the importance of narratives in countering these dominant myths if only because the facts alone are clearly not sufficient. In short, they need to disseminate counternarratives. A counternarrative exemplifies postmodernism's skepticism of "the 'official' and 'hegemonic' narratives," "those legitimating stories propagated for specific political purposes to manipulate public consciousness," by subverting the supposed consensus of the grand narrative (Peters and Lankshear 2). Postmodern novels are an ideal vehicle for conveying the diverse narratives that challenge the grand narrative by foregrounding "the binary opposing of the real to the fictive" and "suggesting that the non-fictional is as constructed and as narratively known as the fictive" (Hutcheon 76). By promoting the widespread study of postmodern works that address the issues of war in radical and imaginative ways, literary scholars can likewise demonstrate that mythical narratives are used to construct "History," so 
radically imaginative fictions might be used to deconstruct it.

I am not suggesting that facts have become meaningless in the face of pro-war rhetoric; indeed, citizens should objectively analyze any conflict waged in their nation's name by educating themselves on the histories and cultures involved. But I am proposing that the truth can be more convincing when framed in such a way that engages the emotions and grips the imagination, as Duncombe asserts: "It is not that reality doesn't exist — it is more that by itself it doesn't really matter. Reality is always refracted through the imagination, and it is through our imagination that we live our lives" (18). When numbers of soldiers killed do not deter ongoing combat; when the enemy's civilian casualties are ignored; when billions of dollars are spent to devastate weaker nations but challenges to the so-called defense budget go unheard; when all the hard facts about wars are elided and dismissed, then a more creative method may be necessary to challenge the pro-war myths. Because "it is extremely difficult to vanquish myth from the inside," as Barthes claims, "the best weapon against myth is perhaps to mythify it in its turn, and to produce an artificial myth" (135, emphasis in original). Antiwar proponents might overcome the dishonest myths of war by contesting them with opposing myths, compelling counternarratives that convey reasons to protest the war.

\section{The Pro-War Myths of the Vietnam War}

The myths about the United States' war with Vietnam are manifold and continue to obscure the reality of that conflict. H. Bruce Franklin's Vietnam and Other American Fantasies (2000) provides an excellent list of what he calls "the dominant fantasies" that are "accepted as true by most Americans" today: most notably, that South Vietnam was a originally a democracy that was invaded by the totalitarian Communist nation of North Vietnam (27-28). In fact, at the 
time of the Geneva Conventions of 1949, Vietnam was considered one nation (Franklin 29). It was divided only after the Democratic Republic of Vietnam's proposed elections were blocked by the United States, which, fearing a landslide election for Ho Chi Minh in 1956, installed a dictatorial regime in Saigon (Franklin 30, Perlstein 100). If, as the dominant myth contends, the United States was in Vietnam to protect the South Vietnam "democracy" from the North Vietnam "dictatorship," why would we oppose a president who would have been chosen by the people and support a dictator we knowingly appointed as leader of a country our side invented? The convoluted facts in this situation demonstrate that, despite its noble claims, the global capitalist regime only supports democracies that directly promote capitalism. This is where the myth becomes useful, because the truth is much too suspicious and complex for the conduct of a "just" war.

Another significant myth about our involvement in Vietnam was that America was forced to retaliate against the North Vietnamese Communists after the Gulf of Tonkin attack in 1964 (Franklin 28). Because of Americans' alleged unwillingness to commit to a full-scale war that did not directly threaten our national security, President Johnson required a pretext that would frame the war on Vietnam as defensive rather than offensive; thus, an alleged attack on U.S. naval cruisers positioned in the Gulf of Tonkin in 1964 was propagated — despite the fact that "there was little if any evidence that the attacks actually took place" (Stacewicz 85). Skepticism about the veracity of those attacks is not new. Even in 1967, Joseph C. Goulden's book Truth is the First Casualty "revealed that the Gulf of Tonkin pretext LBJ used to secure congressional permission to escalate had been a fraud" (Perlstein 418). But by then, of course, the United States was deeply embroiled in Vietnam, and the myth had done its duty. President Nixon was also adept at manipulating his war rhetoric to favor his political machinations. Nixon ran in 1968 
as the candidate who would make peace with the enemy, yet he "sabotaged the negotiations" in the peace talks before the election, promising that "he would give them a better deal" once he was President (Perlstein 350). His populist claim of being the candidate for peace was repeatedly belied by his administration's perpetuation of the war. During his presidency, Nixon withdrew troops from Vietnam while secretly escalating the bombing in Cambodia, even deceiving his own Cabinet about the campaign before it began (Perlstein 362). With all the secrets and lies about Vietnam disseminated by the administrations of these opposing-party Presidents, myths about the conflict were rampant.

During and since the war, Hollywood movies have also fueled the myths about Vietnam, often supplanting the historical truths with brazen spectacle. J. Hoberman asserts that "the Vietnam War was spectacular - in the literal sense....Vietnam was also a movie. Our movie. Our greatest hit. Our biggest bomb" (176). The conflation of cinema and war is especially pertinent considering the war was piped into American homes via the evening news. Hollywood films also helped to influence and shape public perception of the war: Franklin writes how compelling fantasies from films such as The Deer Hunter (1978) and Rambo: First Blood Part II (1985) helped to rewrite the history of that war in the popular imagination $(17,192-5)$. The John Wayne film The Green Berets (1968) depicts Vietnamese Communists as torturers of children and has the audacity to suggest that the so-called liberal media of the U.S. censored negative stories about the enemy when, in fact, "enemy atrocities were the second-most common news report out of Vietnam" (Perlstein 278). John Wayne seemed to be a mythical icon of American masculinity whom young soldiers sought to emulate in this era. Loren Baritz claims, "'It is astonishing how often American GIs in Vietnam approvingly referred to John Wayne, not as a movie star, but as a model and a standard"' (qtd. in Hoberman 177). Maureen Ryan recognizes Wayne's influence on 
the war as well, and she defines Vietnam veteran John Kerry's phrase “"the John Wayne syndrome"” (qtd in 34) as "the recurrent metaphor for the fatally romantic macho-heroic myth that sent young American males to Vietnam" (21). Veteran Danny Friedman describes "the John Wayne mystique" as a myth that influenced his decision to fight: "You've got to do the right thing. Yours is not to question why; yours is to kick ass on the commies and win the pretty girl. I wasn't unique. This was what most people thought" (qtd. in Stacewicz 46). When a Hollywood actor's bombastic image influences soldiers' perception of themselves and America, it is clear that the pro-war myths have a strong grip on the popular imagination.

With all this myth-making by politicians and popular culture, perhaps more reliable inroads to the realities of the Vietnam War may be found in veterans' narratives. But even these are rife with myths, though in many cases they are acknowledged as such through the veterans' hindsight. Richard Stacewicz's Winter Soldiers (2008) contains interviews with a number of Vietnam Veterans Against the War (VVAW). Many veterans claim to have known very little about Vietnam or world politics when they entered the war. In retrospect, these veterans acknowledge that patriotic and anticommunist propaganda provided a host of myths which encouraged them to fight. Barry Romo recalls, "I thought I was going to Vietnam to save my Catholic brothers and kill communists, who were the new Nazis in the world" (qtd. in Stacewicz 26). The ease with which the animosity against the reactionary Nazis was transferred to the Viet Cong exemplifies how America's enemies are depicted in rather broad strokes. Similarly, John Kniffin declares, "I was brought up to believe that the communists were the Antichrist; you know - they were going to destroy western civilization" (qtd. in Stacewicz 42). These statements insinuate the dubious collusion between Christian-based religious fervor and violent capitalist imperialism, which remains a tenacious contradiction in conservative politics today. 
Veteran John Barry condemns the duplicity with which the war was conducted, describing the disconnect between the untruths told in Washington and the realities of the battlefield. He seems to have been especially frustrated with the lack of resources available for making sense of that reality, observing, "I had no other context in which to put any of this stuff. There wasn't a book around you could get a hold of and read any of this stuff' (qtd. in Stacewicz 91). However, during the final years of the war, Haldeman, another Vietnam veteran, was serially publishing an antiwar science fiction novel in Analog Science Fiction from 1972-1974 (Disch 184). As a popular fiction genre, science fiction reaches the public, and as Stacewicz confirms, many returning veterans sought to change the public's attitude towards the war (189). However, their authoritative knowledge of the truth about Vietnam made them special targets of the national security apparatus (Stacewicz 316), which may have created the need for more subtle approaches to subverting the war effort. Haldeman's novel was not overtly about Vietnam, but that war seethed just beneath the surface of this science fiction narrative.

\section{Haldeman's The Forever War}

Science fiction and war are not uncommon bedfellows. But while writers like Robert Heinlein tend to glorify warfare with depictions of futuristic technologies that annihilate threats to humanity (e.g. Heinlein's Starship Troopers [1959]), Haldeman uses science fiction to critique militarism through hyperbole and estrangement. From its title on, The Forever War confronts the reader with the core anxieties of postmodern combat in the Vietnam War era: a distant war without end, with coerced enlistment, inscrutable enemies, dehumanizing technologies, and maddening politics. Franklin writes, "Haldeman explodes the pet practices and illusions of U.S. militarism by taking them to absurdly fantastic dimensions" (165), and indeed, hyperbole is a 
dominant method through which the author frames his criticisms of the war. Although there are many realistic fictions and memoirs about the war, such as Tim O'Brien's The Things They Carried (1990) and Michael Herr's Dispatches (1977), The Forever War is notable for being a science fiction war novel by a Vietnam veteran. Perhaps Haldeman chooses the science fictional approach because his experiences in Vietnam led him to speculate on how warfare might evolve if current methods of American militarism were extrapolated into the distant future. In the preface, he confesses that the novel is "about Vietnam, because that's the war the author was in. But it's mainly about war, about soldiers, and about the reasons we think we need them" (xv). Any veteran who survives with their sanity and identity intact enough to write a book participates in a process of "self-preservation" as he or she struggles to make sense of the war and normal life again (Harari 71), and the distancing that science fiction effects can help the author establish an extra layer of objectivity between himself and the war he actually experienced.

In The Forever War, Haldeman overturns the "John Wayne syndrome's" fantasy of war as a personally fulfilling, glorious, and honorable pursuit by depicting it as profoundly alienating and practically meaningless. Ironically, this war novel actually foregrounds very little direct combat during its 1,143-year saga. William Mandella, the protagonist-narrator, is a soldier who endures the entire war (interstellar travel compresses time, so that a millennium in Earth-time can equate to only a few years for the traveler). Mandella begins as a private and survives to be a decorated major by the war's end. Earth's soldiers are sent across space to numerous planets to fight Taurans, a species of humanoids that humans had earlier attacked on their first encounter. The war is sustained all these years simply because of that initial knee-jerk hostility and the species' inability to communicate with each other. But these facts are not apparent to Mandella 
until after the war is over. Over the course of his military career, when the world in which he grew up becomes extinct and his comrades are killed or displaced across time, Mandella realizes that his fellow soldier, Marygay Potter, represents all that is meaningful and worthwhile to him. The dystopian future setting of the novel dramatizes the extreme disillusionment and alienation of soldiers in Vietnam, and the implied temporal projection from the author's present amplifies the narrator's reflections on war, particularly his critiques of dehumanizing military technologies and the complex struggle between animosity and compassion for the alien enemy.

Haldeman's futuristic setting provides a fictional space in which to speculate on imaginative technologies, most significantly those involving space travel and advanced weaponry. The advanced technology of the futuristic warfare alternately excites and horrifies the characters, and some technologies, particularly space travel, prove to be profoundly alienating to the soldiers who are caught in its mechanisms. Franklin describes how "Haldeman delights in twisting the futuristic hardware and adventure formulas of old-fashioned militaristic science fiction into their opposite" (165), meaning that often the benefits of advanced technology are outweighed by their downfalls. For instance, spaceships make interstellar travel possible, but they also alienate the soldiers from their home lives (through temporal expansion) and trap them in dangerous situations: while in transit to a war zone, Mandella rouses from interstellar hibernation to discover that Marygay has been hideously wounded by a defect in the ship's mechanisms, resulting in a confusing scramble to save her life (Haldeman 95-102). Real stories from Vietnam reflect this distrust of military equipment, particularly modes of transport. John Barry recalls the unreliable equipment soldiers had to use, describing outmoded helicopters "that literally came apart in midair, crashed, and killed people" and airplanes "held together with spit, baling wire, and chewing gum" (qtd. in Stacewicz 88). Both in the novel and the war, advanced 
technologies make these distant wars possible, but they also create appalling hazards for the soldiers who rely on them.

The earthlings' advanced weaponry also spurs criticisms from the narrator. He describes a huge laser that fires whenever the trigger is not pressed: in default mode, "it would automatically aim for any moving aerial object and fire at will...The aiming computer could choose up to twelve targets appearing simultaneously (firing at the largest ones first). And it would get all twelve in the space of half a second" (Haldeman 41). The implicit criticism here is that the weapon does not need a human's judgment to initiate a murderous frenzy, only to stop it. Efficient and unquestioning, this weapon is the ideal killer-especially in those situations, like the ones in Vietnam, where soldiers were ordered to "shoot anything that moved" (qtd. in Perlstein 441). As the war drags on over the centuries, awareness of the perpetual arms race between the two civilizations dampens the narrator's excitement about the "new toys" his soldiers are bringing to the battlefield: "No matter how physically impressive the weapons were, their effectiveness would depend on what the Taurans could throw back. A Greek phalanx must have looked pretty impressive, but it wouldn't do too well against a single man with a flamethrower" (Haldeman 230). By evoking the flamethrower, a notorious Vietnam-era weapon, in contrast with ancient warfare, the novel trenchantly exposes the temporal relativity of military technology.

The novel also espouses a profound skepticism with military intelligence and its effects on the conduct of war. Bureaucracy obscures information behind layers of military secrecy or just poor intelligence. After hearing some notes about their planetary destination, one soldier asks, ““[A]nybody know what we're going to do when we get there?” to which the officer shrugs and replies, "We just don't have enough data yet to project a course of action for you. It 
may be a long and bloody battle; it may be just a case of walking in to pick up the pieces" (Haldeman 45). In fact, the soldiers' first encounter with the Taurans results in a massacre and an easy victory for the humans. Their surprise assault on a Tauran settlement recalls the images of, and perhaps the mindset behind, similar village massacres in Vietnam. Sergeant Cortez points to a map and explains to his troops, “'First thing we'll hit is this row of huts, probably billets or bunkers, but who the hell knows....Our initial objective is to destroy these buildings."' Potter asks, “'Why can't we jump over them?" to which the sergeant replies, “'Yeah, we could do that, and wind up completely surrounded, cut to ribbons. We take the buildings"” (Haldeman 65). Such a totalizing, all-or-nothing approach must have also been commonplace in Vietnam, in which enemy soldiers and Vietnamese civilians may have seemed indistinguishable at times. Perlstein describes "dehumanizing routines of the Vietnam conflict" including "free-fire zones" and "the rule that if a hut had an air-raid bunker it could be burned to the ground, its occupants listed as enemy kills" (481). The unknowable otherness of the alien enemy (similar to the stereotype of the "inscrutable Oriental") coupled with an unconditional sense of self-preservation sometimes rendered moot such technicalities as the distinction between innocent civilians or enemy soldiers.

The narrator's thoughtful reflections on his encounters with the enemy reveal a certain compassion and sympathy which is contrasted with the duplicitous messages about the enemy from military command. Right before the human soldiers finally attack a Tauran settlement, combat-hungry Cortez feeds them propaganda about their enemies. To those who wish to be merciful with them, he declares, “'Mercy is a luxury, a weakness we can't afford to indulge in at this stage of the war"' (68). To drive home this sentiment, Cortez gives his soldiers a specious reason to ratchet up their hate for the enemy: 
'They are responsible for the lives of your comrades who died in training, and for Ho, and for all the others who are surely to die today. I can't understand anybody who wants to spare them. But that doesn't make any difference. You have your orders and, what the hell, you might as well know, all of you have a post-hypnotic suggestion that I will trigger by a phrase, just before the battle. It will make your job easier.' (Haldeman 68, emphasis in original)

Later, Cortez shouts a bit of verse during the assault on the settlement, and sure enough, Mandella's mind is bombarded with "pseudomemories" of the Taurans attacking human ships, eating human babies, raping human women, "a hundred grisly details as sharply remembered as the events of a minute ago, ridiculously overdone and logically absurd" (70-71). Although Mandella consciously repudiates the impossible images, he realizes that "deep down in that sleeping animal where we keep our real motives and morals, something was thirsting for alien blood, secure in the conviction that the noblest thing a man could do would be to die killing one of those horrible monsters" (71). This rhetoric of hate is similar to the methods by which the American soldiers were taught to hate the Vietnamese and revile them as "subhuman" (Perlstein 557). Mandella slaughters the Taurans with gleeful abandon despite the fact that he knows the lies are untrue. The posthypnotic images just make his duty easier.

But they do not prevent the onset of remorse. After his battle fury abates, Mandella concedes that what they'd done was "murder, unadorned butchery" (76). He considers what it might have been like if the humans had tried to communicate with this intelligent species, the first humans have ever encountered besides themselves, then poses a fundamental critique of real-life wars with chilling implications for future wars: "Back in the twentieth century, they had established to everybody's satisfaction that 'I was just following orders' was an inadequate 
excuse for inhuman conduct... but what can you do when the orders come from deep down in that puppet master of the unconscious?" (77, ellipsis in original). Mandella's regrets quickly lead him to the conclusion, "I was disgusted with the human race, disgusted with the army and horrified at the prospect of living with myself for another century or so" (77). This sequence reveals the double bind (Bateson 206-207) in which the combat soldiers are placed. On the one hand, they cannot allow such evil creatures to live, as the army propaganda has drilled into their subconscious. Even the possibility of enemy hostilities ensures that their own sense of selfpreservation is a powerful motivator, and refusing an order can be fatal on the battlefield. But knowing the propaganda for what it is, the narrator cannot help but feel powerful remorse when the killing is done.

That posthypnotic suggestions could have more tenacious consequences is not lost on the soldiers, one of whom tells Mandella, "If they could condition us to kill on cue, they can condition us to do almost anything. Re-enlist" (Haldeman 109). Through this estranging and hyperbolic way, Haldeman grapples with the very real post-traumatic stress disorders suffered by many of his fellow veterans. Furthermore, the characters' suspicions about their indoctrination reveal a deep schism between the front-line soldier and their commanders. In the war in Vietnam, an extreme manifestation of this alienation resulted in the practice of "fragging"killing one's officers during combat (Franklin 64). In addition to alienation between ranks, the war also caused many to feel alienated from the lives they left behind. Army medic Jack McCloskey recalls how "the world"-meaning civilian life in the United States-seemed to have changed irrevocably upon his return from Vietnam: "When we came back to the world, it wasn't the world we left: your girlfriend's changed, you've changed—-so you go through this psychological 'Hey, what the fuck is this here in the world? This is the world I fought for?"' 
(qtd. in Stacewicz 99). Haldeman's mythscape symbolizes this alienation through the temporal expansion of space travel. When the soldiers finally do get a chance to return home, decades and eventually centuries have passed since they were there. The narrator complains that he feels little loyalty to "the perverse grotesquerie we were supposedly fighting to preserve" (177). The war's absurd duration is the greatest hyperbole in the novel, and it unifies some of its core themes, alienation, distrust of technology, and loss of historical context, all of which notoriously characterize the actual war.

Haldeman's novel engages with the present state of American imperialism through the rhetoric of a hyperbolic future, pessimistically assuming that the United States will never learn the lessons that the Vietnam War should have taught us about global affairs. The Forever War questions whether the patriotic impulse is strong enough to compel citizens to die for their country in a war if the country is no longer recognizable as a consequence of that war. This must have been a reasonable question for veterans like Haldeman, who returned home to find that American culture was changing significantly—partly as a result of the very war they had been fighting. Ideally, this novelistic mythscape also helped to cultivate skepticism about the myths and motives behind the real war. The novel's science-fictional nature does not forfeit its potential for conveying kernels of truth: Tim O'Brien explains how a "true war story" does not depend upon absolute truths so much as how well it conveys the "surreal seemingness" of war to the soldiers who lived through it (68). "You can tell a true war story by the way it never seems to end," O’Brien declares, “[n]ot then, not ever” (72). Likewise, The Forever War stretches into an indefinite future, and its ending is bathetic, not glorious. Perhaps this novel reflects the feelings of many troops returning from Vietnam, who were denied the glories promised by John Wayne, and who were unable to leave the war even after leaving Southeast Asia. 


\section{Mythology and the War on Terror}

There is a certain safe intellectual distance in pondering how myths affected past wars. But it is much more urgent and discomfiting to consider the myths that drive our current wars. Terrorist attacks by Islamic fundamentalists and the subsequent "War on Terror" have ensured that the first decade of the $21^{\text {st }}$ century will be regarded as an era of prolific bloodshed. As prowar myths continue to go unchallenged, and war atrocities on all sides guarantee another generation of bad blood, this multi-front war seems far from over. Yet the amount of antiwar literature in response to our current wars pales in comparison to the expressions of protest disseminated during the Vietnam era, while the proponents of the War on Terror have been hard at work forging myths to justify it.

After the 9/11 attacks, the Bush administration propagated "a new myth of the American nation as victim and saviour" (Gare 280). Using oversimplified, abstract language, President Bush declared that "the United States had been struck because of its love of freedom. 'America was targeted for attack,' he maintained, 'because we're the brightest beacon for freedom and opportunity in the world"' (qtd. in Corn 14). To the wounded nation, such a myth is compelling, yet it completely elides the United States' decades of self-serving involvement in world politics, during which we abused our superior economic and military power to the point that we were anything but freedom-loving bystanders. The myth enables profound amnesia about the U.S.'s imperialistic manipulations of Afghanistan, Iraq, Vietnam, Cambodia, Chile, Israel/Palestine, Korea, and other sovereign nations throughout the latter half of the $20^{\text {th }}$ century. This version “covered up complexities and denied Americans information crucial for developing a full understanding of the attacks" (Corn 14), and thus sought to efficiently dispel the public's 
confusions and redirect their energies towards making war.

David Corn styles Bush’s pro-war mythology as “a comicbook interpretation” (14), and this approach is useful for analyzing how much of the current war mythology works. It effectively shoehorns the complex historical and cultural contexts of these conflicts into a simplistic formula of good-vs.-evil recognizable from many popular fictions - movies, television dramas, comic books, etc — and then exploits these genres' tropes through methods easily disseminated by media. Langille writes that Bush, "facilitated by a compliant and credulous mass media," sold the American people a simplified "ideological package" that cast themselves as morally superior crusaders and thereby justified any antagonistic policies against the Muslim and Arab world (322). Mass media outlets in America help to propagate these myths because scare tactics are more exciting (read: produce better ratings) than historical analyses and reasoned debates over why such anti-American animosity exists. Duncombe laments, “[T]he Pentagon understood that people often prefer a simple, dramatic story to the complicated truth. Weaned on endless advertisements, sitcoms, and Hollywood movies, we've learned to find comfort in compelling narratives and change the channel when confronted with messy facts" (7). In addition, post-9/11 nationalism and Bush's polarizing rule, "You're either with us, or you're with the terrorists," have branded most attempts to understand the motives behind the attacks the equivalent of appeasing the terrorists. Widespread faith in these myths seems to prevent any possibility but war.

The necessary opposite to the populist myth of America's heroic innocence is the myth of a purely evil villain whom the public can revile. Such a villain deserves punishment so badly that any violence can be deemed appropriate to bring him to justice. The sensationalist media “upholds a simplistic 'madman' thesis of global terrorism, obsessed with small pockets of 
evildoers-larger-than-life villains like Osama bin Laden, Saddam Hussein, and Slobodan Milosevic — prepared to destroy Western values" (Boggs and Pollard 336). These men are reduced to symbols, wellsprings for all anti-American sentiment and human wickedness in general, engendering the notion that if only these villains can be slain, Evil will be defeated and Good triumph. Joseph Campbell writes, "[I]t is a basic idea of practically every war mythology that the enemy is a monster and that in killing him one is protecting the only truly valuable order of human life on earth, which is that, of course, of one's own people" (171). Such villains become the source of evil rather than products of their historic and cultural environment, thereby absolving the United States of any complicity in their roles - despite the fact that the CIA helped to train bin Laden (Gare 263) and the U.S. supported Hussein's rise to power during the 1980s (Gare 264).

The Bush administration depicted bin Laden as "a would-be conqueror of the world, a man motivated solely by irrational evil, who killed for the purpose of destroying freedom" (Corn 14). Such a characterization of bin Laden is tailor-made to suit the pro-war myth. The little white lie that bin Laden seeks to destroy freedom, rather than American hegemony in global politics, feigns ignorance of widespread disgust with American imperialist policies, especially in the Middle East. Of course, many Americans equate America with freedom and freedom with capitalism, so to them, the rhetorical assertion that bin Laden wants to destroy freedom must seem valid. But if America is perceived as simply promoting freedom for all and is never responsible for unjust global policies, then even realistic grievances against America can be dismissed. In this mindset, bin Laden seems to emerge out of nowhere, determined to destroy us just because we support liberal humanist values. Similarly, as the representative villain of Iraq, "Saddam made the perfect enemy: he was a stage villain ordained by central casting complete 
with heavy moustache and feodora" (O'Shaughnessy 91). According to the pro-war myths, Saddam Hussein and bin Laden are less real people than symbols of evil with no history who have created and sustained anti-Americanism through deception and coercion.

Although bin Laden and Hussein could be insane and both support tyrannical ideologies, the villain myth creates a simple "fairy tale" of a just war, as George Lakoff defines it (par. 1920). If there is a villain, there must be a hero, who "is moral and courageous, while the villain is amoral and vicious. The hero is rational, but though the villain may be cunning and calculating, he cannot be reasoned with. Heroes thus cannot negotiate with villains; they must defeat them" (Lakoff par. 20). Thus, war becomes the only option, and the hero must stop at nothing to destroy the villain. The complexity of war is reduced to a simple, easily recognizable narrative of hero vs. villain, and in the fairy tale, the world is made whole and good once the villain is defeated. Yet already the villain myth has been proven false, because even though Hussein has been cast down and slain, the Iraq War rages on. Worse, the myth exacerbates and prolongs animosity between the two cultures: such a characterization of the enemy's leader is a short step away from the vilification of all Muslims and Middle Eastern peoples. Boggs and Pollard explain how Hollywood cinema, replete with "seemingly non-political content" that disguises its ideological manipulation, fuels the myths of the War on Terror by making racist caricatures of Islamic fundamentalists and superhuman icons of pro-American film heroes (347). When Middle Eastern or Muslim appearance becomes interchangeable with "terrorism" in popular discourse, then it is easy to see how the villain myth comes to represent an entire people.

The WMD debacle "justifying" the Iraq War proves that ultimately myths can have a much greater role than facts in justifying wars: if a nation is truly out for blood, then facts can be invented or ignored while the myth endures. The power of myth ensures that it is "easier for 
George Bush (and most United States citizens) to call to mind weapons of mass destruction and all the terrible things Saddam Hussein might do with them than to imagine ways in which to resolve differences with Iraq peacefully" (Schroeder 1697). Definitive intelligence about the absence of WMDs seemed less compelling than questionable intelligence about their presence. Pro-war myths also forged conspiratorial links between Iraq and the terrorist attacks on 9/11. Duncombe notes how making false connections through association is an insidious but effective method of creating these myths: "By constantly referring to Iraq in the same sentence as terrorism, and Saddam Hussein in the same breath as al-Qaeda, the [Bush] administration forged an association that continues today" (89). Such specious reasoning lends credence to O'Shaughnessy's notion of “emotional proof": while there may not be any rational proof that Hussein had direct ties with bin Laden or that the Iraqi dictator possessed weapons of mass destruction, the majority of our leaders and citizenry were convinced intuitively that these must claims be true (93). If emotional proof is all that the United States needs to go to war, then we have set a dangerous precedent making it appropriate for nations to ignore the UN and declare wars because of gut feelings, hunches, and the need for misdirected vengeance. With such popular myths justifying war, counternarratives against the war face an uphill struggle.

\section{Campbell's Sunshine Patriots}

Although Bill Campbell wrote Sunshine Patriots in 1998, it was not published until 2004 when the author toured to promote his antiwar book amidst a decidedly pro-war climate (Campbell, Bill, “The Cyborgs...”, par. 1). Campbell's mythscape shares many similarities with Haldeman's. Both are set on distant planets, where the soldier-protagonists are at war with the inhabitants; both reveal deep schisms between the "grunts" fighting and the politicians who send 
them to fight; both depict futuristic dystopias that implicitly critique policies of their time. However, Sunshine Patriots foregrounds several tropes of futuristic militarism that dramatize Campbell's criticisms of global capitalism. Because its core conflict is the war between the United Earth military and a sympathetic cadre of rebels on a distant planet, the novel questions America's self-appointed role as world police and defenders of democracy. A second key trope is the cyborg as symbol of both technoscientific empowerment and dehumanization, suggesting that the might of high-tech militarism necessitates enslavement to those very technologies. Thirdly, the afrofuturist themes in the novel suggest that spiritual traditions can be sources of hope and solidarity when violent imperialist forces threaten to overwhelm diverse nations.

Campbell's novel pits the United Earth against The Be. The former represents a totalizing ideology based on militant capitalism disguised as democracy, while the latter represents a localized, intimate ideology based on community and non-materialistic cultural traditions. Soldiers from United Earth, led by the celebrity war hero Aaron Barber (nicknamed "The Berber"), conduct a technologically superior campaign against a small group of human rebels on the planet Elysia. The "Libertary" forces, the 2200's hateful term for all rebels against the empire (reflecting contemporary conservatives' vitriol against all things "liberal"), are demonized by Earth's empire for seeking to defend their right to self-determination. Initially the campaign seems to be another easy victory for United Earth; their bombing of the Demeter colony eradicates most of its population, and their obvious military superiority promises similar annihilation for the planet's other colonies. But the rebels' pseudo-religious faith in "The Be," a Gaia-like entity of Elysia, as well as their alliance with an alien species that permeates the planet's flora and fauna, aids them in driving off the United Earth military and opens The Berber's eyes to the injustice of their campaign. The omniscient narrator of the novel reveals the 
truth of the war, and unlike the population subjected to the pro-war propaganda, the reader learns to distrust the lies, sympathize with the rebels, and take pity upon the hapless soldiers who are enslaved to their own army.

By transplanting the mission of global imperialism to a far-flung planet, Sunshine Patriots is an extreme vision of the postmodern era's capitalist domination under both neoliberal and neoconservative auspices. David Harvey explains how capitalistic interests around the world conspire to ensure a global regime under the banner of neoliberal ideals: "The fundamental mission of the neo-liberal state is to create a 'good business climate' and therefore to optimize conditions for capital accumulation no matter what the consequences for employment or social well-being" (25). Freedom — the ironic nickname for the United Earth's armed forces—is interpreted by neoliberalism as "freedom of the market and of trade," not political sovereignty (11). Harvey contends that "the neo-liberal state is hostile to (and in some instances overtly repressive of) all forms of social solidarity" (25). The attack of the United Earth on the planet Elysia is a violent campaign to eradicate any dissent, no matter how distant, from the (inter-) global consensus.

While The Freedom is utterly annihilating the colony of Demeter, a propagandistic commercial featuring a simulacrum of the ideal soldier, The Berber, plays at home. Barber intones,

We soldiers, like our President, understand that freedom comes with a heavy price. It is something that is paid for in bravery, and in blood. While many weak, so-called 'leaders' whine and moan about due process, habeas corpus, and a whole bunch of other words I can't pronounce, President Gertrude SchmidtYakomoto has done what it takes to protect United Earth's peace, tranquility, and 
economic prosperity. She and her Freedom Party understand the sacrifices we all must make in order to protect those precious freedoms. (20)

This speech summarizes the contradictions of the actual global effort to impose "freedom" on the world. Legislative protections guaranteeing real freedoms are dismissed, while military actions claiming to impose "freedom" on rebellious nations are defended as necessary to domestic security. Such claims mirror real-world propaganda which contends that so-called freedom can be forced upon other sovereign nations through overwhelming military force.

Many of the Elsyian rebels are former United Earth veterans who ultimately rejected their obligations to the vampiric military, just as Barber eventually does. The rebels' desertion from the United Earth army is akin to slaves fleeing from their bondage. But these soldiers become enslaved to the costly technologies that keep them alive after they are wounded in combat: one veteran-rebel, Rattan, is a man whose "body, mostly scar tissue, was now a living testament to the horrors of battle. With an artificial DuraLung, DuraKidney, and polymer tubing for arteries and veins, only the long raven hair that cascaded down his back remained [his own]" (7). UE soldiers, many of whom are conscripted as children, are subjected to intense physical and mental conditioning designed to override their individual agency. A young, naïve recruit considers how "[e]ven his sleep had been invaded by training, the neural tapes plugged into his temples, drilling his dreams into the perfect soldier" (22). Another veteran-rebel, Hardy, reflects caustically on her experiences with the UE: "She'd been too young not to swallow 'peace, tranquility, and economic prosperity' hook, line, and sinker. She'd even lost her arm, ear, and intestines for them. How did they repay her? They didn't even bother. In fact, she had owed them" (140). While in combat, soldiers are drugged to enhance their killing instinct; more advanced soldiers have a Brain2, a computerized mental apparatus that is programmed to make them efficient 
fighters; after combat, they are "rewarded" with any drugs they want, though most soldiers become hopelessly in debt to the army for these; the rape of new recruits or "hymies" is standard procedure between units; wounded soldiers are rebuilt with cybernetics and sent back to the front. What begins as allegedly voluntary conscription always ends as enslavement (or death), and the longer the soldiers are in the UE military, the heavier their bondage becomes.

Enslavement to the army is all but assured as the human soldier becomes rebuilt by expensive robotic parts, which the soldier must pay for him- or herself. The cybernetic elements in the novel have a contradictory role: on one hand, they empower the soldiers, making them into better warriors; but on the other hand, they dehumanize the soldiers, subjecting them to the absolute dominion of the military. Wounded soldiers once had the privilege of leaving the combat zone as decorated veterans, but cyborg soldiers find that their wounds are excuses to rebuild them into tools of the state. Through his years of service, Barber has become the ultimate tool of the military: he has lost most of his original body, even his mouth, yet his heroic simulacrum continues to spread government propaganda to the United Earth public when the real Barber can no longer even express himself (except via telepathy with his closest friends). Donna Haraway defines the cybernetic organism, or cyborg, as "a fusion of the organic and the technical forged in particular, historical, cultural practices" that was initially imagined as necessary for space travel (Modest_Witness 51). She considers cyborgs to be the products of technoscientific globalism which springs from the $20^{\text {th }}$ century military industrial complex (Modest_Witness 13). Campbell's cyborgs are the products of a brand of militarism that owns its soldiers, body and mind. The Brain2 is the extreme example of this. Embedded in the base of the organic brain, a Brain 2 takes over the instinctive responses of the organism by programming the soldiers to fight fearlessly and with efficient precision. And if advanced cyborg soldiers ever 
defy the army, their Brain2s explode, killing them instantly. Like Haldeman's posthypnotic suggestions, the Brain2s steal the free will of the Freedom's soldiers.

Yet the symbolic function of the cyborg complicates the notion of a purely programmable soldier; after all, by definition cyborgs are both human and machine. Haraway explains how "[h]igh-tech culture," represented by the cyborg, challenges the major dualisms that are fundamental to Western thought and have been agents of domination, particularly for women and people of color (“Cyborg,” 177). So as the cyborg soldiers' organic bodies are replaced by machines, they begin to physically transcend the corporal limitations of the human body and, ideally, the cultural signifiers affixed to that body. With metallic phalluses implanted on strong female warriors (Sunshine 99), the cyborg soldiers revise traditional gender roles by possessing the corporal signifier of maleness. Race can also be transcended by the cyborg, as the bodily signifiers of race, mapped through the genes onto the human form, become replaced by uniform metal.

But despite the "racelessness" of their metal parts, the soldiers have not risen above racism: in fact, they tend to cling to their race as something distinctly human and personal. Throughout the UE army, the soldiers congregate with like races into groups, labeled with racist tags like Nigs and Chingoes, which they appropriate as terms of solidarity. The novel's complex negotiation of race issues can be illuminated by the concept of Afrofuturism. Lisa Yaszek defines Afrofuturism as an "aesthetic mode that encompasses a diverse range of artists working in different genres and media who are united by their shared interest in projecting black futures derived from Afrodiasporic experiences" (42). She proposes that Afrofuturist authors "draw upon Afrodiasporic history and culture to tell complex and sometimes contradictory stories about how and why race relations might continue to matter in the future" (55), suggesting that the 
grand narratives of dystopian futures prophesied by $21^{\text {st }}$ century doomsayers can be countered by narratives drawn from Afrofuturism. Likewise, in the novel, real ancestral magic, interconnecting The Be of Elysia with Corporal Mbili's African ancestors, subverts the technological juggernaut of the UE military.

Mbili, Barber's right hand man, undergoes a crisis of the spirit on Elysia that dramatizes the Afrofuturist trope of the African past helping to guide the collective future. The campaign on Elysia brings him into contact with The $\mathrm{Be}$, and its magic reminds him that he has lost touch with his ancestral faith. Although Mbili pretends to engage in shamanistic rituals to consecrate the army's maneuvers, he confesses that he "actually had no clue what the hell he was doing" (115); in truth, he is painfully separated from his ancestors' spiritualism because of his indoctrination into the UE forces. His years of service leave him unfulfilled, and he realizes that he "desperately needed to be part of a world that made sense. One that didn't snatch children from the rubble to die on some distant, cold rock. The ancestors. They called for his embrace" (116). He finds solace in mythic African figures. One is Oya Iyatunde Kosi Iku, an old woman who is "sparking a movement, rekindling spirits long thought dead," and revealing to Mbili that the ancestors are invulnerable to the destruction of the UE (118). Another is an old man in a waking vision who mysteriously removes the bombs from the Brain2s of Mbili, Barber, and their fellow “Nig," Jess. Mbili's and Barber's doubts about the UE inversely correlate to their faith in subaltern religions, and they reject the war machine in favor of self-determination, as the veteran-rebels of Elysia have done.

Thus, the novel demonstrates that beliefs in non-materialistic ideologies can be foundations of resistance to the violent totalitarianism of the UE's capitalistic empire. Mr. Campbell explained to me, "I definitely did want to center around faith as a means of rebellion. 
Mbili, the woman with the saints playing cards, and Hank Kpa all embrace a faith in order to rebel against the current order" ("Re: Sunshine"). In this way, the soldiers' struggles against the army that enslaves them recalls important slave liberation movements of western culture. In Biblical legend, the story of Exodus centers around the Jewish people's faith that their God and their spiritual leader, Moses, would deliver them from Egyptian slavery. Likewise, AfricanAmerican spirituals represent how the enslaved blacks of the antebellum United States relied on their faith to endure the hardships of slavery. In Campbell's novel, soldiers are not enslaved because of their race but through their military service; and their faith, whether in the Gaia-like force of The Be or in one's ancestral religion, has real and potent effects which prove more powerful than the advanced technology of the UE.

The marvelous space of Sunshine Patriots allows the "magic" of The Be and African spirituality to exist alongside the technoscientific advances of the UE military. This dramatizes how the interplay of historical time participates in mythmaking, in that the past affects the future, and our visions of the future affect our present. Ultimately this extrapolated future exposes the excesses, hypocrisies, and absurdity of the attempt to control the globe under a banner of compulsory "freedom." Campbell's future vision is no more real than the spirit magic of the past, nor any more real than the myths used to propagate war. But these myths help to shape our perception of the material world, and they can lead to real material effects, like the decision to go to war, or the decision to end it.

\section{Conclusion: Grand Myths of War and Peace}

These novels might seem far removed from our present reality, but both are the products of their authors' critical assessments of the direction of American militarism. ${ }^{1}$ Stacewicz 
explains that the Vietnam antiwar movement is best understood within the historical context of the United States' rise "to global hegemony after World War II and the efforts of its foreign policy makers to maintain hegemony at any cost” (418). Haldeman and Campbell recognize this context as well, and their mythscapes project the historical realities they witness into violent futures, providing a critical distance that fosters a more objective critique of our present as well as a justifiable fear about the direction of our militant ideologies. What if the cost of maintaining America's unquestioned hegemony is the sacrifice of the ideals we claim to hold most dear? In a recent issue of PMLA, Steven Schroeder questions "[t]he pervasiveness of the assumption that war is necessary" and wonders "whether and how we might cultivate judgment that is intuitively opposed to war rather than intuitively resigned to it" (1690, emphasis in original). These American authors break the alleged consensus of this nation's stance on war, proving that not all Americans are convinced our wars are necessary and giving ample reasons why we should be opposed to war, not only because of the damage to other nations and our soldiers but because of the irrevocable harm to our nation's character.

While these mythscapes are rife with bloodshed, their true purposes are profoundly antiwar. They exploit the popularity of fictional violence to embed potent arguments against imperialist war. The excessive violence inflicted under the auspices of these futuristic ideologies — grossly extrapolated from present modes of aggression—compels readers to reflect on the real violence caused by our own seemingly noble ideologies, particularly the supposed "freedom" we attempt to force upon weaker nations. By setting these wars in the distant future, the mythscapes suggest that such ideologies will continue to dehumanize us to unreal degrees and alienate us from our ambitious pursuits of universal justice and true democracy. High-tech wars of imperialism are, moreover, hazardous to both our enemies and our soldiers, as these 
novels attempt to demonstrate. Despite the pessimism pervading these violent narratives, both novels end on positive notes: Mandella marries Marygay in post-war peace, and Barber escapes his condemned prison cell via the magic of The Be. These conclusions imply that a state of endless, far-flung war is not yet guaranteed, and that citizens of a democracy can reject war, as these protagonists - and their authors - have done. If the grand myth of the necessity for endless war creates these dystopian futures, then shattering that myth will bring us closer to believing in the necessity of peace.

\footnotetext{
${ }^{1}$ Other authors construct futuristic mythscapes designed to challenge the grand myth that pre-emptive, imperialistic wars are necessary. In The Word for World is Forest (1972), Ursula Le Guin transplants the imperialistic war against the Vietnamese to a distant planet, where capitalistic ventures led by the human invaders from Earth threaten to devastate the peaceful natives of the planet Athshe; she characterizes the Terrans' invasion as greedy and exploitative while simultaneously generating sympathy for the Athsheans' struggle of liberation. James Cameron's Avatar (2009) has disseminated, via the popular medium of 3-D cinema, a narrative in which the technologically superior military of an imperialistic future Earth is repelled by an indigenous people united by faith and the determination to protect their homeland.
} 


\section{Chapter 4: The "Wild West" and the "New Weird"}

The so-called New Weird subgenre of speculative fiction is known for its uninhibited commingling of fictional genres, most prominently science fiction, fantasy, horror, and steampunk. Recent novels by two New Weird innovators, K. J. Bishop's The Etched City (2003) and China Miéville's Iron Council (2004), also feature clearly recognizable motifs from the genre of the Western: deserts, gunfights, outlaws, railroads, ghost towns, etc. Transplanted from their actual historical contexts into marvelous settings, these motifs become starker, almost parodic. The Western represents a distinctly American milieu, and as such, refiguring its characteristic elements in politically aware postmodern fiction simultaneously glorifies and critiques certain fundamental aspects of American culture. The displaced generic elements of the Western often glorify American ingenuity, individualism, bravery, and optimism. Yet at the same time, they tend to critique capitalism, gratuitous violence, despoliation of nature, and devastation of indigenous peoples.

This chapter examines how these novels by Bishop and Miéville utilize the violent scenes, harsh settings, and American roots of the Western genre as provocative inroads into broader issues of identity and social change. First, I will outline the implications of depicting Western tropes, especially the genre's archetypal desert setting, in the twenty-first century. I will then define the New Weird and assess how the Western fits in with this multifaceted genre. My reading of The Etched City explores the roles that place and gender play in transforming the personal identity of its protagonist, who strives to resist the violence characteristic of the Western and the New Weird. My reading of Iron Council evaluates the tribulations of collective revolution within a hostile setting via the manipulation of technologies (represented by the train) which can serve beneficial or malicious ends. The weirdness of the New Weird, with its invented 
worlds and supernatural effects, estranges readers from the violence, settings, and personae characteristic of the Western, compelling them to interrogate these elements of a genre which is so deeply embedded in the American mythos.

\section{Building a Mythscape on Western Soil}

Despite its easily recognized imagery and often formulaic conventions, the Western is a deceptively complex genre. This is at least partly because the narrative spaces (using de Certeau's terminology) of the genre are inflected by a nebulous dialectic between the places and histories of the real American West and the many myths that have been created about it. Further, the long-running popularity of Western fiction has ensured that the fictional narratives themselves also continually engage in this dialectic. Even out of geographical context, as in New Weird fiction, the "codes and images" which act as generic markers of the Western, such as "the lonesome hero, moral justice enforced by violence, the coming of the railroad, the shoot-out, the open prairie, hats, horses, cowboys, and guns" (Turner 218), bear traces of their American roots. ${ }^{1}$ Bishop and Miéville are both non-American authors-they are Australian and British, respectively - who deploy the tropes of this distinctly American genre in the new millennium, raising questions about the Western's relevance in twenty-first century global discourse.

Perhaps the popular perception of the administration of George W. Bush has triggered some renewed fascination with Western themes. Articles from around the world during his 20002008 administration refer to Bush's "cowboy diplomacy" or to his characterization as a “cowboy." For example, Paul Harris, writing for London's Daily Mail, pokes fun at "Dubya's" cowboy boots and matching diplomacy: "there would probably be a lot of pacing around with Tony Blair before [Bush] could ride triumphantly into the sunset — the kind of talks for which a 
man definitely needs his favourite boots" (13). Bush's own language does, at times, suggest that the title "cowboy President" fits him well. His famous declaration that Americans would "smoke [Al Qaeda] outta their holes" and that Osama bin Laden is "wanted dead or alive" (qtd. in Keller 256) recall scenes of cowboys hunting bandits in a Western. In an address to Australian Parliament, in which he attempts-between interruptions by disgruntled Senators-to cull support for his "War on Terror," he begins with a folksy comment about meeting the Prime Minister at his Texas ranch (cited in Hannity and Colmes par. 2). He consciously, carefully constructs a Texas persona for himself, as he did before and during his Presidency. In a speech just before his inauguration, "Bush made it clear he will always be a Texan... 'I wanted to remind people I would never forget where I come from. Texas. That's my address, whenever this journey ends"” (qtd. in Attlesey par. 32-4). Yet his cowboyish swagger is an affectation, for Bush was raised not as a ranch hand in Texas but as a scion of a wealthy family in New England.

But prior to Bush the Younger, Ronald Reagan also used cowboyish language and attitudes to characterize himself, as Alexandra Keller makes clear (253-4). Indeed, the appeal of Western iconography runs deep in American rhetoric and rhetoric about Americans. Frederick Jackson Turner, an American who helped to shape the country's perception of the frontier in the late 1800 s, "attributed to the West the responsibility for virtually every American virtue or vice" (Kolodny 136). International myths about the United States tend to assume its national identity is fundamentally Western (Worster 34). Such generalizations blur the distinct regionalization of the United States and broadly characterize its posture on the world stage. According to Stanley Corkin, the renewed popularity of the Western after the Second World War suggests that the frontier myth, "a quintessential American legacy" (67), is complicit in U.S. global dominance because "the western has the mythic power to define the past as a triumphal moment when a 
compendium of quintessentially American traditions took hold" (68). International myths of America have become entwined with myths of its West, as if Manifest Destiny has been carried over into certain global discourses.

Some myths about the American West exult the region as a utopia waiting to be created. Worster explains how the idealism of westward expansion led settlers on the frontier to believe that they were leaving all evil behind them in the East, assuming that the allegedly pristine land promised an incorruptible society: "This flawless West must be kept in precious isolation, removed from the contaminations of history and the world community" (7). In West of Everything (1992), Jane Tompkins also describes the rather starry-eyed optimism surrounding the West, writing that the "West functions as a symbol of freedom, and of the opportunity for conquest. It seems to offer escape from the conditions of life in modern industrial society.... The desire to change places also signals a powerful need for self-transformation" (4). Utopian myths of the West are gilded with notions of personal and cultural transformation, ideas which are addressed in detail in the New Weird fictions below.

The geography of the real West is obviously a crucial part of the Western mythos, and the archetypal desert setting reinforces the idea that locations can be transformative. At its most basic, the desert in literature represents deprivation (Lutwack 31), but it can also symbolize an individual's "deep alienation from one's surroundings" (200). Conversely, the desert could represent one's alienation from civilization. Edward Abbey embraces the desert's resistance to habitation, believing that its apparent emptiness is its appeal (22) and relishing the idea that such harsh environments will remain wildernesses to which free people can escape for refuge from authoritarianism (231). Yet as a brutal, unforgiving place, the desert tests anyone venturing into it; the motif of the desert as a site for formative spiritual journeys is important to Biblical 
mythology, as when Moses leads the Israelites out of Egypt (Exodus 13-17), and Jesus ventures into the desert to be tempted by Satan (Luke 4:1-14). Both novels examined here deploy this trope of crossing the desert wilderness as a test that the protagonists must overcome to succeed at their goals, whether personal or political.

The wealth of myths about the West inform the creation and reception of the Western genre, and many postmodern authors mimicking Western tropes or writing actual Westerns manipulate the genre's elements with a critical eye towards its distinctly American origins. In Frontiers Past and Future: Science Fiction and the American West (2006), Carl Abbot analyzes how Western imagery in American science fiction “probes the meaning of the nation's past as well as its future" (28). Postmodern Westerns often attempt to understand the troubled past of the American West in ways that are meaningful and relevant to present discourses of race, imperialism, and American hegemony. ${ }^{2}$

New Weird authors also participate in this literary response. Ann and Jeff Vandermeer's The New Weird (2008), an anthology of short fiction and essays on the subject, traces the New Weird's origins from the "weird" fiction of modernist authors like H. P. Lovecraft, a name that has become synonymous with weird fiction. "“Weird' refers to the sometimes supernatural or fantastical element of unease" that characterizes weird fiction (Vandermeer ix), and Lovecraft frequently exploited this sense of discomfort in his characterizations of the racial or alien Other. This mood of unease has influenced many modern horror writers and lends itself well to the genre-blending, ambiguous nature of the New Weird, which builds on the sensibilities of weird fiction but takes them in bold new directions. Sherryl Vint describes New Weird as "as a blend of science fiction, Surrealism, fantasy, magical realism, and Lovecraftian horror" that "reinvigorates fantastic writing" by avoiding the "tired tropes and themes" found in the pseudo- 
medieval realms often associated with genre fantasy (197). The New Weird revamps fantasy literature by challenging literary prejudices about "genre" fiction itself by being as allusive and lexically sophisticated as other "literary" works. Setting is also important to New Weird fiction. Vandermeer defines it as "a type of urban, secondary-world fiction that subverts the romanticized ideas about place found in traditional fantasy," relying instead on "complex realworld models" for its settings and creating a tone that is visceral and contemporary (xvi). The idea that New Weird fiction mimics real-world places is particularly relevant to a discussion of Westerns, which inevitably recall actual locations.

New Weird fiction also contains a noticeable "political dimension," as Alice Davies notes (7), and this grounds the genre in contemporary discourses and ensures a rhetorical edge appropriate for a mythscape. Bishop proposes that the New Weird is characterized by a metanarrative awareness, that is, "a tendency to thin or vandalise the fourth wall while generally, though not always, stopping short of knocking it down" ("Whose Words You Wear," 347), which encourages readings that are fully conscious of the author's contemporary world. The term "Radical Fantasy" may be an appropriate term for describing the fiction of authors like Miéville and Bishop, perhaps because it suggests a more politically engaged literature. William J. Burling writes that Radical Fantasy ${ }^{3}$ rejects the formal limitations of realism as well as the clichéd conventions of traditional fantasy to envision "militant, material struggles for progressive social justice and economic equality" in a fully detailed, "specifically historical" alternate world grounded in real-world concerns of late postmodernism (Burling 330-1). Like the mythical West, Radical Fantasy "projects a progressive, collective utopian impulse" in which "conflict is resolved by a progressive and 'forward looking' solution” (Burling 332). Radical Fantasy or New Weird fiction is also subversive, and not only because it subverts genre conventions. 
Because of its unabashed violence, depiction of human abnormalities, the presence of other intelligent alien species, its "grotesquerie" (Malcolm-Clarke 339), and impossible situations, it disturbs the reader, which Rosemary Jackson asserts is a necessary consequence for any text to be considered subversive (23).

So when the New Weird and the Western are combined, compelling patterns and contrasts become apparent. Both genres are known for graphic violence, but with the Western elements in place, the New Weird taps into Richard Slotkin's notion of regenerative violence in frontier life as a means of personal and social change (cited in Busby 86). By placing the action within an archetypal Western desert, these narratives venture out of the New Weird's "conventional" pseudo-medieval urban setting, though in both novels, city settings are also crucial. The interplay between such starkly different settings brings to mind issues of nature vs. culture, solitude vs. civilization, New World vs. Old World, and first-world vs. third-world, making the fictions relevant to current discourses of postcolonialism, environmentalism, and globalism. Because these stories are set in some far-flung corner of the universe, they implicitly universalize American concerns and myths, just as science fiction narratives with Western elements establish a "context of continuous European-American expansion" into the distant future (Abbott 19). Bishop and Miéville make the Western weird, not comfortable, by excising it from its original region and intermingling it with elements of the supernatural and alien. Without direct references to a past we cannot change, readers are provoked to examine the Western tropes for insights into America's violent past as well as our current selves and collective futures.

\section{Bishop's The Etched City}

Part One of K.J. Bishop's debut novel is set in Copper Country, a desert region on a 
fictitious world much like our own, and this section contains the majority of the narrative's Western tropes. Raule, the protagonist, is an itinerant medic who roams the inhospitable region, ostensibly aiding the inhabitants of remote villages. She is actually on the run from an army that is scouring the countryside for failed revolutionaries ${ }^{4}$ like herself and Gwynn, an outlaw and former compatriot of Raule's. Gwynn and Raule run into each other in a dusty town, where they agree to travel together in order to sell some arms that Gwynn had looted. But soon they are followed by enemy soldiers, and they must make a final stand at the gate of a ruined city, where they slaughter all of their pursuers. Raule then has an epiphany in which she yearns to live in a place where she can "become a civilised person" (Bishop 49), leaving behind her revolutionary life and all its violence. So she and Gwynn hide away on a train that takes them to Ashamoil, an urban-fantastic setting. Part Two chronicles her life as a surgeon in this city, juxtaposed to Gwynn's new occupation as a mercenary for a crime boss. The scenes in Ashamoil contain many of the text's New Weird conventions: pseudo-medieval urban setting, grotesque deformities, the supernatural, etc. The contrast between the two archetypal settings - the Western desert and the New Weird city—complements the gendered contrast between the two main characters, testing how each acts in solitude and deprivation vs. society and abundance: Raule becomes increasingly compassionate while Gwynn becomes increasingly cruel.

From the outset, Bishop provides the reader with numerous images indicative of the Western genre. In a run-down saloon, Raule sees "four men sitting at cards around a table crowded with bottles, glasses, and piles of banknotes. All four were clad in sombre-coloured outfits, decked out with weapons and ammunition bandoliers, and wore wide-brimmed hats that hid their features in shadow" (5). The description self-consciously reveals its manipulation of genre tropes, describing how one player is wearing a bandana over his face like "a graphic 
caricature of a ne'er-do-well" (5). Like the seedy poker games found in countless Westerns, this archetypal game becomes a shortcut to disproportionate violence. Soon, the bandana-wearing bandit is accused of cheating, and he guns down his opponents, leaving the reader with a snapshot of a classic Western: "Only the veiled man was standing, wreathed in gunsmoke, lit by a cat's cradle of thin sunbeams threading through new bullet holes in the walls and roof. $\mathrm{He}$ reloaded the pair of long-barrelled revolvers he had in hand and holstered them" (7). This man turns out to be Gwynn, who acts as a foil to Raule throughout the text. Here he commits the first of many acts of violence, and although Raule takes it in stride, her resolution to eschew violence in the future is constantly affronted by Gwynn's readiness to commit it.

Gwynn is also a former revolutionary, though he is now defiantly proud of his role as an outlaw whose likeness appears on wanted posters throughout the country (9). Like a legend of the real Wild West, Gwynn is amused by "the disparity between the grandeur that myth demanded of a famous man's life and death, and the bathos and indignities that actual circumstances tended to force upon both" (9). This line recalls the combination of myth and reality that Henry Nash Smith describes as the "literary development of the Wild Western hero" and how difficult it became to separate the tall tales from the facts about such heroes as Crockett, Carson, and Cody (103). Once, he was an idealist like Raule, but since the failed revolution he has become an opportunistic gunslinger. He seems to enjoy being a dangerous loner on the wrong side of the law, like a version of the "prototype of American masculinity-the cowboy" (Worden 35). Raule, in contrast, has grown tired of a life of running and fighting. Her decision to reject this "masculine" life and pursue a more wholesome path as a physician in the city, contrasted with Gwynn's violent lifestyle, forms the central dynamic of the novel. The change of setting between Copper Country and Ashamoil helps to precipitate the characters' personal 
changes, and in light of their gender differences, the narrative interrogates how region and sexuality can impact one's moral development.

\section{The Archetypal Western Setting and Character Development}

The fictional expanse of desert known as Copper Country is geographically similar to certain regions of the American southwest: "In the south of the country, arid scrubby plains alternated with stretches of desert. One road crossed this region, connecting the infrequent hamlets and oases" (Bishop 1). Towns in Copper Country have names like Proof Rock (4), Yellow Clay (15), and Patience (16), a nomenclature that mirrors places in Texas, such as Granite Shoals, Red Springs, or Necessity. The desert appears strange and mythic because of its geological appearance, such as "several miles marked by low hillocks of pale stony rubble, strewn around as if a celestial kiln shelf full of giant unfired clay pots had been hurled down upon the earth by a choleric brother of the lazy god" (29). This "alien territory," described as "empty and dry as a thousand-year-old skull" (30), is no less bizarre than, say, the Badlands of South Dakota. Yet by transplanting a Western-style to a weird planet, the "plains and desert are thus made boundless in their possibilities and dangers extended to the ends of the imagination" (Abbott 100).

Like a desert in a Western, Copper Country tests those who pass through it with its unrelenting, personified brutality. When the sun glares down overhead, "Raule had a sense of being pitted against an inimical force" (Bishop 29). At one point the protagonist imagines the land addressing her directly: "She sensed the wasteland mocking her. You too will be burned and broken and rendered down to dust, it seemed to taunt" (Bishop 30, emphasis in original). This perceived interplay between the character and the setting recalls Tompkins's phrasing of the 
Western desert as a testing ground for would-be heroes (71). But instead of hardening her to more violence, as in a typical Western, Raule's desert crossing has the opposite effect: it helps to purify her of her violent past. While assessing Mark Twain's Roughing It, Patricia Nelson Limerick notes that "desert monotony suggested to Clemens a version of death-in-life, a helpless entrapment in sameness" (73). A similar notion seems to affect Raule after her years of wandering the desert. To change herself, she realizes, she decides to change her surroundings. Raule resolves "to leave Copper Country and travel far away. She wished to bind herself inextricably into a place where she could become a civilised person, and remain so for the rest of her life" (49). Even though the desert is her ancestral home, at this point in the narrative she believes the colonial myth that civilization is the cure for her dissatisfaction and the prime location for her career as a healer.

She comes to this realization after her desert ordeal strands her and Gwynn in a ruined city where they ambush their pursuers with dynamite. There are many ruins "at distant intervals" along the road, like "the remains of watchtowers and small forts" (1). Now that this land's native population—Raule's people — has been subjugated, the towers and defensive outposts had become obsolete and fallen into ruin. The characters also come upon "a ghost town huddled around an abandoned mine" (15), a marker of economic obsolescence as well as natural exploitation. Ruins in literature are "places consecrated by the great events in the history of mankind that once occurred there," and they provide "tangible witness of the past" (Lutwack 55); these ruins disclose Copper Country's history of violence and hardscrabble living, and they suggest both the fragility of human life and the impermanent, cyclic nature of our civilizations, as their presence in the feminist post-apocalyptic novels demonstrates in Chapter Two. Such desert ruins recall the Native American civilizations that once throve in the Southwest, 
particularly the Anasazi, whose cliff-dwellings remain long after the people had gone.

Raule is deeply affected by the ruins, particularly the formerly great city in which she and Gwynn defeat the soldiers who are hunting them. She views the ruined city as "a damaged puzzle" and, although it seems "devoid of information about the city's past and its people," Raule struggles to imagine the people who must have dwelt there eons ago (39). As she muses, [a] hollow, uneasy emotion grew in her, as old dreams visited her mind. She recalled her childhood wish to become an eminent physician, and remembered imagining the discoveries she would make about sickness and health, life and death. She identified the hollow feeling: it was mourning, for the loss of time and the loss of something of herself, perhaps a great deal of herself....At last, standing exposed to the dark and the wind, she abruptly and deeply regretted joining the revolution and supporting the violence that marked her true aspirations. (40) Such introspection creates in Raule the feeling of unease characteristic of weird fiction, yet the nostalgia is characteristic of the Western. This scene, in which the desert setting and Western nostalgia coalesces with the unease and political consciousness of the New Weird, is crucial to the narrative because Raule discovers a character-changing conviction here. She sees her involvement in the revolution — the details of which are vague — as one of ultimate futility in this place where all of humanity's accomplishments are dust. After she and Gwynn kill an entire platoon of vengeful enemy soldiers, Raule realizes that such bloodshed is not worth the cost of revolution, so she resolves to withdraw from the collective action and work towards personal change instead.

In addition to highlighting how changes of setting can foster character development, the Western elements of the novel can be useful for interpreting the gender differences between the 
two main characters. Tompkins asserts that there are "classic oppositions from which all Westerns derive their meaning: parlor versus mesa, East versus West, woman versus man, illusion versus truth, words versus things" (48). Through the juxtaposition of its two main characters, Bishop's novel maps out another opposition, (female) physician versus (male) thug. Gwynn represents the "masculine" stereotype of the violent gunslinger, a skilled shooter who can calmly gun down anyone who stands in his way and look picturesque doing it. Raule, on the other hand, consciously chooses the vocation of one who heals wounds such as those caused by her former compatriot's actions. Raule becomes increasingly disgusted with Gwynn, especially when she must deal directly with the consequences of his mobster lifestyle: she is coerced by Gwynn's criminal employer to act as "surgical advisor" to a grueling execution, performed with sadistic relish by Gwynn (Bishop 291-2). Tompkins writes that "the genre exists in order to provide a justification for violence" and describes how Western protagonists frequently endure repeated injustices before they are compelled to take bloody revenge which, by the plot's climax, "feels biologically necessary" (227-8). While Gwynn indulges in such violence, Raule becomes, in essence, a conscientious objector to the genre who maintains her pacifistic position for the remainder of the novel. Both characters, man and woman, have proven themselves capable of inflicting violence, but Gwynn is a slave to his greed and bloodlust, reaping the violence he has sown, while Raule eventually finds happiness in her self-deterministic pacifism.

Both Gwynn and Raule leave the city behind in the epilogue. Gwynn is killed by a man whose wife he murdered for his boss, but he is miraculously resurrected by his friend, a defrocked priest who sacrifices his own life to save the villainous mercenary (Bishop 364); this is one of the supernatural elements in the city that signifies the presence of the New Weird. He then goes to another city where "crimes were tried not in courts but in the theatres" (378) and 
from there his fate is obscure: the narrative provides numerous possible endings, from mundane to fantastic, that suit his role as a legend (380-1). Raule returns to her desert home now that she is no longer a wanted criminal and joins up with a nomadic tribe, where "gradually she became respected as a witch doctor among them. And in those years she rebuilt a core to replace the one she had lost—grain by grain, and in much different form" (377). This ending makes something of an essentialist argument of identity: by putting her original goals on hold to aid the revolution and then trying to fit into a strange and corrupt city because of her misconceptions about civilization, she is characterized as having "lost" some of her original essence—her "core"which is rebuilt in terms that suggest the sand of an hourglass or the sandy terrain of her homeland. Raule returns to her roots and pursues her goal of being a healer in a form she did not initially intend, while her dream of being a "civilised" person for the rest of her days proves futile because she has come to realize that the city is as savage and as violent as the desert, if not more so.

The contrasting settings in the novel emphasize the interplay between New Weird and Western: the former is represented by the city, and latter by the desert, and both are intractably violent, though the desert is hostile by nature, while the city's violence is a result of humankind's vices. Despite the heroine's goal to change herself by changing her setting, she learns to harden her resolve so that her environment does not change her, as when the city's violence threatens her pacifism. Raule's narrative ends with her figuratively riding into the sunset with her nomadic people, feeling like she is part of "a new, more gracious state" (377). She endures a trial by fire in the city so that she can return to her desert home, a reversal of the "city slicker" motif of the classic Western, made more weird by the fact that the woman, not the man, rides into the sunset. Like Edward Abbey, Raule embraces the desert life because she has been alienated from 
civilization; yet unlike Abbey, there she finds a community where she does not need to compromise her values in order to coexist peacefully. The Western mode is made ambiguousthat is, Weird — by this ending because she is not a traveler through the desert but a native of a strange red desert returning home, settling down, as it were, as a nomad.

\section{Miéville's Iron Council}

The Iron Council is a train, essentially a nomadic town, that was seized by its workers years ago and has since traversed the wilderness as a legendary symbol of hope to the oppressed citizens of New Crubozon, Miéville's iconic metropolis (and the setting of Perdido Street Station [2000], considered by many ${ }^{5}$ to be flashpoint of the New Weird's emergence). The Council builds new tracks from the old tracks behind it and thus perpetually avoids capture by the authorities and the Transcontinental Railroad Trust (TRT), the corporation that once owned the railroad. Multiple protagonists align themselves with the Iron Council, including Judah Lowe, a maker of golems ${ }^{6}$ (automatons composed of inanimate materials like clay or metal) who once worked for the TRT but later helped to overthrow it and form the Council; Cutter, a shopkeeper from New Crobuzon who trails his sometime lover Judah across the wilderness; Ori, a political activist living in the city who assists in the assassination of its mayor; and Ann-Hari, a former prostitute who is now the matriarch of the Iron Council. Together, they constitute the "collective political class protagonist" found in Miéville's novels (Burling 335). Although all of these characters work towards the Council's goals, they have differing personal agendas that cause tension amidst the novel's central conflict between the progressive Council and the repressive, capitalistic powers in the city. Western tropes, particularly the train robbery, the violent standoff, and the conquest of the frontier, help to dramatize the difficulties of working with a radical 
collective to fight for social change in a hostile backdrop, whether it is the desert wilderness or the regime of capitalism represented by New Crobuzon, while the New Weird tropes manifest in the strange creatures, city politics, ambiguous ending, and the supernatural powers of Judah and other characters.

The novel begins with Cutter and his friends following after Judah, who has gone in search of the elusive Iron Council. Judah once worked for the Transcontinental Railroad Trust but became disillusioned with its corporate ambitions when the railroad devastated the home of the stiltspear, a native tribe of intelligent swamp creatures. He helped to seize the train from the TRT, which led to the birth of the Iron Council, but soon decided to return to the city to tell the oppressed people there of the Council's victory. Years later, in the present time of the novel, the saga of the Council has practically become a myth. But the corruption in the city has gotten so dire, at least partially because of a costly war with the distant nation of Tesh, that Judah seeks out the Iron Council once more to see if they can aid the revolution of the oppressed. Cutter catches up with Judah just before they find the Council, which is now led by Ann-Hari. The Council stands up to the vengeful militia pursuing it and then attempts to return to New Crobuzon as a triumphant symbol of subaltern empowerment.

In addition to the train, there are numerous other signposts that indicate the Western's presence in this novel. There is an archetypal ghost town: "It was empty. The windows were only holes. The big doorways gaped into silent interiors" (Miéville 32). Like the ruins in Bishop's novel, this ghost town signifies the presence of civilization's bygone dreams and ambitions, as in the real West, when capitalistic quests for gold or industry witnessed the birth of countless towns; it suggests that materialistic goals are fleeting and ultimately empty. Later, a character enters the narrative and is immediately recognizable to anyone who has ever read or seen a 
Western. As a mysterious horseman approaches Cutter and his gang, he "nodded at them, touching the front of his brimmed hat. He was the colour of dust. His jerkin sun-bleached, his trousers of buck leather and the chaps smoking with dirt....On each hip he wore a pepperpot revolver" (Miéville 44). A brimmed hat, chaps, leather, and a pair of revolvers: this man, Drogon, has all the accoutrements of the archetypal cowboy. However, he is also "weird" because he has the supernatural ability to throw his voice across great distances. Drogon seems to be a cowboy, but the New Weird mode complicates this Western icon by making him capable of superhuman powers, recalling the exaggerated legends of real-life cowboys like Buffalo Bill or even Hollywood icons like John Wayne. In a Weird Western, the legends about the cowboy can be true, though unlike the archetype of the good guy in a white hat, Drogon's motives are mysterious: we are uncertain what this man is capable of doing, morally and supernaturally. Much of the novel's action occurs in a desert-like wilderness similar to Bishop's Copper Country: an almost personified desert space that antagonizes the main characters as they seek out the Iron Council. There are "[m]erciless baked-clay hills, dust and sandtraps," with only "scraps of plantlife" (26). Trudging across this landscape, "Cutter had never suffered in so brute a sun" (27). Their torment in this hostile setting does not deter them, and for "[d]ays they rode through landscape that punished them with heat and plants like barbed wire" (30). Several of the travelers die in crossing the wilderness. Their struggles reinforce the notion that much hardship is necessary for the success of the revolutionary ideal of the Iron Council, and the desert tests their resolve.

This desert is depicted as alien and strange, similar to The Etched City's Copper Country, emphasizing the mythic qualities of the setting even in an invented world. Odd, fantastic creatures dwell there. There are "trees of hard and alien nature" (26), presumably unlike the trees 
of a more temperate (and pseudo-European) environment that might be taken for granted by the characters. In the desert's midst is the Cacotopic Stain, "a rift through which spilt great masses of the feral cancerous force, Torque. A badland beyond under-standing... Where monsters go and are born. Where the land, and the air, and time are sick" (Miéville 270). The term "badland," of course, reminds readers of actual places like The Badlands in South Dakota, a place that already seems otherworldly; that the Stain is "beyond understanding" reinforces the notion that our conceptions of real places are but jumping-off points for visualizing the limitless possibilities of the fictional space. Even the strange, inhospitable character of a real desert "unsettles, in its vacant presence, conventional patterns of thought developed within the precincts of cultivated life" (Beck 75). Part of the desert ordeal, then, consists of forcing these "civilized" interlopers from New Crobuzon to question their established urban culture and thought processes in order to initiate a mental change not unlike an aesthete fasting in the desert to gain enlightenment.

Ecocritic John Beck offers an interesting, if ambitious, claim about the American desert's symbolic role as a setting. Beck proposes that "the desert can increasingly be seen as representative of aspects of contemporary capitalism: a space without boundaries, unhindered and unregulated by old practices and habits" (65). As a Marxist, Miéville frequently writes fiction that confronts the deleterious effects of global capitalism: "Iron Council alludes to many historical movements of socialist and radical opposition," most notably, "the labor struggles that attended the coming of the railroad to the American West" (Freedman par. 7). Thus, Beck's claim sheds an allegorical light on Miéville's novel. The labor force in the narrative takes advantage of the lawless desert region to overpower their superiors and begin charting an unknown, radical course through the symbolic terrain of global capitalism. Unlike train robberies in traditional Westerns, however, these usurpers are not trying to cash in on ill-gotten gains but 
rather on an ideology, one that rejects the capitalistic ventures of New Crobuzon, with its exploitation of labor, disregard for indigenous peoples, and disproportionate gains for the wealthy, and this political consciousness reflects the novel's New Weird sensibilities.

\section{The Iron Council as Archetypal Railroad}

Miéville's fictitious train mirrors real-world uses of railroad technology, both in its overt similarities to railroads of the American West and its symbolic implications. Freedman notes how the name of the capitalist venture that originally owned the railway, the Transcontinental Railroad Trust, "instantly recalls the America of the Wild West" (par. 10). Weather Wrightby, head of the TRT, uses language that is reminiscent of Manifest Destiny: "- I have wanted this for decades... Twice I went west finding routes. Twice, sadly, I had to come back. There's a crossing that's still to be done" (Miéville 169). Similarly, the leader of a group of hunters foraging ahead of the railroad tells Judah, "[E]veryone of us is a missionary of a new church and there is nothing that will stop holy work" (Miéville 158). Wrightby's self-gratifying quest to build the longest railway in New Crobuzon history is couched in terms that make it seem inevitable, even divine. This language compels the workers to forge ahead regardless of the consequences, just as Manifest Destiny justified the conflicts that led to the completion of the continental United States.

There are other curious parallels to the real history as well as the legends surrounding the American railway. Some of the laborers working on the tracks are superhuman workers, "prodigious and respected cactus-men who can push a spike home in one blow" (Miéville 221), who, like the fabled John Henry, are racialized others whose strength and endurance far exceed that of their peers. Miéville's narration also acknowledges the environmental destruction the 
train leaves in its wake even after it has been seized by the workers who take up the tracks behind them. The railroad "cannot pass without indelible marks. It will take years of earth shucking and rock rabbits and rock foxes crisscrossing ruts with their own paths, years of rain and winds before the scab left by the perpetual train is gone" (Miéville 264). No matter where the train goes, its impact on the land and its people is long-lasting, like many capitalistic ventures that consume resources and land. This does lend it a certain tenacity as a symbol, though, whether it is used by the capitalist TRT or the pseudo-proletariat Iron Council.

Miéville's fantastic depictions also recall the unfortunate history of the devastation of indigenous peoples living in the railroad's path. The invented terms used to describe fictitious indigenes clearly echoes such terms describing Native Americans: cactus-people or cactacae are described as "braves with picks and heavy hatchets" (280), terms often associated with stereotyped Native American warriors. Further, Miéville's invented race of cactus-people take on a certain significance in this setting as anthropomorphized vegetation that is virtually a synecdoche for the Western setting. Other native inhabitants, the stiltspear, "revive a death-cult" in a desperate attempt to repel the railroad that is destroying their land, and in response, the railroad's powers-that-be offer "a reward on each pair of stiltspear hands" (163). Their "cult" in response to the destruction of their land and society recalls such Native American responses as the Wovoka Ghost Dance movement, ${ }^{7}$ and the bounty on hands is similar to genocidal rewards for Indian scalps. ${ }^{8}$ Judah has peaceful interactions with the stiltspear-in fact, he learned his golemetry from them — and the TRT's invasion of their land causes him to become disillusioned with this capitalist venture. In an attempt to assuage Judah's misgivings, another worker for the TRT railroad tells him, "I have in my time seen enough men go native. It's an affectation, son, whatever you think now... I will only tell you that history is coming, and your new tribe best 
move from its path"; in response, Judah cries, “This isn’t empty land!” (Miéville 159, emphasis added). Judah sounds like a sole advocate for these natives' rights, just as, for example, Bartolomé de las Casas was considered an early advocate of Native American rights (Baym et al 35). Clearly Judah's "going native" is not an affectation. His sympathy for the annihilated stiltspear initiates his rebellion against the TRT and all the injustices of New Crobuzon politics.

The train is a unique type of setting because of what it represents, but also because of its spatial dimensions and mobility. Marian Aguiar explains how the British colonial rule of India was aided by the railways both physically and symbolically. She writes that the train, as a symbol of civilization, helped to impose and justify colonial rule in 1800s India (71). In addition to imposing economic imperatives on the native population, the train's form and function symbolically imposed Western (British) notions, such as "concepts of linear space and time, notions of progress [,] binaries of interior and exterior, representations of the nation, and deterritorialization" (Aguiar 72). Materially, a train comprises a fixed place (the railway car) with its own "interior order" that moves through a number of terrains in an perpetually "changing exterior order" (80), and its "ability to reconstruct space and time through movement made it a primary space for the constitution of new identities" (Aguiar 73). The train car itself is, according to Michel de Certeau, a "rational utopia" because of its ability to simultaneously cross boundaries and remain a closed, autonomous system (qtd. in Aguiar 78). In the context of the novel, then, the railroad's symbolic functions as a setting are manifold: the labor force remakes its identity by taking control of their own destiny via the train; the train moves through an inhospitable terrain yet is protected from the dangers of the desert; and its passengers carry a utopian ideal for the city to which they seek to return. ${ }^{9}$

The Iron Council is a decidedly weird train because it is nomadic, recycling its rails as it 
moves, and it carries cyborg Remade, cactus-people, and so forth, in addition to a progressive ideology for the people of New Crobuzon. In The Machine in the Garden (1964), Leo Marx explains how the emergence of the railroad onto the American pastoral scene did not defile the national "garden," as contemporary environmentalists might assert, but instead heralded a new era of innovation and prosperity for the nation and, by extension, all democratic peoples. Such optimism regarding the symbolic import of the railroad is useful for approaching Miéville's figuration of the Iron Council. Marx describes $19^{\text {th }}$ century artists and authors who were inspired by the railroad and its creation of "a new mechanized landscape" capable of cultivating an "ideal state of mind" in which there is "unprecedented harmony between art and nature, city and country" (195). Similar to the West itself, the railroad came to represent American ingenuity, bravery, and democracy; some believed it even personified Americans (Marx 208). Marx describes how Daniel Webster perceived the railroad as a means to overcome regional barriers, promote the unity of the nation, and symbolize social equality as a means of transportation for rich and poor people (210). As the train gained influence as a national icon, it became "a transcendent symbol: a physical object invested with political and metaphysical ideality. It rolls across Europe and Asia, liberating the oppressed people of the Old World - a signal, in fact, for the salvation of mankind" (Marx 206). The Iron Council also attains this symbolic value for freeing the oppressed poor of New Crobuzon. When describing his admiration for the rebel train, one of Judah's compatriots confesses, “All I'll say is that word that the Iron Council was coming... well, it changed things. Even when we thought it was just a rumour, even when I thought it was a myth, it still felt like something was...it was different" (Miéville 472, emphasis in original). The power of the myth alone was enough to get the oppressed city dwellers to act, and this leads Judah to the realization that the Iron Council need not be martyred to have an 
effect. But Ann-Hari asserts that the Council must follow through on its promise to liberate the city: "We have a responsibility...We're a dream...The dream of the commons. Everything came to this, everything came here. We got to here. This is what we are. History's pushing us" (514). Her language ironically—and typifying the ambiguity of the New Weird — mimics the language of the capitalist adventurers who sought to build the railroad in the first place. Railways must tend to inspire grandiloquent speech about forward movement and the illusion of progress.

The revolutionary fervor of Ann-Hari and other veterans of the Council is stopped cold by Judah's decision to seal the train in a "time golem" just before it reaches the city (Miéville 541). This basically freezes the Council train and all of its passengers in that moment in time, so that they can neither act nor be harmed by anything outside their capsule. Judah does this because he is certain that when they reach the city, the Council will be slaughtered by the waiting militia. But Ann-Hari, who was outside of the train at the time, shoots him dead for robbing them of what she believes to be their destiny. She upbraids him, saying, "But we were never yours, Judah. We were something real, and we came in our time, and we made our decision, and it was not yours. Whether we were right or wrong, it was our history" (Miéville 552, emphasis in original). Like a vigilante cowboy, Judah acts unilaterally, trusting his own intuitions and imposing his will on the Council because he feels it is for their own good. Ann-Hari feels entitled to her revenge because she has been deeply wronged by Judah's decision, and in the Western milieu, vengeful slayings always seem justified. However, Judah's murder at the hands of his former lover, whether justifiable or not, seems tragic and senseless; the damage is already done, so Ann-Hari kills him out of anger, not to prevent the creation of the time golem. The Western cliché of the good guy gunning down the bad guy is overturned here: not only does a woman shoot a man, but it is morally ambiguous: who is right and who is wrong? Should the Council 
have gone on to its "fate" at the hands of the city militia? No one is wearing white hats or black hats to signify a clear moral standoff.

The value of Judah's fatal swan song is not immediately apparent, however. Why doesn't the narrative just allow for the revolutionaries to defeat the oppressive city-state? Such a bloody end seems more appropriate for a Western-themed narrative, with the good guys - the Councilgetting their revenge on the oppressive powers of New Crobuzon. Freedman proposes that "the temporal suspension that Judah effects also amounts, on a rather different level, to a metaphor for the preservation of revolutionary hope through such deeply unrevolutionary eras as that in which the novel itself is written" (par. 16). In other words, the opportunity for revolution may not seem very good in the neoconservative ' $00 \mathrm{~s}$, but perhaps when the time is right, the progressive spirit will emerge from its slumber. Birns claims that "as dramatic an ending as the Time Golem is, it is not a conclusion that corrals the audience. It can seem a gesture of the author throwing up his hands, less in resignation than in participatory solicitation" (207). He suggests that the novel itself is "a kind of time-golem" that does not directly map out one solution to social injustice but might be capable of "raising our consciousness to a higher level" (207). Perhaps this is true, because instead of the Iron Council giving the reader the satisfaction of closure by "saving" New Crobuzon from oppression, "It is always coming," as the last line of the novel proclaims (Miéville 564). This open-ended conclusion robs the reader of the catharsis of a successful revolution, as if Miéville is forcing us to hold on to the urgent feeling that something still remains to be done. He purposefully makes it difficult for the reader to leave the revolution behind after closing the book, instilling a New Weird ambiguity and estrangement that provokes thought rather than resolves neatly. 


\section{Conclusion: Why Revive the Old West for the New Weird?}

A number of significant parallels between these novels suggests much about the

rhetorical potential of the New Weird/Wild West mythscape. The Western milieu provides these authors with ready-made scenarios in which violence is a catalyst for personal and/or political action. Yet both authors contend with the issue of Slotkin's "regeneration through violence" as an important trope in American frontier mythology (qtd. in Busby 86). Bishop's protagonist consciously resists gratuitous, cinematic violence, depicted in her novel as unflinchingly as in hundreds of Hollywood movies; and Miéville critiques the violent conquest of the frontier required for building the railroad while exulting in the radical potential of the captured train. Both narratives are set in alternate worlds, but both are also about our own present: Worden explains how the HBO series Deadwood features an excess of profane language that connects its late 1800s Western setting to our present time (240). Likewise, Miéville's and Bishop's novels have their share of profanities and modern English dialogue ${ }^{10}$ that make them accessible to this decade's readers. Neither author attempts to make the language sound antiquated as if it were in a pseudo-medieval setting typical of fantasy fiction. This gives the novels an immediacy that does not relegate their plots to some mythic past, as is usually the case for nostalgic Westerns and traditional fantasy.

Both novels also foreground ideological conflicts between characters of different genders. Gwynn and Raule disagree strongly over their willingness to commit violent acts, while Judah and Ann-Hari argue vehemently over the destiny of the Iron Council. These gender-based oppositions - in which, in both novels, the women "win" - confront directly the Western stereotype of the woman, who, if she appears at all in a narrative, is usually a submissive damsel or a saucy whore, there to cheer on the cowboy or service his needs, but rarely to confront him as 
an equal. Unlike classic Westerns, in which the "domesticating woman" promotes an agenda of settling down that is anathema to the heroic cowboy (McDonough 107), Raule and Ann-Hari have complex agendas that are political, personal, and antagonistic to the male characters, which reflects the New Weird political consciousness more than the Western gender stereotypes.

When considering the multiple settings of these two novels, a curious similarity emerges: both narratives oscillate between a city (the archetypal setting of New Weird fiction) and a desert (the archetypal setting of the Western). Raule arrives at her resolution to become a healer in a metropolis while out in the desert, and she returns to the desert when city life proves unrepentantly hostile. Judah crosses the desert to bring the revolutionary Iron Council back to the unjust city. The juxtaposition of these two starkly different environs in each novel highlights the rhetoric of these mythscapes. Raymond Williams's famous ecocritical treatise, The Country and the City (1973), contains some insights into this issue: "Clearly the contrast of country and city is one of the major forms in which we become conscious of a central part of our experience and of the crises of our society" (289). The possessive pronouns in Williams's passage indicate what is at stake in the contrast between desert and city: Our experience is subjective and personal, whereas our society is collective and mutual; the former is most starkly imagined in the solitude of the desert, where the individual body is tested to its extremes, while the latter is best dramatized by the teeming city, where the social body is under the greatest pressure. The desert may be a site conducive to personal revelations, but the city is the ideal arena for fomenting social change.

Yet the New Weird mode, with its political consciousness and metanarrative awareness, encourages interpretations that extend beyond the borders of the fictional world and its characters. These starkly different places could be exclusive of each other-indeed, in both 
novels the city scenes are separated from the desert scenes from chapter and section breaks-but the pursuits of the protagonists bring them together. Raule and Judah are also not very alien, as their otherworld homes suggest, but have many traits that seem fitting for contemporary citizens of the global culture: they are both worldly, determined, innovative, and idealistic individuals, sure of their convictions, pushing the traditional boundaries of gender roles (Raule is a fiercely individualistic woman and former warrior, Judah is a bisexual man) in ways that are more postmodern than pseudo-medieval. We see traces of contemporary Americans and perhaps the novels' authors in these characters. Similarly, we see reflected in the recursive influence between city and desert the echoes of global capitalism, in which metropolises affect distant lands across the world and vice versa. The New Weird combined with the Western demonstrate how formerly distinct places and spaces are now mutual factors in a very large and very diverse heterocosm.

\footnotetext{
${ }^{1}$ John E. O'Connor and Peter C. Rollins stress this point in their introduction to Hollywood's West: "There is no more characteristic American art form than the Western film. Even when it is produced in Italy, Finland, East Germany, Hungary, Australia, or Japan, there is no mistaking the American institutions that are being represented or the distinctively American character types portrayed" (1).

${ }^{2}$ An example of a postmodern author writing a critical Western is Cormac McCarthy's Blood Meridian (1985), an unflinchingly brutal novel which exposes the racism and opportunism that allegedly justified the violence of both the fictional and the historical West. Consider also how Gran Torino, a 2009 movie set in contemporary suburbia, consciously manipulates its director and star Clint Eastwood's iconic status as a Western hero: he frequently spits rather than speaks, he points his finger like a six-shooter at gang members, he has a final stand-off on the gang's front lawn, etc.

${ }^{3}$ Burling always capitalizes the term, so I have done so here.

${ }^{4}$ This recalls a stock character type in some Westerns, like McCarthy's Blood Meridian, the film The Outlaw Josey Wales, etc., which feature ex-Confederate soldiers becoming wandering gunfighters in the West.

${ }^{5}$ See Davies 7 and Vandermeer ix.

${ }^{6}$ Freedman notes how Mieville's Judah is an allusion to Rabbi Judah Loew of Jewish legend, who built a golem to protect the Jews of $16^{\text {th }}$-century Prague (par. 16).

${ }^{7}$ See Leslie Marmon Silko's The Gardens in the Dunes (1999) for a fictional account of a Ghost Dance.

${ }^{8}$ See, for example, McCarthy's Blood Meridian.

${ }^{9}$ Aguiar also asserts that railways are "material evidence of modernity" (67) and that passenger trains are cyborgs, a "cross between a crowd and a machine" (77). Thus, their presence in the novel is a generic marker of modern technology more associated with science fiction than fantasy. Conventional fantasy favors a pseudo-medieval world in which magic takes the place of technology. So in addition to Miéville's broader goals for critiquing capitalism, he upsets the traditional order of the fantastic genre by foregrounding the presence of this machine.

${ }^{10}$ Technically New Crobuzon's primary language is Ragamoll, but the characters all speak in clear English without a metafictional hint of translation.
} 


\section{Chapter 5: The Surreal, Pornographic Worlds of Carter and Acker}

Angela Carter's The Infernal Desire Machines of Dr. Hoffman (1972) and Kathy Acker's Blood and Guts in High School (1978) are innovative postmodern novels which utilize surrealist imagery to depict pornographic scenes. Carter and Acker deploy the style, lexicon, and imagery of two traditionally misogynist discourses, pornography and Surrealism, to refashion them in ways that expose their politics while exploiting their penchant for subversion and shock. In doing so, they engage in the polarizing debates amongst feminists of the 1970 s and ' 80 s about censorship of pornography. They also write within and against the tradition of the romance novel, a stereotypical form of "women's fiction." Their novels construct mythscapes that reflect the lustful and not-entirely-stable minds of their protagonists. The presence of the marvelous in such spaces suggests that, rather than depicting heteronormative sexual fantasies, they explore the darker, irrational, mythic aspects of human sexuality. By evoking surreal pornographic fantasies that are aberrant, violent, and disturbing, Carter and Acker parody conventional romances as well as canonical literature to undermine patriarchal versions of gender relations, and their sexually-charged mythscapes unsettle the clichés of both male- and female-oriented sexual fantasies in an attempt to explode the paradigms of sexual representations and interrogate the violence inculcated into the culture that consumes them.

Surrealist pornographic mythscapes are designed more to disturb than to titillate. Judith Butler writes that disturbing works of art "call into question some of the fundamental concepts that undergird the notion of culture itself. These are disturbing and disorienting moments, precisely because we lose our moorings at these moments, do not always know how to locate ourselves, do not know what it is we have thought we have always known" (par. 18). Unlike representational (legal) pornography—which involves one or more consenting adults - the 
disturbing sexual scenes in these novels combine the taboo with the outlandish to complicate porn's pragmatic goal of arousal by initiating speculation on the nature of the human, the perverse, the ethics of sexuality, female oppression, and the relation between sexual representation and cultural revolution. Susan Gubar's analysis of male-authored surrealist "pornartgraphy" that foregrounds "the relationship between hostility and sexual desire" prompts her to question how we might view such texts if they were "the products of the female imagination" (740). My investigation of Infernal Desire Machines and Blood and Guts explores this question. Carter and Acker describe sex in graphic, vulgar terms, disproving the stereotype that women's descriptions of sexual fantasies tend to rely upon toned down, passive language

(see Kimmel and Plante 61-2). Through their surreal mythscapes, they attempt to do what Carter considers the duty of the "moral pornographer" (The Sadeian Woman, 19), who is "a terrorist of the imagination, a sexual guerilla whose purpose is to overturn our most basic notions of [sexual] relations" (21), assaulting clichés of sex and romance by placing them in mythic spaces that are at turns nightmarish and parodic. Further, by being allusive and lexically sophisticated, they appear to violate the distinction between "vulgar" literature and "literary" texts. Like the Surrealists, their dreamlike worlds are dramatic explorations of the often shocking and ugly aspects of human sexuality, for they believe that therein lie the energies for cultural revolution.

\section{The Feminist Porn Debate and Surrealist Pornography}

Debates over the censorship of pornography precipitated a significant schism amongst feminist camps in the 1970s and '80s. Gubar summarizes the opposing camps: civil libertarian feminists believe the struggle for sexual freedom must resist censorship in any form, whereas antiporn feminists contend that pornography infringes on women's freedom by representing- 
and allegedly promoting — violence against females (714). Pornography thus contributes to a pervasive, culturally entrenched sexism, as A.W. Eaton concludes: "we conceive of pornography's role in sexism on the model of a feedback loop: at the same time that inegalitarian pornography is the result of gender inequality, it also facilitates and accelerates this inequality, and it does so cumulatively" (715). Nicola Pitchford explains how some antiporn feminists follow a Baudrillardian line of reasoning about the lack of distinction between simulation and reality: for them, "[r] eading the simulation of porn equals reading porn equals standing by while real violence takes place" (163). She is skeptical of this interpretation, however, because it presupposes "a simple binary division" wherein even simulated porn always validates male power and always victimizes women (163-4). Such antiporn arguments also pose a moral equivocation between victimless reading and real victimization, and this is a rather slippery slope towards rationalizing the censorship of any violent texts.

Feminists are not the only ones who criticize the influence of pornographic material on culture. During the late 1960s, right-wing politicians in America, led by Senator Strom Thurmond, attacked pornography by claiming it contributed to the moral corruption of youth (Perlstein 287-288). The general crusade against pornography has led to some unlikely alliances: Ellen Willis argues that, by condemning all pornography outright, antiporn feminists also attempt to repress sexuality and deny women's desire, thus aiding the conservative forces feminists have long resisted (461-2). While antiporn feminists argue that women should not create porn because it inevitably objectifies and victimizes women through representation, “Acker's and Carter's novels continually emphasize the fact that women can't help participating in representation, especially sexual representation" (Pitchford 170, emphasis in original). Clearly Carter and Acker are at odds with the antiporn camp, but they are not entirely unsympathetic. By writing surreal 
pornography, Acker and Carter distance themselves from the conservative antiporn campaigns while retaining both Surrealism's and pornography's radical potential.

Because "the spot where the erotic usually overlaps with the discourse of power and possession [is] traditionally the realm of the pornographic" (Hutcheon 155), representations of sex are crucial to understanding the dynamics of power between the sexes at their most basic level. Used correctly, pornography can serve progressive ends: "Insofar as pornography glorifies male supremacy and sexual alienation, it is deeply reactionary. But in rejecting sexual repression and hypocrisy—which have inflicted even more damage on women than on men —it expresses a radical impulse" (Willis 464). Carter and Acker reject sexual repression by dramatizing the darkest desires of their protagonists, but they also critique human sexuality by depicting it as inherently violent and ultimately unfulfilling. Nevertheless, there is a certain tongue-in-cheek irony to their often grotesque sexual representations. Though these are not comic novels, some of their sexual situations are darkly humorous: for example, Carter's male characters dress up as giant phalluses while visiting a brothel, and Acker's Janey has a seedy affair with President Jimmy Carter. The absurdity of such episodes contributes to a progressive campaign against middle-class prudery and stoicism in regards to sexuality. Constance Penley describes how, historically, pornography and "bawdy humor" both undermine the entrenched power of religion and bourgeois sensibilities (318); thus, the parodic, sexually-graphic natures of these novels function doubly in such subversion.

Surrealist pornography aesthetically combines the radical potential of pornography with the explicitly radical goals of the Surrealist movement, founded in the 1920s. Despite the unfeminist tendencies of Surrealism, identified by Carter in her essay "The Alchemy of the Word" (Shaking a Leg, 512), it espoused certain ideologies that could benefit the later feminist 
revolution. Surrealist Georges Bataille is particularly notable for his radical representations of sex as challenges to the foundations of Judeo-Christian morality. Carter writes, "Bataille puts pornography squarely in the service of blasphemy. Transgression, outrage, sacrilege, liberation of the sense through erotic frenzy, and the symbolic murder of God" (Shaking a Leg, 68). Suleiman agrees that Bataille's transgressive writings have radical potential: "For Bataille, transgression was an 'inner experience' in which an individual...exceeded the bounds of rational, everyday behavior," resulting in a painful and pleasurable experience in which taboos are realized as they are violated (Subversive Intent, 75). After lamenting the Surrealists' misogyny, Carter praises what she finds appealing about the aesthetic: "Surrealist beauty is convulsive. That is, you feel it, you don't see it—it exists as an excitation of the nerves" (Shaking a Leg, 512). For Carter, the Surrealist aesthetic's strangeness is a thrilling liberation from the traditional and the mundane. Surrealism alienates the reader/viewer from the "normal," just as Brecht's spectacular theatre creates awareness of social injustice by alienating the audience from their comfortable preconceptions.

Although Surrealism may seem an anachronistic term to apply to feminist writers in the 1970s, in these particular novels, Carter and Acker seem to share similar aesthetics and radical goals of the Surrealists. Their pornographic scenes are almost always violent in some way; the Surrealists likewise harbor a "love of violence" in the service of "the liberation of mind and spirit" (Lewis 17). The novels' fluid manipulations of time and space, absurd situations, and impossible events seem to evoke a realm of dream or nightmare; similarly, the Surrealists are fascinated by "the unconscious, the dream, the fantastic, or the "marvelous"" (Lewis 19). Because the novels are set in real places on Earth (South America, Africa, New York, etc.) that are distorted by the intrusion of dreamlike possibilities, they recall Breton's desire to fuse the 
"two states of dream and reality, seemingly so contradictory," into "a kind of absolute reality, a surreality" (qtd. in Lewis 20). Carter and Acker's novels also juxtapose the literary-allusions, eloquent language, and so forth — with the vulgar, similar to how avant-garde artists challenge the bourgeois notion that "art" must be separated from the "praxis of life" (Bürger 50). And ultimately, all share a revolutionary fervor aimed at changing culture. The Surrealists believe, "Man has been too long stifled and inhibited by logic and rational thought," and in order "to liberate his mind," they seek to teach him "how to grasp the imaginative fantasies that lay hidden, even from himself" (Lewis 18). Surrealist pornography strives to depict the irrational, often unpleasant nature of sexual desire lurking in the subconscious to alienate and liberate readers from their conventional perceptions of sex and gender.

To do this, these novels construct tactical spaces in which to parodically imitate and critique the often unjust strategies of sexual representation in a patriarchal culture. (I'm borrowing de Certeau's terms to theorize how the novelists deploy imaginative space). The protagonists of both novels have picaresque journeys around the world during which they engage in many sexual exploits. The fictional space of the real world is rendered surreal, however, because of marvelous imaginations of the protagonists: the Desire Machines manifest the desires of Desiderio, however absurd or nightmarish; and the fertile but disturbed mind of Janey, reflected in her heterogeneous notebook style, seems to make dreams reality and ignore the mimetic constraints of time, plot, and location. Thus, both mythscapes would seem to be fluidly recursive maps of the protagonists' consciousnesses. These sexually-charged distortions of the real world are rife with allusions to myth and canonical literature, demonstrating how fiction contributes to and shapes conceptual illusions about sex and gender. Their mythscapes are battle zones in the war over sexual representation, and in them, Carter and Acker simultaneously 
subvert mainstream notions of sex and gender while exulting in the shock value of aberrant, impossible, taboo fantasies.

\section{Carter's The Infernal Desire Machines of Dr Hoffman}

In her 1972 novel The Infernal Desire Machines of Doctor Hoffman (IDMDH), Carter constructs a surrealistic world in which violent, aberrant sex exposes the discomfiting relationship between power and desire. The novel forces readers to imagine graphic sexual violence, and thus the reader is positioned "between the poles of voyeurism and its critique" and "between the states of being violated and of condoning violence" (Mikkonen 171). Each of Carter's individual chapters is a heterocosm of sorts that references literary genres, such as the Gothic novel, ethnographies, the writings of de Sade, Greek mythology, etc., and each is set in a recognizable fictional space that is distorted by the Desire Machines: there is a brothel featuring robotic and bestial prostitutes, for example, and a remote African jungle populated by centaurs. Each setting is also sexually charged, ensuring that the characters must witness or engage in lustful acts in every exotic locale. By rendering these generic settings surreal via the pervasive influence of the Desire Machines, Carter estranges readers from our familiar expectations of such genres; unlike in mimetic literature, any dream or nightmare could manifest in Carter's mythscape, exaggerating taboos to absurd dimensions and confronting readers with the violence and perversion inherent in human sexuality.

The overarching narrative is a picaresque tale in which the protagonist-narrator, Desiderio, travels across a landscape warped by Dr. Hoffman's Desire Machines in a quest to kill the Doctor and pursue his romance with the Doctor's polymorphic daughter, Albertina. The narrator describes a mundane city as the novel's starting point, a modern stand-in for thousands 
of others in mimetic literature that "was a solid, drab, yet not unfriendly city. It throve on business. It was prosperous. It was thickly, obtusely masculine" (Carter 15). This conventional setting is quickly destabilized by the near-ubiquitous presence of the Desire Machines, which "sent out a series of seismic vibrations which made great cracks in the hitherto immutable surface of the time and space equation we had informally formulated in order to realize our city" (17). Because these Machines disrupt empiricist realism by making hallucinations real, rendering constants like time and gravity inconstant, and generally creating a state of fantastic nightmare, the city's Minister needs to stop Hoffman to save his city. The Machines are the fictional generators of the Deleuzian assertion that "[e]verything revolves around desiring-production and the production of desire" (380) and like Anti-Oedipus, they subvert familiar conceptualizations of sanity and reality. Dr. Hoffman explains that these "reality modifying machines" work by transmitting codes that are embryonic forms of desire, and "[o]nce these undifferentiated yet apprehendable ideas of objectified desire reach a reciprocating object, the appearance is organically restructured by the desires subsisting in latency in the object itself' (Carter 211). In other words, they can mutate into whatever the perceiver desires - though not in a hedonistic, gratifying way: more often, perverse, surrealistic manifestations occur, like "revenants," "[c]loud palaces," "chanting pillars," "[g]iant heads" and so on (18). From this point on, Carter subjects her readers to a world where anything goes: "the city was no longer the conscious production of humanity; it had become the arbitrary realm of dream" (18), a mythscape which explicitly foregrounds the aesthetics of Surrealism.

Further complicating matters is the fact that it becomes difficult if not impossible to distinguish between an objective, external setting and the subjective "reality" presented, which may be a projection of the character's desires manifested via the Machines. The reader's 
perception of the narrative is channeled and controlled by Desiderio, a male to whom Carter seems to cede an enormous amount of authority. However, he is often not ethically or cognitively reliable as a narrator. As a whole, the novel "mimics male-centred fictions in a particularly ingenious and telling way. In this text, Carter assumes the mask of maleness, using Desiderio as the only locus of narrative voice and desire - a gendering of the 'I' that the reader cannot forget for one moment" (Robinson 112). Indeed, in a novel featuring the lustful adventures of a young man who literally represents masculine desire, it is hard to forget that the author is female, especially when Carter makes a point of declaring that "it is so enormously important for women to write fiction as women" (Shaking a Leg, 42). Mandy Koolen asserts that Desiderio is an unreliable narrator because his memory is not as perfect as he claims; and "[i]n addition to his memory being faulty, readers should also question his reliability since many of his experiences with women consist of him taking advantage of power imbalances which his descriptions often try to hide or excuse" (405). By writing such a male protagonist as a feminist, Carter is simultaneously aggrandizing male lusts while condemning and critiquing them; and yet, Desiderio is young, virile, handsome, and exotic, and thus, he is a romanticized object of female desire. The desirable male protagonist reverses the romance novels' rule of writing from the female point of view (Snitow 247), while still embodying the dangerous, exotic attraction of "a sexual icon whose magic is maleness," like the male leads in romance fiction (Snitow 248). Thus, the novel not only critiques male lusts: it is an exercise in parodying, reversing, and critiquing stereotypes of female desire while also indulging in them.

Each chapter is set in a locale reminiscent of male-centered literary genres, but, in postmodern fashion, they are subversively rewritten to include graphic sexual content which these genres might typically elide. For instance, Chapter 2, "The Mansion of Midnight," recalls a 
Gothic novel: a lonely girl, Mary Anne, is trapped in a foreboding estate and needs someone to rescue her. But in Carter's version, the heroine has somnambulant sex with Desiderio and then takes her own life. Desiderio's extended sojourn on the house-boat of the River People in Chapter 3 mimics an ethnographic study, though here, the ethnographer has sex with two generations of his subject culture. Chapter 5 finds the characters in a marvelously grotesque brothel, in an evocative retelling of de Sade's style of fiction; and Chapter 7 is set in the heart of an African jungle inhabited by Centaurs who seem a sexually graphic combination of Swift's Houyhnhnms and Greek mythology. Such generic reclamations are similar to Carter's rewrites of fairy tales in The Bloody Chamber, in which she "lift[s] the covers from the body of carnal knowledge usually more modestly draped in fairy tales" (Warner 309). The chapters' strangeness contrasts with their canonical familiarity, and this contrast carries over into the conflicting insinuations about male and female desire: each chapter exposes the brutality of male sexuality, but the females of these disparate cultures are often accomplices or active participants in the erotic violence, which complicates a straightforward anti-patriarchal or anti-masculinist reading of the text.

For instance, consider Chapter 3, "The River People.” This chapter parodies an ethnography of the indigenous River People culture, but instead of learning about their culture objectively as an ethical observer might, Desiderio immerses himself fully and viscerally after he is taken in by a riverboat patriarch and becomes an honored guest of the family. The setting is confined to a small riverboat and the pseudo-Native American shantytowns along the river at which they occasionally disembark, but this mimetic space is rendered surreal, largely by the culture's bizarre notions of femininity. Desiderio observes that the River People females are so heavily painted and perform so many ritualistic gestures that they seem "like benign automata" 
about whom "it was quite possible to feel they were not fully human" (Carter 73). Although while amidst company the females seem like painted robots, Desiderio learns that when he is alone with them, they are eager to perform sexually. He has unexpected intercourse with Mama, the family's matriarch, in the boat's kitchen, interrupting her domestic duties to "give her a great deal of pleasure," as she claims (Carter 85). The mutual pleasure of this episode is juxtaposed with courtship rituals between Desiderio and Aoi, Mama's nine-year-old granddaughter. Aoi is conditioned by her culture to pleasure Desiderio, who is betrothed to her in exchange for his help in the family's trade deals. Desiderio describes Aoi is an "erotic, giggling toy" (Carter 85), and she is like a commodity given away by her family. While ethnographies typically strive to understand rather than judge the cultures they study, Desiderio's participation in this child-bride scenario violates this ethic and tests the limits of such cultural relativism.

This relativism is further strained by another barbaric, violent practice of the River People. On the night before his wedding, Desiderio learns that the River People believe that by eating the flesh of another creature, they will gain that creature's powers; and he infers from numerous clues that he is to be cannibalized at his own wedding feast so that his bride's family can acquire his literacy. In her sleep, Aoi clutches the knife that will butcher her future husband and mutters, "Tomorrow. Do it tomorrow" (Carter 92), like a first-world child might anticipate Christmas morning. Aoi's innocence — she is but "a programmed puppet with a floury face who was not the mistress of her own hands" (Carter 92) — contrasts with the shocking violence of culturally-condoned pedophilia and cannibalism. With this surprise twist near the chapter's conclusion, Carter deftly reverses the roles of victim and victimizer in the child bride scenario. As Lorna Sage points out, "Prey and predator, killer and victim, can coexist in the same person" in Carter's fiction (5). This culture that does violence to their daughters by marrying them off so 
young is eager to eat a human being if they believe they can benefit from the meal. While we condemn the River People for their cannibalism and pedophilia, we might celebrate them for their reversal of real-world female circumcision: the women perform rituals that elongate the clitoris to impossible lengths (Carter 84). Carter's characteristic ambiguity prevents a wholesale rejection of this "savage" culture, which dehumanizes its women in public while imparting them with hyperbolic female eroticism in private.

Desiderio's encounter with the River People is contrasted later with another third-world tribal culture he meets in Chapter 6, "The Coast of Africa." The characters sail across the ocean to Africa where racist, nightmarish caricatures of tribal people dwell. Carter constructs "an Africa wholly derived from European fantasy. She populates its coast with cannibal tribesmen straight out of party jokes, comic-strips, and slapstick comedy" (McHale 55). These natives reinforce characterizations of "the savage" while challenging culturally constructed notions of race, femininity, and motherhood. The patriarchal tribe has a vicious but eloquent Chief who delivers a lecture designed to terrorize the heart of the Oedipal imagination:

Gentlemen, if you rid your hearts of prejudice and examine the bases of the traditional notions of the figure of the female, you will find you have founded them all on the remote figure you thought you glimpsed, once, in your earliest childhood....Tear this notion of the mother from your hearts. Vengeful as nature herself, she loves her children only in order to devour them better and if she herself rips her own veils of self-deceit, Mother perceives in herself untold abysses of cruelty as subtle as it is refined. Not one of my callipygian soldiery but has not earned her rank by devouring alive, first gnawing limb from limb and sucking the marrow from its bones, her first-born child. (Carter 160) 
But while these Amazonian soldiers violently demythologize femininity with their cannibalistic infanticide, they simultaneously remythologize patriarchy, as they are interpellated into a militant hegemony dominated by the godlike Chief. Like the River People, this culture's gender politics can be simultaneously celebrated and condemned: the warrior-women are more powerful, prestigious, and stronger than the average male, yet they are utterly immoral and subservient to a cruel patriarch. These natives also try to cannibalize the protagonist and his friends, confronting Desiderio again with the limits of cultural relativism and goading him into his first "heroic action," gunning down the Chief (Carter 164); while the rest of the tribe scatters, Desiderio kisses Albertina like an action hero in a Kipling adventure, which is, perhaps, the very milieu of masculinist, imperialist fiction that Carter is parodying.

While Chapters 2 and 6 explore the extremes of cultural otherness, Chapters 5 and 7 interrogate how decadent literature and ancient myths glorify male gratification through violence against females. Chapter 5, "The Erotic Traveller," recalls the graphic narratives of the Marquis de Sade, which Carter analyzes extensively in The Sadeian Woman. Here, Desiderio meets the Count, an aristocratic libertine who claims to be "an artist" whose "material is the flesh" and whose "medium is destruction" (Carter 126), a "connoisseur of catastrophe" (122). In addition to Sade, the Count recalls the Surrealists: shortly after he is introduced, the Count sodomizes his valet Lafleur (q.v. de Sade's valet Latour) in a ruined church, reminiscent of Surrealists Breton and Peret's claim that "they would like to make love in a church and desecrate it" (Lewis 74). Pitchford claims, "The Count illustrates the extremes of racist and sexist violence that can result from the unopposed dominance of one set of representations" (123). The novel itself is an exercise in exposing the injustices of generic male-oriented representations, of which the Count is the extreme symbol. He is a stage villain and one of the novel's key antagonists. 
The core mythscape of this chapter is the House of Anonymity, a brothel specializing in unnatural prostitutes who do "not enter the realm of simple humanity" but are "sinister, abominable, inverted mutations, part clockwork, part vegetable, and part brute" (Carter 132). Although usually "a brothel is a fine place in which to learn misogyny" (The Sadeian Woman 30), the sex workers in the House are at best post-human, while the men who visit there are deliberately dehumanized, being forced to dress in suede costumes that make them look like giant penises: Desiderio comments that "the garb grossly emphasized our manhoods while utterly denying our humanity" (130). Sex in the House of Anonymity is an absurd, tragic-comic spectacle: giant phalluses rutting with disposable half-women, all dehumanized, all reduced to their basest forms. This surreal whorehouse is a hyperbolic dramatization of Carter's assertion that a brothel is "a closed system" and "a place of lies, of false appearances" (The Sadeian Woman, 83-84). By featuring only cyborgs, bestial mutants, and mutilated victims as its products, the House of Anonymity disturbingly entwines lust with abjection, horror, pity, and disgust. These feminized creatures transgress the boundaries that define the human and, as intended objects of lust, they embody impossible fetishes_- "all the shapes of every imaginable warped desire" (Carter 135) — which can only be fantasized, not actualized. Desiderio is repulsed by the prostitutes in the House, describing them as "malicious satires upon eroticism" (Carter 135 ) and providing another instance when the narrator's comments could self-reflexively refer to the overall text's thematic designs. Susan Sontag concedes that "images of the repulsive can also allure," and "[m]ost depictions of tormented, mutilated bodies do arouse a prurient interest" in the observer (Sontag 95). Likewise, the House of Anonymity pushes the boundary between sexual attraction and physical repulsion to its breaking point, exaggerating the dehumanizing nature of the sex trade to absurd extremes. 
Chapter 7, "Lost in Nebulous Time," is set in the village of a mythic tribe of Centaurs whose culture considers sadomasochism and misogyny sacraments of their religion. In addition to excessive tattooing and self-flagellation, the Centaurs stoically gang-rape Albertina as a way of "welcoming" her to the tribe while Desiderio is forced to watch, because in their culture the females are utterly debased and subservient to the males (Carter 179). Igor Primoratz's analysis of sexual assault asserts that all rape is cultural: "Rape is the most dramatic epitome of the inequality of men and women, and of the degradation and oppression of women by men. It is not a sporadic deviation, but a deeply entrenched social practice that both expresses and reinforces the inequality, degradation, and oppression of women" (159). The Centaur culture is the nadir of female oppression, and as if to emphasize their atavism, these people are actually part animal. Strangely, though the action itself is bestial, the rapists' attitudes are intensely cerebral: "None of them seemed to extract the least pleasure out of the act. They undertook it grimly, as though it were their duty," Desiderio notices (179).

However, despite the horrible violence inflicted upon her, Albertina is "convinced that even though every male in the village had obtained carnal knowledge of her, the beasts were still only emanations of her own desires, dredged up and objectively reified from the dark abysses of the unconscious" (186). Although some studies reveal that rape fantasies are fairly common among women, and that the "enigmatic quality of rape fantasies suggests that this domain may have important implications for advancing the understanding of women's sexuality" (Bivona and Critelli 45), Albertina's conviction that she is culpable for her rape remains difficult to interpret. In essence, she is participating in the despicable practice of blaming the victim of sexual assault; yet within the mythscape of the Desire Machines, fantasies can manifest as reality, so this may be the sole environment in which that claim is tenable. If she is responsible, then her fantasy is 
doubly taboo, both as rape and as bestiality. Since her attackers are pious Centaurs, they embody how misogyny is rooted in ancient mythology, though if they are products of her imagination, they reveal how a culture of misogyny also shapes the way women perceive themselves. But regardless of whether the Centaurs are figments of her desires or not, she exercises the ultimate power over them when the force of her rage — or her shame — channeled through the Desire Machines destroys the entire Centaur tribe in a firestorm. The maddening ambiguity of a fictional space controlled by the Desire Machines renders definitive interpretations endlessly slippery. This ambiguity, the novel suggests, is inherent in human desire, sexual fantasies, and the eroticism of the taboo.

Pitchford cites how Desiderio's complicity or lack thereof in the narrative's events is a source of controversy for critics (127-8). It is true that early in the novel, Desiderio does not consider the consequences of his role as a lustful, dominant male, but after he is gang-raped in Chapter 4 by a troop of acrobats, he experiences firsthand how it feels to be the victim of male sexual aggression. He never again takes sexual encounters lightly; in fact, he does not engage in intercourse voluntarily throughout the remainder of the book. Most tellingly, he —and the reader - are denied the narrative "climax" of the consummation of his passion for Albertina, the expected heteronormative, consensual sex that romantic novels and pornography usually guarantee. Instead he learns to empathize with the victims of sexual violence, as when he refuses to select a dehumanized prostitute (135), or when he witnesses Albertina's rape by the Centaurs and suffers vicariously, admitting, "I knew from my own experience the pain and indignity of a rape" (179). It is only in the latter half of the novel that Suleiman's claim rings true: "he clearly has an unusually sharp view of and sympathy for women's roles" ("The Fate of the Surrealist Imagination...", 114). 
Desiderio refuses to consummate his desire for Albertina in the final chapter after having sustained it for the entire novel, because to do so, they would unleash so much "eroto-energy" to power the Desire Machines that the Doctor's takeover of the world would be assured. In a sense, Dr. Hoffman is the penultimate "terrorist of the imagination" (Sadeian Woman, 21), but his mission fails because Desiderio becomes disillusioned with the Doctor and with sex in general by the end. This conclusion results in a multilayered anticlimax: Dr. Hoffman is not a colorful mad scientist but "cold, grey, still and fathomless" (Carter 204), "a totalitarian" (207) like all the other patriarchs; when Desiderio finally enters the Doctor's main laboratory and beholds the hundred men and women copulating to power the Desire Machines, he states, "I was awed and I was revolted" (214); and finally, he refuses to debase his love for Albertina just to satisfy another man's lust for power. This reluctant and even virtuous protagonist is not the same Desiderio who began this quest, and after witnessing and participating in all sorts of aberrant sex acts throughout the narrative, he bathetically abstains from the heterosexual intercourse expected of him.

The fluid interchange of the protagonist's role as aggressor, victim, voyeur, accomplice, companion, and abstainer casts doubt on the idea of "normal" sex and also implicates the reader in the process of sexual representation — for who is the ever-present voyeur throughout the narrative? Like the Desire Machines in Carter's mythscape, sex is a catalyst, a complex force that permeates the spaces of human interaction. The novel's surreal elements - the shocking juxtapositions of sex and violence, the grotesque caricatures of people, the dreamlike shifts of time and space - undermine traditional representations of sex because they generate cognition about sexual politics through alienation. Desiderio perceives that Dr. Hoffman's machines may be performing a useful service in that they transgress "the obscure and controversial borderline 
between the thinkable and the unthinkable" (Carter 22), one of several self-reflexive moments in the novel when it seems as if Dr. Hoffman could be a villainous analog of Carter herself. While pornography typically ignores "the social context in which sexual activity takes place" (Sadeian Woman, 16), Carter deliberately constructs fantastic sub-worlds in which sex acts and gender roles are dictated by the myths that structure the culture. By parodying our romantic fictions, pornographies, and the canonical literatures, the novel suggests that these genres contribute to the mythologizing of sex and gender, while the strangeness and shocking violence of the mythscape's marvelous cultures reflect how real-world notions of sexuality are also arbitrary, unjust, and subject to change.

\section{Acker's Blood and Guts in High School}

Like Carter's critical revisions of multiple literary genres, Acker's novel builds a chaotic pastiche of writings and sketches in imitation of a rather disturbed high schooler's notebook. These "notes" roughly chronicle the protagonist Janey's bizarre life, but they also contain handdrawn pornography, bits of dramatic dialogue, transcriptions of "Persian poetry," and even a faux book report. Karen Brennan describes how the pastiche style in Acker's novel "can be understood as designating a proliferation of textual and fictional surfaces, each signifying the other and thereby confounding the mental and metaphorical operations of the reader" (245), and that such "unstable textual territory" of the pastiche forms a space outside dominant discourses where feminist values might thrive (247-248). This space is the novel's mythscape, a surreal world distorted by Janey's troubled perspective and a stream-of-conscious map of her twisted mentality. Acker portrays her female protagonist's struggle for identity and love in a nightmarish world dictated by uber-powerful male characters: for example, the first paragraph of the novel 
reveals that "Janey depended on her father for everything and regarded her father as boyfriend, brother, sister, money, amusement, and father" (7). Other critics have focused in detail on the centrality of the family structure in her novel (Hawkins) and the thematic role of the novel's analysis of The Scarlet Letter (Phillips). I will place Acker's novel in dialogue with my analysis of Carter's to propose that a surreal pornographic mythscape is an ideal fictional setting for conveying the painful double bind of the troubled girl. The contradictory situations, nightmarish struggles between repulsion and desire, profane caricatures of real people (who bear little resemblance, ultimately, to the actual person being parodied), and commingling of the vulgar and the literary suggest a warped worldview which, Acker seems to argue, is the result of being an angry, rebellious, heterosexual female in a man's world.

Janey's saga begins in a South American town where she lives with her father-lover. After her tumultuous relationship with her father ends, she runs briefly with a gang and works in a stifling bakery. Then she moves to New York and lives in a slum, but she is kidnapped and sold into sex slavery. While enslaved to a Persian pimp, she writes a book report on Hawthorne's The Scarlet Letter and transcribes Arabic verses. Soon Janey develops cancer and the slave trader puts her out, so she travels to Tangier and meets the writer Jean Genet. She follows Genet and talks with him about her life, particularly an ill-fated affair with President Carter. Genet and Janey embark on a tour of Egypt, where she ultimately dies. But a simple summary of the novel's "plot" does not do justice to the experience of reading the text: it is a fascinating and maddening hodgepodge of scrawls, anecdotes, fables, poems, maps, dialogues, diary entries, and so forth, all loosely connected by the protagonist's picaresque journey. The form of the novel itself is surreal in that it progresses tumultuously through a kaleidoscope of genres and narratives. 
A key similarity to Carter's novel are Acker's parodic imitations—or appropriations—of well-established genres; by skewing and estranging these, Acker highlights the relations between patriarchal hegemony and canonical representations of sex. Dialogues between Janey and her father, or Janey and Genet, parody dramatic scripts; Janey's vulgar retelling of A Scarlet Letter parodies classic American novels. Indeed, she seems to argue that these traditional texts imbricate heterosexual scripts which dictate gender roles and establish cultural narratives for acceptable behavior, so by rewriting them, she simultaneously critiques the originals and revises their cultural scripts. Brennan considers Acker's novel in light of the feminist mission to "tease out subversive subtexts of the culture and to read 'differently.'... Such a reading/writing relies on both pastiche and parody—parody to subvert pastiche and pastiche to engender parody— vacillating hysterically between the two modes, as Acker does, to present a fiction of feminine subjectivity" (251-2). By reframing hysteria in service of feminism rather than misogyny (as its connotation in light of male doctors' outmoded diagnoses of female patients suggests), Brennan performs a rhetorical move similar to what Carter and Acker are doing with their parodies: appropriating traditionally negative ideologies for feminist purposes. Both novelists make their readers aware of the "subversive subtexts" of traditional genres by foregrounding the power dynamics of sex and the construction of gender.

Carter parodies and sometimes pays homage to traditional genres; Acker mocks and even plagiarizes patriarchal texts. After listing the various texts Acker "plagiarizes" in her fiction, Susan E. Hawkins claims, "Any text is fair game. Textual piracy becomes an act, albeit small, of feminist guerrilla warfare, for Acker's method always serves political purposes" (638). Acker is truly a postmodern pirate of fiction: she brazenly claims texts as her own and then profanes them with vulgarity and, more importantly, reinscribes them with her own brand of polemical 
feminism. Ann Bomberger explains how the novel's crude plagiarisms of canonical texts attempt to undermine an academic hierarchy which privileges males and denies its own political biases (195). Acker also contemporizes these old texts, viewing them through a vulgar, punkish lens tinged with bitterness and sarcasm. Consider this terse summary of The Scarlet Letter: "This woman [Hester Prynne] challenged the society by fucking a guy who wasn't her husband and having his kid. The society punished her by sending her to gaol, making her wear a red 'A' for adultery right on her tits, and excommunicating her" (Acker 66). The Scarlet Letter is an appropriate text for Acker to parody because it "is certainly one of the most widely taught novels in American schools" and is thus "a source of symbol and meaning" for Americans (Phillips 175); furthermore, such plagiarisms challenge the idea of art as property and thus embody in the text itself an attack on the capitalist system of late- $20^{\text {th }}$ century America (Phillips 176). Thus, her plagiarisms in and of themselves undermine the institutions of American education and capitalism, while their content challenges ideologies perpetuated by the patriarchy, which her anger and ennui caustically render passé. The mythscape is a postmodern zone in which our canonical texts are rewritten honestly, directly; in Janey's world, illusions are cast down and hypocrisies exposed.

The novel's pornographic hand-drawn sketches are convenient analogs to a prophetic peep-show featured in Carter's novel: when Desiderio travels with a carnival, he works for a peep-show operator whose violent yet marvelous images are both pornographic and disturbing, like the novel as a whole. Similarly, Acker draws stark tableaus of genitalia, partial nudes, and scenes of intercourse reinforce her book's themes and remind the reader of the voyeuristic practice of reading. The strangeness of their captions is reminiscent of Carter's blunt, sometimes riddling peep-show titles: e.g., a man's partial thighs and dripping penis are labeled "TURN MY 
EYES INSANE" (30). The sketches' seemingly random placement in the novel is itself surreal, because it is as if the reader is suddenly viewing obscene graffiti in the middle of the prose. Bomberger explains how the drawings disrupt the entrenchment of scholarly books' reliance upon the written word as the only "serious" means of representation while also, in a sense, betraying the reader: "The anonymous person reading privately in public is thus transformed into someone labeled as reading pornography. The sketches are included largely to shock, as their location [near the beginning of] the novel suggests" (196). Because the sketches are line-drawn and quite crude, they, like Carter's phony-looking peep-shows, allude to the artificiality of porn. But as reflections of Janey's radical worldview, they are also the bored doodlings in a high school student's notebook, and thus they disrupt the authority of the hypothetical teacher whose lecture is, for the moment, being ignored.

Indeed, the novel undermines male authority figures at every turn. Similar to the canonical texts she plagiarizes, Acker appropriates real people in the narrative, most significantly President Carter and Jean Genet, transporting them to the alternate universe of the fictional space so that Janey can alternately insult and adore them. These commandeered men are like caricatures in that they function more as symbols than as real people: Genet is what Janey (a thinly veiled Acker, in this episode) wants to be, a well-known but edgy writer; and (Jimmy) Carter is the penultimate male oppressor: "As a representative of the power of the state, patriarchy, and capitalism, President Carter can potentially abuse her as no other can. Their relationship highlights the fact that sex is not only not separated from politics, it can become an instrument of governmental oppression" (Bomberger 193). This President appears in the mythscape like a nightmare version of himself and behaves as such. Janey describes him as "the pillar of American society," but he is "WORN OUT by DECAying practices" (Acker 119)— 
presumably, politicking and its corrupt dealings. Although she begins her report on thenPresident Carter in the dutiful voice of a good student, her description immediately degenerates into shocking denigration: "He's HAIRY as a RAT... Because he gets whipped so much the SKIN of his ASS is DEAD and you can KNEAD it and SLICE it...Carter needs THREE HOURS OF STIMULATION TO ORGASM. This STIMULATION has to consist of PERVERTED CRUEL SADISTIC and endlessly PROLONGED EVENTS" (119-20). Far from the regal world leader he is made out to be, the American President is depicted as a sadomasochistic creature driven by depraved lusts.

With this abject, visceral description, Acker attempts to explode the illusion of presidents as clean, well-dressed, and dignified. She forces the reader to imagine this representative of the people's true form: behind the suit and tie of every man in power is an animal who shits and fucks. However, the protagonist is also implicated in this portrayal because, despite her disgust, Janey has a love affair with Carter. She admits that though she tried to avoid him, "he was screwing me so GOOD and beating me up that I knew I was going to fall in love with him" (Acker 123). Like a victim of bipolar disorder, or a woman with poor self-esteem in an abusive relationship, she oscillates wildly between loving him, lusting for him, and hating him. This behavior is not new for Janey, because it seems as if for each man she meets and loves, she harbors equally conflicting negative feelings.

The depiction of Genet is a great deal more sympathetic than this horrendous portrait of the President, but Genet's presence in the novel is still a source of pain, conflict, and abjection for Janey. She meets the French writer in Tangier, a location that itself conveys romantic connotations and is similar to Infernal Desire Machine's mythic figurations of Africa. As a city on the continent's northern border, Tangier is "an appropriable city, a sort of text upon which 
various imperialisms have inscribed themselves" (Brennan 246). Both Acker and Carter construct a surreal Africa, a fictional space that is subject to the interloper's desires: the Count's antagonistic cannibal tribe, Desiderio and Albertina's Centaur culture, and Janey's romanticized Tangier of legendary writers are all at least partly products of the characters' expectations of what "Africa" should be. She also inscribes upon Genet romanticized notions of what she hopes he can be for her, even though she knows his homosexuality precludes a sexual romance between them. Janey approaches him cautiously, like a shy fan: “I say, 'You're Monsieur Genet, aren't you?' He hesitates for a minute. He notices me but he doesn't want to. 'Who are you?' For a second I can't speak. 'I'm a writer.' He holds out his right hand to me. 'Enchanté'” (Acker 118). Yet he, too, ultimately abuses her and she debases himself for him (Acker 130). All of Janey's relationships with men share these similar characteristics: the men have power, she hates them for it, and yet she cannot seem to help but fawn over them, loving them while hating them and herself.

By the novel's end, Janey is in "gaol" in Alexandria, during which she has numerous dialogues with the oppressive men in her life. The setting of this foreign jail cell is, of course, symbolic in a few ways: she's on display "like a caged animal" (Acker 133), hemmed in by her role as a woman and rendered powerless; it is also the site of a mock-trial, a nightmare of persecution during which “an Egyptian judge who's dressed like an overdressed English barrister walks by and tells her who she is" (133). As men come and go, insulting and judging her, Janey confesses to wishing she could be a real "terrorist of the imagination" (q.v. Carter's Sadeian Woman): "when night comes, I'm going to crawl into your houses, and in your dreams where you have no power, I'll make you steal and whore. I'll turn you around" (Acker 133). She wishes she could reverse gendered roles with the men so that they will be forced to feel the 
powerlessness and shame of being the "weaker sex." Acker's book is a literary experiment in such transgression, both figuratively via the ideology it espouses and materially as re-visionary plagiarism of male-centered texts.

Blood and Guts in High School's content is likely to offend most readers, whether they are straitlaced conservatives bristling at the vulgar polemic against patriarchy, or progressive feminists appalled by Janey's abuse and self-abasement. Despite the fact that the element of shock may alienate some readers, Bomberger concludes that the novel "has significant potential for political effectiveness, ironically, in the very atmosphere it critiques most thoroughly: the classroom" (202). She gives the example of a University of Idaho controversy surrounding Acker in which some outraged students protested her visit to campus while others defended it, claiming that the value of shock is in its propensity to bring significant public attention to the issues of sexual representation and gender inequality (202-3). Even if individuals refuse to read the novel after learning of its offensive content, they may be drawn into the debates surrounding pornography, censorship, and feminism because of the attention its shock value has garnered. Acker seeks to give "voice to subjects often silenced in our culture-among them abortion, rape, incest, and the war on women's sexual desires" (Roy 73), even if these desires are ugly and offensive. Her politically incorrect representations of female desire are challenges to antiporn feminists who might seek to censor her, and liberatory exercises of the libidinous freedoms which the antifeminist forces of patriarchy have long attempted to constrain.

\section{Conclusion: Surrealist Pornography as Counternarrative}

The concept of the Girl's own story is a useful approach to explaining why radical feminists might want to have a stake in the creation of sexually graphic material. Gina 
Hausknecht describes "the Girl's own story" as a "counternarrative" to traditional "Girls' stories" of resignation to heteronormative standards of fulfillment: the former is "precisely about not fitting in, about failing, willfully or unwittingly, to fulfill normative cultural expectations," and she cites Carter and Acker as characteristic authors of such fictions (22). Because "the Girl's own story" is a conscious reversal of the assumed male subject positioning of traditional storytelling, it is necessarily disruptive (23); indeed, Carter and Acker assume our familiarity of canonical texts so they can "rewrite these stories in their own images, ransacking the texts and topoi that constitute our cultural mythology and demythologizing them, sometimes violently" (35). They both create heterogeneous mythscapes out of a patchwork of recognizable genres, whether the parodies of literary genres in Carter's case or the blatant plagiarisms of canonical literature in Acker's case. And in either case, they are keenly aware that the Girl does not figure prominently in the traditional versions (as Judith Fetterley reveals in The Resisting Reader [1978]), and her marginalization is the focus of their retellings, if sometimes only ironically or parodically.

Like the Surrealists, Carter and Acker purposely shock their readers with their outrageous pornographic fantasies. Peter Bürger writes, "Shock is aimed for as a stimulus to change one's conduct of life; it is the means to break through aesthetic immanence and to usher in (initiate) a change in the recipient's life praxis" (80). Rather than accepting the established "values" of pornography, romance literature, and canonical literature, Carter and Acker compel readers to acknowledge the violence and sexual inequality lurking beneath each genre's polished surfaces. Their mythscapes are imaginative spaces that manifest as projections of their libidinous protagonists' conscious and unconscious fantasies. The violent and strange worlds centered around these characters, sexually-saturated domains rife with allusions to literature and (pop) 
culture, tantalize us with their prurience while cognitively estranging us from our notions of sexual normality. Surrealist pornography "simultaneously beseeches and pulverizes the subject" like Julia Kristeva's concept of abjection (5), which "is perverse because it neither gives up nor assumes a prohibition, a rule, or a law; but turns them aside, misleads, corrupts; uses them, takes advantage of them, the better to deny them" (15). Likewise, these surrealist pornographic mythscapes imitate settings of recognizable genres to simultaneously critique and rebuild them for their own purposes. The novels' surreal distortions of sexual representations —nightmarish situations, parodic retellings, bizarre juxtapositions, shockingly violent diction, and so forthdeliberately complicate the erotic impulse via fear, revulsion, dark humor, and bitterness. $A b$ jectifying pornographic imagery serves to estrange the most intimate spaces of human interaction.

These novels also subvert conventions of the romance novel by deliberately overturning its clichés, suggesting that "erotica" is complicitous in the imbrication of gender normativity and unfeminist illusions about heterosexual relations: the "core of a romance novel's plot is a love story in which the heroine overcomes obstacles to identify, win the heart of, and marry the one man in the world who is right for her" (Salmon and Symons 97). Instead of the inevitable "romanticized sex" between the hero and heroine which Harlequin romances routinely depict (Snitow 261), in Carter's novel, the hero and the heroine tantalize each other throughout but in the end do not consummate their passion; instead, the hero kills the heroine. In Acker's novel, the heroine attempts relationships with a number of people who are definitely not right for her: her father, an abusive President, a homosexual male writer, etc. Pornography is just one symptom of the much larger cultural problem, the illusions about the genders and their intercourses; romance fiction and canonical literature are equally complicitous in reinforcing 
such myths. By mimicking these genres and rendering them as graphic, violent, grotesque, and shocking, Carter and Acker demonstrate that so-called women's fiction can be as obscene and offensive as the misogynistic discourses they critique while simultaneously indulging in the darkest, most taboo fantasies beyond the ken of all but the most avant-garde pornographers. 


\section{Chapter 6: Mythscapes in Post-Millennial Culture}

We create images of doom to avert doom. -Lawrence Buell.

Visions of violent, unreal spaces continue to play potent roles in twenty-first century rhetoric. Like the apocalyptic tradition, these often take the form of nightmarish futures: nuclear holocaust, global climate disaster, fundamentalist prophecy, and so forth interpellate us to engage the present through rather myopic projections of the future. Such predictions of doom are not limited to right- or left-wing propaganda, and though their agendas and ideologies may vary and often directly conflict with one another, their rhetorical approaches are similar. Mythscapes in twenty-first century religion, popular culture, politics, literature, and digital technologies awe and terrify us, relying on the primal emotion of fear to compel us to align to a particular ideology before our world transforms for the worse. This vision of transformation is often a call to action. In some cases, as with global climate change predictions, the adverse future is framed as preventable if our present course is altered; in others, as with Armageddon, our doom is regarded as inevitable: cosmic forces are aligning, so all that remains is a personal/spiritual change that must come before The End. However, while the alleged evidence for these nightmarish futures spring from discourses ranging from fundamentalist religion to scientific consensus, the visions themselves are often co-opted for political agendas outside the fields of discourse in which they were conceived, arousing skepticism of the veracity of the potential future in the first place. Thus, the mythscape's potential influence on real-world issues should be tempered by a healthy suspicion of any claims to truth emerging from the dialectic between the present material reality and a violent, invented future.

As the analysis below will reveal, contemporary apocalyptic futures tend to possess a number of important similarities. Many promote a polarization of social forces that divides the 
world into righteous, good people and wrongheaded, wicked people. Often, apocalyptic fantasies imagine "a social situation radically simplified and ennobled by the imperative of survival—a life in which good-versus-evil is all that could be said to remain of either politics or morality" (Kunkel 91). They serve as warnings of the future ranging in form from brazen threats to heuristic immersion. They can be products of partisan propaganda, titillating entertainment, or both. Most significantly, many can be linked directly to popular political movements and real effects. Demagogues from Bush to Gore to Ahmadinejad seem to recognize the rhetorical efficacy of mythscapes, and they may even fervently believe in their own mythscapes; either way, violent, imaginary spaces are having real influences upon current politics across the globe.

\section{Armageddon and Other Fundamentalist Mythscapes}

With the election of George W. Bush, a self-identified born-again Christian, and the resurgence of religious fundamentalism in post-millennial America, speculations about Armageddon or similarly drastic divine interventions are influencing American policies. Chip Berlet explains how Bush and other right-wing religious leaders are guided by "messianic militarism" and Christian Zionism, fundamentalist movements that justify brutal, imperialistic policies in the Middle East because of ancient Biblical prophecies (pars. 1, 29, and 35). Such justifications are supposedly based on prophetic visions of a future mythscape that is, for some, the ineluctable outcome of God's will: "For some Protestant evangelicals and fundamentalists the text in Revelation is read as a timetable and script for the end times, complete with a massive battle between God and Satan on the plains of Armageddon, located in Israel" (Berlet par. 10). The implications of giving credence to this fantastic cosmic battle are enormous. For one, because it is to take place in a real geographical location - the most contested, sanctified ground 
in history — this battle gives believers a crucial stake in maintaining a secure foothold in the Middle East, which can validate any imperialistic and militaristic power plays in the region. Second, if Armageddon is imminent in our near future, then far-reaching considerations for a healthy future, such as environmentalism, decreasing our dependence on fossil fuels, or the Middle East peace process, become moot. Thus, this singular mythscape serves to fulfill rightwing ideals while simultaneously undermining left-wing movements.

But American fundamentalists are, of course, not alone in their belief that God is on their side in the prophetic battles to come. Jahangir Amuzegar describes Iranian president Mahmoud Ahmadinejad as "a superstitious neo-fanatic who not only believes in the apocalypse, but also expects the physical appearance of Imam Mahdi any day soon. In his view, Iran's Islamic revolution has a distinct mission to pave the way for him to come and rescue the righteous from the wicked" (36). Ahmadinejad's conviction that the world will soon be transformed by his god gives him an unshakeable justification to be an agent of divine will; the language of this description indicates a polarization the world ("righteous" versus "wicked") as well as sweeping changes ("revolution," "pave the way", "mission") that will be necessary to hallow the ground on which his divine mythscape will be built. Such messianic convictions are similar to Christians anticipating the Rapture and the return of Christ, a concept whose popular appeal in the United States is evidenced by the Left Behind series by Tim LaHaye and Jerry Jenkins. Clearly, these contradictory versions of a divinely sanctioned battleground reveal an irresolvable conflict. In the article "Religious metaphor in the discourse of illusion: George W. Bush and Osama bin Laden," Aditi Bhatia provides a compelling analysis of how the language of both of these opposing leaders portray an illusory world divided into good versus evil, civilization versus barbarism, and light versus dark; both leaders, naturally, cast their own side as the positive and 
their enemies as the negative within these binaries. The greatest conflict of the present is bolstered by religious-based mythscapes of a projected future and an illusory present, and the zealotry with which either side believes in these prophetic myths guarantees little room for compromise or peace.

\section{"Environmental Apocalypticism"}

Lest it seem that contemporary mythscapes are the prerogative of religious fundamentalists, certain progressive discourses also utilize visions of doom in pursuit of particular political ends. The environmental movement has made effective use of mythscapes at least since Rachel Carson's 1962 book Silent Spring. Lawrence Buell praises Carson for her influence on "environmental apocalypticism" and the resulting surge of vocal environ-mentalists during the 1960s, asserting that "the role of the imagination is central to the project" of environmental apocalypticism because "the imagination is being used to anticipate and, if possible, forestall actual apocalypse" (295). The spatially oriented discourse of environmentalism seems to transfer well to describing mythscapes of a despoiled world in the future, as exemplified by current investigations into global climate change. In contrast to the battlegrounds of Armageddon, the violence in such settings is inflicted primarily upon the natural world. While there is indeed a major difference between teleologies spawned from subjective interpretations of holy texts and those projected from objective scientific evidence, their rhetorical approaches to imagined futures share some remarkable similarities. Consider how the typical future scenarios of global climate change rhetoric recall Biblical language of global disaster: climatologists' "forecast for the rest of the planet approximates the apocalypse: famine, drought, hurricanes, floods, mass extinctions — the list goes on" (Shapiro par. 4). Jeremy Lovell 
notices interesting parallels between religious faith and belief in global climate change, which he claims has been described by popular media in the misleading "language of religious fervor" (par. 1):

People who say human-induced climate change is a fact that demands urgent action are described as "believers" or "climate evangelists," while those who reject the concept are "deniers," "skeptics" or "atheists." Those in the middle who say they are unconvinced either way are "agnostics."...The contagious, semireligious linguistic brew is further fueled by climate alarmists, from environmentalists to politicians, warning of looming apocalyptic disasters or seeing themselves pitted in an Armageddon-like struggle between the forces of good and evil. (pars. 2 and 5).

Though the evidence for the global-warming apocalypse is grounded in science instead of religious prophecy, the message disseminated by many of its politically minded advocates remains the same: unless we change our sinful ways, we face untold wrath from forces much greater than ourselves.

By co-opting the language of religion in their discourse about a doomed world, proponents of anthropogenic climate change run the risk of having their prophecies dismissed as readily as secular humanists might dismiss Revelations. Christina R. Foust and William O'Shannon Murphy make a similar claim about "apocalyptic despair" in global warming discourse, which "invites naysayers to discredit scientists as false prophets and label environmentalists as alarmists" (161-2). Perhaps the most egregious example of a global climate change scenario as an imminent threat is the film The Day After Tomorrow (2004). This unsettling narrative of global warming depicts tidal waves and a new Ice Age, but it could be 
argued that the urgency of its message is undercut every two days as our world remains largely unchanged. We are so jaded by failed prophecies of the end of the world that we react to such mythscapes with reasonable suspicion. Evidence is not enough in "an Age of Fantasy," as Stephen Duncombe explains: a "compelling narrative" is just as important (19), and at times the narratives of global warming seem too similar to the clichéd dooms promised by religious fanatics. Recognizing this counterproductive parallel, the cause of global climatologists could benefit from consciously eschewing the teleology of the global warming future mythscape and devote their energies to curtailing the existing problems of waste and consumption that could clearly lead to environmental problems down the road (q.v. Foust and Murphy 164).

Construction of a global warming mythscape seems increasingly untenable when contrasted with similar messages from non-scientific sources, because skeptics are used to dismissing such predictions, and fundamentalists already tend to distrust science as contradictory to their religious beliefs. Mythscapes, it seems, are not as cogent in all discourses, and the speculative, marvelous design of these spaces may not be an appropriate fit alongside scientific observations.

\section{Virtual Worlds as Mythscapes}

Some contemporary mythscapes are designed for entertainment and heuristic immersion in violent, unreal spaces; these are less likely to have an overt political motive, though they can be analyzed for rhetorical content. Digital imaging and a global communication network promise a rich future for the creation of virtual mythscapes. Rather than individual experiences of static texts, as with literary mythscapes, virtual online worlds involve dynamic texts that are constructed collectively. World of Warcraft, the definitive massively multiplayer online roleplaying game (MMORPG) since its release in 2004, is set in a violent fantasy world where 
players can battle computer-driven monsters and wage war against other players. The game pits the Alliance (the "good" races, Elves, Humans, Dwarves, etc) against the Horde (the "bad" races, Orcs, Trolls, Undead, etc), and new players must choose one side or the other for their characters. There is no chance to defect or to remain neutral in this war, though fighting other players is limited to arenas where the opposing armies battle, and such fights are not the entirety of the possible gameplay. Marlin C. Bates, IV argues that the creation of identity in MMORPGs "expands the definition of "place" by transferring the concept of the parochial community from a real-world environment to a virtual one (103), though the community is no less "real" for being immaterial (114). By participating in such a mythscape, players are expected to devote large amounts of time engaged in a virtual world constantly at war and divided by essentialized fantasy races, while exploring new spaces for social interaction with other players from around the real world. Immersion in this fantasy world does not require belief so much as suspension of disbelief; while it may lack in real-world relevance compared to these other contemporary mythscapes, it suggests a projected future of its own, wherein online communities of absurd, marvelous identities are forged, perhaps becoming viable substitutes for mundane, face-to-face interaction and competition.

The creation of 3D virtual worlds for single-player (non-MMORPG) games also provides a compelling venue for immersion in increasingly "realistic" mythscapes. The 2008 video game Fallout 3 is particularly relevant to an analysis of apocalyptic futures, as it is set in the Washington, D.C. area after a nuclear holocaust. Exploring the game world is a harrowing, uncanny experience. Familiar D.C. landmarks, like the Lincoln Memorial, the Mall, the Washington Monument, and so forth are clearly recognizable but ravaged by nuclear destruction. The game designers explain, "The U.S. Capital is thick with imagery and symbolism which is 
only amplified against an apocalyptic backdrop" ("Notes on Pulling the Sky Down," par. 2). They also propose an interesting contrast between world-building and story in video games as opposed to traditional narrative: "Much of our storytelling as level designers, however, is told with the voice of the world...A lonely grave, a heap of human gore, or a long-abandoned outpost convey atmosphere and meaning without a single written word. These small stories all contribute to both the truth of setting and the unique narrative of each player's experience playing Fallout 3" ("Notes on Pulling the Sky Down," par. 14, italics added). Rather than warning us about the potential threat of nuclear war, this game invites us to experience its aftermath in a real and dear location, a rhetorical move which implicitly alludes to the fragility of American civilization while making a powerful argument for nuclear disarmament.

Equally significant as the choice of setting are the moral choices that the game offers the player. Unlike linear video games, Fallout 3 is very open-ended; the game world is large and can be explored according to the player's whim. One can decide to play a virtuous hero on a mission to help the struggling survivors, or a malicious rogue taking full advantage of the lawless, desperate setting. Early in the game, for example, the player discovers the town of Megaton, so named because an undetonated nuclear bomb sits in a crater in the center of the community. Some villagers even worship the bomb, though it leaks radiation and continues to endanger the locals. But one man in town approaches the player with an offer: if a certain part is affixed to the bomb, it can be detonated from afar with a device in the man's possession. How the player responds to this heinous offer can have a profound effect on the player character's moral stance and his or her choice of a home base in the game world. Virtuous players may balk at the offer and turn in the man, or fight him then and there. But the game allows the player to take a more sinister path that culminates in the detonation of the bomb and the utter destruction of the entire 
town. This decision reflects the type of choices that players can make throughout the entire game, up to and including the final scene. The game's epilogue recounts the history of the protagonist, who may be lauded as a saint if he or she has taken a number of crucial small steps to begin to undo the ravages of nuclear war, or reviled as a villain if the tempting but ultimately less rewarding path of selfishness is chosen. Such subjective immersion creates the illusion of a personalized, participatory experience beyond the ken of film or literary narratives.

The increasing legitimization of immersive video environments will imbue these spaces with much potential for identity, expression, and argument. While describing his enjoyment of the game Grand Theft Auto: San Andreas, in which the player takes on the role of a thug immersed in a world of "gangsta" violence, Duncombe writes: "Perhaps Freud was right: we are libidinal animals after all and GTA/SA is a virtual arena in which to express eternal desires for sex and death we might otherwise play out dangerously on terra firma" (Duncombe 54). Roleplaying the subject position in violent mythscapes rendered with 3D imaging provides a release for aggression and negative wish-fulfillment in ways that reading or watching a narrative cannot quite replicate. Marie-Laure Ryan agrees that taking on an identity in a virtual world can be a "liberating expression of culturally repressed desires" (61); and in regards to the space itself, she writes, "the creation and exploration of imaginary worlds can be an instrument of self-discovery" (63), resulting in "an experience that blends the aesthetic with the mystical and the metaphysical" (65). Creating an identity in these mythscapes explores issues of self and other, and immersing oneself in these worlds allows for extended, detailed engagement with any arguments inherent in the setting, as with the nuclear-ravaged Washington, D.C. of Fallout 3. The possibilities for the proliferation of such mythscapes are indeed vast. For example, "Virtual Hell" is still in its rudimentary stages, but believers' hearts may quail when a fully-developed, 
3D tour of the horrors of Hell becomes readily available. Likewise, interactive models of how global climate change could affect the world may be more convincing than overtly-political pundits' claims. Providing avenues for individuals to participate in the experience of the mythscape (q.v. Duncombe 72-76), rather than browbeating them with threats of a doomed world, could prove a more effective and personalized form of setting-as-argument.

\section{Threat vs. Immersion: A Comment on Rationality and Efficacy}

In many cases, the propagation of a mythscape in the service of a particular political agenda amounts to ideological bullying: we are made to fear a possible future, and the threat of violence cows us into behaving ourselves according to that agenda. Much doomsday rhetoric about global warming in popular media, for instance, relies upon the same threat-response impulse that has characterized traditional fire-and-brimstone warnings of Hell, because the sense of certainty, the urgency, and the desire to garner followers are motives that are shared by these divergent ideologies. This is not a commentary on the truthfulness of either ideology so much as a critique of the rhetorical approach of the mythscape as threat, because our suspicion of one type of doom makes it easier to be dismissive of all such visions. Foust and Murphy contend that global warming rhetoric which is characterized as "tragic" and "Fated" tends to cause despair and resignation instead of productive action; furthermore, "such a discourse polarizes readers, who are forced to choose sides because they are not given more nuanced options for addressing the issue" (161-2). They suggest that reframing the narrative of global warming in a way that "promote[s] human agency" is less likely to be dismissed and more likely to encourage positive action (163). The methods by which narratives of future doom are portrayed, then, can have a large impact on whether a mythscape has the potential to elicit proactive behavior. 
Threats of horrors to come can be excessively drastic and polarizing, whereas an immersive narrative might be a more effective, engaging, and rational approach. Literary and virtual mythscapes have an advantage over punditry in this regard because immersion is their strong suit. Fallout 3, Cormac McCarthy's The Road (2006), or even LaHaye and Jenkins's Left Behind series are immersive versions of the potential "realities" of life after apocalypse that invite engagement with that speculative world rather than knee-jerk reactions to possible dooms. While immersed in such a fictional space, the ideological underpinnings become an ever-present feature of the setting itself, while the suspense of the plot, character growth and relationships, and other narratival traits attempt to build connections to the universal human condition as well as our own lives. Immersion encourages more complex responses to our potentially violent fates, and a lasting engagement with the mythscape can elicit more personal reflections on the present. Creators of contemporary mythscapes should recognize the limitations of coercion through fear and attempt a more nuanced approach that harnesses the rational, thoughtful, and credulous impulses of their intended audience, who may turn from skeptics into advocates if the mythscape is believable enough. 


\section{Works Cited}

Abbey, Edward. The Journey Home: Some Words in Defense of the American West. New York:

E. P. Dutton, 1977.

Abbott, Carl. Frontiers Past and Future: Science Fiction and the American West. Lawrence: UP of Kansas, 2006.

Acker, Kathy. Blood and Guts in High School. New York: Grove, 1978.

Aguiar, Marian. "Making Modernity: Inside the Technological Space of the Railway." Cultural Critique 68 (Winter 2008): 66-85. EBSCO. 11 November 2009.

Alighieri, Dante. The Divine Comedy. Trans. by John Ciardi. New York: W. W. Norton, 1970.

Amuzegar, Jahangir. "The Ahmadinejad Era: Preparing for the Apocalypse.” Journal of International Affairs 60.2 (Spring/Summer 2007): 35-53. EBSCO. Web. 15 October 2010.

Anzaldúa, Gloria. "Borderlands/La Frontera." Literary Theory: An Anthology. $2^{\text {nd }}$ edition. Ed. by Julie Rivkin and Michael Ryan. Malden: Blackwell, 2004. 1017-1030.

Attlesey, Sam. "Bush tells Texans that he's taking his home state's values to the White House." Dallas Morning News, The (TX) (17 Jan 2001): n. p. EBSCO. Web. 3 Aug. 2010.

Avatar. Dir. James Cameron. Perf. Sam Worthington, Zoe Saldana, and Sigourney Weaver. Twentieth Century Fox, 2009. Film.

Bachelard, Gaston. The Poetics of Space. Trans. by Maria Jolas. Boston: Beacon P, 1994. Bakhtin, Mikhail Mikhailovich. The Dialogic Imagination: Four Essays. Ed. by Michael Holquist. Trans. by Caryl Emerson and Michael Holquist. Austin: U of Texas P, 2006.

Barr, Marleen S. Feminist Fabulation: Space/Postmodern Fiction. Iowa City: U of Iowa P, 1992. Barthes, Roland. Mythologies. Trans. by Annette Lavers. New York: Hill and Wang, 1972. 
Bates, Marlin C., IV. "Persistent Rhetoric for Persistent Worlds: The Mutability of the Self in Massively Multiplayer Online Role-Playing Games.” Quarterly Review of Film and Video 26 (2009): 102-117. EBSCO. Web. 15 October 2010.

Bateson, Gregory. Steps to an Ecology of Mind. Chicago: U of Chicago P, 2000.

Baudrillard, Jean. Simulacra and Simulation. Trans. by Sheila Faria Glaser. Ann Arbor: U of Michigan P, 1994.

Baym, Nina, et al, eds. The Norton Anthology of American Literature Vol. A. $7^{\text {th }}$ ed. New York: Norton, 2007.

Beck, John. "Without Form and Void: The American Desert as Trope and Terrain." Nepantla: Views from the South 2.1 (2001): 63-83. EBSCO. 11 November 2009.

Berlet, Chip. "Pastor Hagee’s Armageddon Politics.” Huffington Post 22 May 2008: n.p. Web. 10 October 2010. <http://www.huffingtonpost.com/chip-berlet/pastor-hageesarmageddon_b_103161.html>.

Bhatia, Aditi. "Religious metaphor in the discourse of illusion: George W. Bush and Osama bin Laden.” World Englishes 26.4 (2007): 507-524. EBSCO. Web. 15 October 2010.

Birns, Nicholas. "From Cacotopias to Railroads: Rebellion and the Shaping of the Normal in the Bas-Las Universe.” Extrapolation 50.2 (Summer 2009): 200-211.

Bishop, K. J. The Etched City. New York: Bantam Spectra, 2003.

---. "Whose Words you Wear." The New Weird. Ed. by Ann and Jeff Vandermeer. San Francisco: Tachyon Publications, 2008. 345-348.

Bivona, Jenny, and Joseph Critelli. “The Nature of Women's Rape Fantasies: An Analysis of Prevalence, Frequency, and Contents.” Journal of Sex Research 46.1 (2009): 33-45. EBSCO. Web. 17 March 2010. 
Boggs, Carl and Tom Pollard. "Hollywood and the Spectacle of Terrorism." New Political Science 28.3 (September 2006): 335-351. EBSCO. Web. 24 January 2010.

Bomberger, Ann. "The Efficacy of Shock for Feminist Politics: Kathy Acker's Blood and Guts in High School and Donald Barthelme's Snow White." Gender Reconstructions: Pornography and Perversions in Literature and Culture. Ed. by Cindy L. Carlson, Robert L. Mazzola, and Susan M. Bernardo. Burlin: Ashgate, Aldershot, Hants, 2002. 189-204. ILLiad. Web. 3 March 2010.

Brennan, Karen. “The Geography of Enunciation: Hysterical Pastiche in Kathy Acker's Fiction.” boundary 221.2 (1994): 243-268. EBSCO. Web. 26 Feb 2010.

Buehrer, David. "The Postmodern and the Post-apocalyptic in Garcia Marquez's Love in the Time of Cholera." Critique 32.1 (Fall 1990): 13-26. Retrieved from EBSCOHost.

Buell, Lawrence. The Environmental Imagination: Thoreau, Nature Writing, and the Formation of American Culture. Cambridge: Harvard UP, 1995.

Bürger, Peter. Theory of the Avant-Garde: Theory and History of Literature, Vol. 4. Trans. by Michael Shaw. Minneapolis: U of Minnesota P, 2004.

Burgess, Anthony. A Clockwork Orange. New York: W. W. Norton, 1986.

Burling, William J. "Periodizing the Postmodern: China Miéville's Perdido Street Station and the Dynamics of Radical Fantasy.” Extrapolation 50.2 (Summer 2009): 326-344.

Busby, Mark. "Sam Shepard and Frontier Gothic." Frontier Gothic: Terror and Wonder at the Frontier in American Literature. Ed. by David Mogen, Scott P. Sanders, and Joanne B. Karpinski. Cranbury: Associated UPs, 1993. 84-93.

Butler, Judith. "The Value of Being Disturbed.” Theory \& Event 4.1 (2000): n.p. http://muse.jhu.edu/journals/theory_and_event/v004/4.1butler.html. 
Butler, Octavia E. Parable of The Sower. New York: Warner, 1993.

Campbell, Bill. “Re: Sunshine.” Message to Jonathan Harvey. 23 Feb 2010. E-mail.

---. Sunshine Patriots. Tucson: Hats Off, 2004.

---. "The Cyborgs are Coming." Tome of the Unknown Writer. 15 Feb 2009. Web. 6 Feb 2010. $<\mathrm{http}$ //bootynovelbill.blogspot.com/2009/02/cyborgs-are-coming.html>

Campbell, Joseph. Myths to Live By. New York: Penguin/Arkana, 1993 [1972].

Carson, Rachel. Silent Spring. 40 ${ }^{\text {th }}$ Anniversary Ed. New York: Houton-Mifflin, 2002.

Carter, Angela. Heroes and Villains. New York: Penguin, 1969.

---. The Infernal Desire Machines of Doctor Hoffman. New York: Penguin, 1972.

---. The Sadeian Woman. New York: Penguin, 1979.

---. Shaking a Leg: Collected Writings. New York: Penguin, 1997.

Cederstrom, Lorelei. “'Inner Space' Landscape: Doris Lessing's Memoirs of a Survivor.” Mosaic 13 (1980): 115-132. Retrieved from ILLiad.

Cixous, Hélène. "The Laugh of the Medusa." Trans. by Keith Cohen and Paula Cohen. Signs: Journal of Women in Culture and Society 1.4 (Summer 1976): 875-893. Retrieved from JSTOR.

Corkin, Stanley. "Cowboys and Free Markets: Post-World War II Westerns and U.S. Hegemony." Cinema Journal 39.3 (Spring 2000): 66-91. Project MUSE. 11 November 2009.

Corn, David. "Bush's other lies.” The Nation, 13 October 2003: 11-16. EBSCO. Web. 24 January 2010.

Cornwell, Jane. "The Post-Nuclear Evangelist." The Australian 24 November 2007. Newspaper Source. Retrieved from EBSCOHost. 
Daly, Mary. Pure Lust: Elemental Feminist Philosophy. Boston: Beacon, 1984.

Davies, Alice. "New Weird 101.” SFRA Review 291 (Winter 2010): 6-9.

de Certeau, Michel. From The Practice of Everyday Life. Trans. by Steven Rendall. Literary

Theory: An Anthology. $2^{\text {nd }}$ edition. Ed. by Julie Rivkin and Michael Ryan. Malden:

Blackwell, 2004. 1247-1257.

Decker, Mark. "Politicized Dystopia and Biomedical Imaginaries: The Case of 'The Machine

Stops." New Boundaries in Political Science Fiction. Ed. by Donald M. Hassler and

Clyde Wilcox. Columbia: U of South Carolina P, 2008. 53-64.

Deleuze, Gilles and Felix Guattari. Anti-Oedipus: Capitalism and Schizophrenia. Trans. Hurley, Seem, and Lane. Minneapolis: U of Minnesota P, 2003.

Dennison, Matthew. "Worshipping false gods." The Times (United Kingdom) 22 September 2007. Newspaper Source. Retrieved from EBSCOHost.

Disch, Thomas. The Dreams our Stuff is Made Of: How Science Fiction Conquered the World. New York: Simon and Schuster, 1998.

Dowling, David. Fictions of Nuclear Disaster. Iowa City: U of Iowa P, 1987.

Draine, Betsy. "Changing Frames: Doris Lessing's Memoirs of a Survivor." Studies in the Novel 11 (1979): 51-62. Retrieved from EBSCOHost.

Duncombe, Stephen. Dream: Re-Imagining Progressive Politics in an Age of Fantasy. New York: New P, 2007.

Eaton, A. W. “A Sensible Antiporn Feminism.” Ethics 117 (July 2007): 674-715. EBSCO. Web. 26 August 2010.

Fallout 3. Rockville: Bethesda Softworks, 2008. DVD-ROM.

Fetterley, Judith. The Resisting Reader: A Feminist Approach to American Fiction. 
Bloomington: Indiana UP, 1978.

Foust, Christina R. and William O’Shannon Murphy. "Revealing and Reframing Apocalyptic Tragedy in Global Warming Discourse.” Environmental Communication 3.2 (July 2009): 151-167. EBSCO. Web. 15 October 2010.

Franklin, H. Bruce. Vietnam and Other American Fantasies. Amherst: U of Massachusetts P, 2000.

Freedman, Carl. Critical Theory and Science Fiction. Hanover: Wesleyan UP, 2000.

---. "To the Perdido Street Station: the representation of revolution in China Miéville's Iron Council.” Extrapolation 46.2 (Summer 2005): 235-249. EBSCOHost. Web. 13 March 2008.

Gare, Arran. "The Politics of Recognition versus the Politics of Hatred." Democracy \& Nature 8.2 (2002): 261-280. EBSCO. Web. 24 January 2010.

Gearhart, Sally Miller. The Wanderground: Stories of the Hill Women. Boston: Alyson, 1984.

Gilman, Charlotte Perkins. "The Yellow Wallpaper.” The Portable American Realism Reader. Ed. by James Nagel and Tom Quirk. New York: Penguin, 1997. 254-269.

Gubar, Susan. "Representing Pornography: Feminism, Criticism, and Depictions of Female Violation.” Critical Inquiry 13.4 (Summer 1987): 712-741. JSTOR. Web. 5 March 2010.

Haldeman, Joe. The Forever War. New York: St. Martin's, 2009 [1974].

Hand, Elizabeth. Winterlong. New York: Harper-Collins, 1997.

Hannity, Sean and Alan Colmes. "George Bush Addresses Australian Parliament." Hannity \& Colmes (FOX News) (22 Oct 2003): Newspaper Source. EBSCO. Web. 3 Aug. 2010. Harari, Yuval Noah. "Martial Illusions: War and Disillusionment in Twentieth-Century and Renaissance Military Memoirs.” Journal of Military History 69 (January 2005): 43-72. 
Haraway, Donna. "A Cyborg Manifesto: Science, Technology, and Socialist-Feminism in the Late Twentieth Century." Simians, Cyborgs and Women: The Reinvention of Nature. New York: Routledge, 1991. 149-181. Retrieved 11-25-2008 from $<$ http://www.stanford.edu/dept/HPS/Haraway/CyborgManifesto.html $>$.

---.Modest_Witness@Second_Millennium.FemaleMan ${ }_{-}$Meets_OncoMouse ${ }^{T M}$ :Feminism and Technoscience. New York: Routledge, 1997.

Harris, Paul. "Dubya rides in and it's high noon for IRA and Iraq." Daily Mail (London) 8 April 2003: 13. LexisNexis. Web. 30 Sept. 2009.

Harvey, David. Spaces of Global Capitalism: Towards a Theory of Uneven Geographical Development. New York: Verso, 2006.

Hawkins, Susan E. "All in the Family: Kathy Acker's Blood and Guts in High School." Contemporary Literature 45.4 (Winter 2004): 637-658. JSTOR. Web. 26 Feb 2010. Hausknecht, Gina. "Self-Possession, Dolls, Beatlemania, Loss: Telling the Girl's Own Story." The Girl: Constructions of the Girl in Contemporary Fiction by Women. Ed. by Ruth O. Saxton. New York: St. Martin's P, 1998.

Herr, Michael. Dispatches. New York: Vintage, 1991.

Hoberman, J. "Vietnam: The Remake.” Remaking History. Ed. by Barbara Kruger and Phil Mariani. New York: New P, 1998. 174-196.

Hutcheon, Linda. The Politics of Postmodernism. New York: Routledge, 1989.

Jackson, Rosemary. Fantasy: The Literature of Subversion. New York: Routledge, 1981.

Jones, Gwyneth. "Kairos (what the apocalypse means to me)." Updated November 1997. Retrieved October 6, 2008. <http://homepage.ntlworld.com/gwynethann/Kairos.htm> Karpinski, Eva. "Signifying Passion: Angela Carter's Heroes and Villains as a Dystopian 
Romance." Utopian Studies 11.2 (2000): 137-151. Retrieved from EBSCOHost.

Keller, Alexandra. "Historical Discourse and American Identity in Westerns since the Reagan Era." Hollywood's West: The American Frontier in Film, Television, and History. Ed. by Peter C. Rollins and John E. O’Connor. Lexington: UP of Kentucky, 2005. 239-260. Kershaw, Baz. The Politics of Performance: Radical Theatre as Cultural Intervention. New York: Routledge, 1992.

Kimmel, Michael S., ed. The Gender of Desire: Essays on Male Sexuality. New York: State University of New York P, 2005.

Kimmel, Michael S. and Rebecca F. Plante. "The Gender of Desire: The Sexual Fantasies of Women and Men." The Gender of Desire: Essays on Male Sexuality. Ed. by Michael S. Kimmel. New York: State University of New York P, 2005.

Kolodny, Annette. The Lay of the Land: Metaphor as Experience and History in American Life and Letters. Chapel Hill: U of North Carolina P, 1984.

Koolen, Mandy. "Undesirable Desires: Sexuality as Subjectivity in Angela Carter's The Infernal Desire Machines of Doctor Hoffman." Women's Studies 36.6 (2007): 399-416.

Kristeva, Julia. Powers of Horror: An Essay on Abjection. Trans. by Leon S. Roudiez. New York: Columbia UP, 1982.

Kunkel, Benjamin. "Dystopia and the End of Politics." Dissent Fall 2008: 89-98. EBSCO. Web. 15 October 2010.

Lacey, Lauren J. "Octavia E. Butler on Coping with Power in Parable of the Sower, Parable of the Talents, and Fledgling." Critique 49.4 (Summer 2008): 379-394.

LaHaye, Tim, and Jerry B. Jenkins. Glorious Appearing: The End of Days. Wheaton: Tyndale House, 2004. 
Lakoff, George. "Metaphor and War: The Metaphor System Used to Justify War in the Gulf (Part 1 of 2)". Viet Nam Generation Journal and Newsletter (November 1991): n.p. Web. $<$ http://www2.iath.virginia.edu/sixties/HTML_docs/Texts/Scholarly/Lakoff_Gulf_Metap hor_1.html>.

Langille, Chris. "Political and moral myths in American foreign policy: the neoconservative question." International Journal of Contemporary Iraqi Studies 2.3 (2008): 321-336. EBSCO. Web. 24 January 2010.

Lefebvre, Henri. The Production of Space. Trans. by Donald Nicholson-Smith. Malden: Blackwell, 1991.

Le Guin, Ursula K. The Word for World is Forest. New York: Berkley, 1976.

Lem, Stanislaw. Solaris. Trans. by Joanna Kilmartin and Steve Cox. New York: Berkley, 1970.

Lessing, Doris. The Memoirs of a Survivor. New York: Random House, 1988.

Lewis, Helena. The Politics of Surrealism. New York: Paragon House, 1988.

Limerick, Patricia Nelson. Desert Passages: Encounters with the American Deserts. Albuquerque: U of New Mexico, 1985.

Lovecraft, H. P. "The Horror at Red Hook.” The Transition of H. P. Lovecraft: The Road to Madness. New York: Random House, 1996.

Lovell, Jeremy. "Language of Religious Fervor Inflames Climate Change Debate." New York Times. New York Times, 19 March 2010. Web. 3 May 2010. $<$ http://www.nytimes.com/cwire/2010/03/19/19climatewire-language-of-religious-fervorinflames-climat-42978.html>.

Luckhurst, Roger. Science Fiction. Malden: Polity, 2005.

Lutwack, Leonard. The Role of Place in Literature. Syracuse: Syracuse UP, 1984. 
Malcolm-Clarke, Darja. “Tracking Phantoms.” The New Weird. Ed. by Ann and Jeff

Vandermeer. San Francisco: Tachyon Publications, 2008. 337-343.

Marx, Leo. The Machine in the Garden: Technology and the Pastoral Ideal in America. New York: Oxford UP, 1964.

McCarthy, Cormac. The Road. New York: Vintage, 2006.

McDonough, Kathleen A. "Wee Willie Winkie Goes West: The Influence of the British Empire Genre on Ford's Cavalry Trilogy." Hollywood's West: The American Frontier in Film, Television, and History. Ed. by Peter C. Rollins and John E. O'Connor. Lexington: UP of Kentucky, 2005. 99-114.

McHale, Brian. Postmodernist Fiction. New York: Routledge, 1987.

Mendlesohn, Farah. Rhetorics of Fantasy. Middletown: Wesleyan UP, 2008.

Miéville, China. Iron Council. New York: Ballantine Books, 2004.

Mikkonen, Kai. “The Hoffman(n) Effect and the Sleeping Prince: Fairy Tales in Angela Carter's The Infernal Desire Machines of Doctor Hoffman." Marvels and Tales 12.1 (1998): 155174.

Miller, Abraham H. "The Los Angeles Riots: A Study in Crisis Paralysis." Journal of Contingencies and Crisis Management 9.4 (December 2001): 189-199. Retrieved from EBSCOHost.

Miller, Jim. "Post-Apocalyptic Hoping: Octavia Butler’s Dystopian/Utopian Vision." ScienceFiction Studies 25 (1998): 336-359. Retrieved from ILLiad.

Mydans, Seth. "The Police Verdict: Los Angeles Policemen Acquitted in Taped Beating." The New York Times 30 April 1992: A1. Retrieved from LexisNexis.

Neuharth, Al. "Memorial Day words to heed: 'War is hell'." USA Today 25 May 2007: 21 a. 
Academic Search Complete. EBSCO. Web. 24 Jan. 2010.

"Notes on Pulling the Sky Down: The Level Design of Fallout 3." Fallout: Welcome to the Official Site. 2010. Web. 30 October 2010.

$<$ http://fallout.bethsoft.com/eng/vault/diaries_diary6-10.14.08.html>.

Orwell, George. Nineteen Eighty-Four. New York: Penguin, 1984.

O’Brien, Tim. The Things They Carried. New York: Mariner, 2009.

O’Dea, Gregory. "Prophetic History and Textuality in Mary Shelley's The Last Man." Papers on Language and Literature 28.3 (Summer 1992): 283-304. EBSCO. Web. 8 June 2010.

O'Shaughnessy, Nicholas. "Weapons of Mass Seduction: Propaganda, Media, and the Iraq War." Journal of Political Marketing 3.4 (2004): 79-104. EBSCO via ILLiad. Web. 25 January 2010.

Page, Benedicte. "Fighting the new Dark Ages." Bookseller (17 Aug. 2007): 18-19. EBSCO.

Web.

Passmore, John. "Torching of Los Angeles; Riot killings after jury clears white police of beating." The Evening Standard (London) 30 April 1992: 1. LexisNexis. Web.

Penley, Constance. "Crackers and Whackers: The White Trashing of Porn.” Porn Studies. Ed. by Linda Williams. Durham: Duke UP, 2004. 309-331.

Perlstein, Rick. Nixonland: The Rise of a President and the Fracturing of America. New York: Scribner, 2008.

Peters, Michael, and Colin Lankshear. "Postmodern Counternarratives." Counternarratives: Cultural Studies and Critical Pedagogies in Postmodern Spaces. Ed. by Henry A Giroux, Colin Lankshear, Peter McLaren, and Michael Peters. New York: Routledge, 1996. 1-39. Phillips, Jerry. "The Intuition of the Future: Utopia and Catastrophe in Octavia Butler's Parable 
of the Sower." Novel: A Forum on Fiction 35.2/3 (Spring/Summer 2002): 299-311.

Retrieved from EBSCOHost.

Phillips, Rod. "Purloined Letters: The Scarlet Letter in Kathy Acker's Blood and Guts in High School." Critique 35.3 (Spring 1994): 173-180. EBSCO. Web. 26 Feb 2010.

Pitchford, Nicola. Tactical Readings: Feminist Postmodernism in the Novels of Kathy Acker and Angela Carter. Lewisburg: Bucknell UP, 2002.

Pohl, Frederik. "The Politics of Prophecy." Political Science Fiction. Ed. by Donald M. Hassler and Clyde Wilcox. Columbia: U of South Carolina P, 1997. 7-17.

Primoratz, Igor. Ethics and Sex. New York: Routledge, 1999.

Robinson, Douglas. American Apocalypses: The Image of the End of the World in American Literature. Baltimore: Johns Hopkins UP, 1985.

Robinson, Sally. "The Anti-Hero as Oedipus: Gender and the Postmodern Narrative in The Infernal Desire Machines of Doctor Hoffman." Angela Carter. Ed. by Alison Easton. New York: St. Martin’s, 2000. 107-126. ILLiad. Web. 23 Jan 2009.

Rome, Adam. “'Give Earth a Chance': The Environmental Movement and the Sixties.” Journal of American History 90.2 (September 2003): 525-554. Retrieved from EBSCOHost.

Rosenfeld, Aaron S. "Re-membering the Future: Doris Lessing's 'Experiment in Autobiography." Critical Survey 17.1 (2005): 40-55. Retrieved from EBSCOHost.

Roy, Jyoti. "Blood and Guts in High School: Kathy Acker, 1984.” Bitch 38 (Winter 2008): 72-

73. EBSCO. Web. 26 August 2010.

Ryan, Marie-Laure. Narrative as Virtual Reality: Immersion and Interactivity in Literature and Electronic Media. Baltimore: Johns Hopkins UP, 2001.

Ryan, Maureen. The Other Side of Grief: The Home Front and the Aftermath in American 
Narratives of the Vietnam War. Amherst: U of Massachusetts P, 2008.

Sage, Lorna, ed. Flesh and The Mirror: Essays on the Art of Angela Carter. London: Virago P, 1994.

Salmon, Catherine, and Don Symons. "Slash Fiction and Human Mating Psychology." Journal of Sex Research 41.1 (February 2004): 94-100. EBSCO. Web. 30 March 2010.

Sargent, Pamela. Interview with Jill Engel-Cox. Pamela Sargent. December 2000-April 2001. Web. 4 November 2010. $<$ http://www.pamelasargent.com/the_millennium_interview.html $>$.

"Science in Fiction: Interview with novelist Jeanette Winterson." New Scientist 195.2618 (25 Aug. 2007): 50-51. Academic Search Complete. Retrieved from EBSCOHost.

Scholes, Robert. Structural Fabulation: An Essay on Fiction of the Future. Notre Dame: U of Notre Dame P, 1975.

Schroeder, Steven. "Mother of All Battles.” PMLA 124.5 (October 2009): 1690-1703.

Shapiro, Kevin. "Global Warming: Apocalypse Now?" Commentary (September 2006): n.p. Web. $<$ https://www.commentarymagazine.com/viewarticle.cfm/global-warming-apocalypse-now--10110?page $=$ all $>$.

Shelley, Mary. The Last Man. London: Wordsworth, 2004.

Smith, Anna Deveare. "From Twilight: Los Angeles, 1992." The Longman Anthology of Drama and Theatre: A Global Perspective. Ed. by Michael L. Greenwald, Roger Schultz, and Roberto D. Pomo. New York: Longman, 2001. 1728-1754.

Smith, Henry Nash. Virgin Land: The American West as Symbol and Myth. Cambridge: Harvard UP, 1950.

Snitow, Ann Barr. "Mass Market Romance: Pornography for Women is Different." Powers of 
Desire: The Politics of Sexuality. Ed. by Ann Snitow, Christine Stansell, and Sharon Thompson. New York: Monthly Review P, 1983. 245-263.

Sontag, Susan. Regarding the Pain of Others. New York: Picador, 2003.

Stacewicz, Richard. Winter Soldiers: An Oral History of the Vietnam Veterans Against the War. Chicago: Haymarket, 2008.

Stillman, Peter G. "Dystopian Critiques, Utopian Possibilities, and Human Purposes in Octavia Butler's Parables." Utopian Studies 14 (2003): 15-35. Retrieved from EBSCOHost.

Suleiman, Susan Rubin. "The Fate of the Surrealist Imagination in the Society of the Spectacle." Flesh and the Mirror: Essays on the Art of Angela Carter. Ed. by Lorna Sage. London: Virago, 2001. 98-116.

---. Subversive Intent: Gender, Politics, and the Avant-Garde. Cambridge: Harvard UP, 1990.

Suvin, Darko. Metamorphoses of Science Fiction: On the Poetics and History of a Literary Genre. New Haven: Yale UP, 1979.

The Day After Tomorrow. Dir. Roland Emmerich. Lions Gate Films, 2004. DVD.

Third, Amanda. “'Shooting From the Hip': Valerie Solanas, SCUM and the Apocalyptic Politics of Radical Feminism.” Hecate 32.2 (2006): 104-132. Retrieved from EBSCOHost.

Tompkins, Jane. West of Everything: The Inner Life of Westerns. New York: Oxford UP, 1992.

Turner, Matthew R. "Cowboys and Comedy: The Simultaneous Deconstruction and Reinforcement of Generic Conventions in the Western Parody." Hollywood's West: The American Frontier in Film, Television, and History. Ed. by Peter C. Rollins and John E. O’Connor. Lexington: UP of Kentucky, 2005. 218-235.

Tuan, Yi-Fu. Space and Place: The Perspective of Experience. Minneapolis: U of Minnesota P, 1977. 
Vandermeer, Jeff. “The New Weird: It's Alive?” The New Weird. Ed. by Ann and Jeff

Vandermeer. San Francisco: Tachyon Publications, 2008. ix-xviii.

Vint, Sherryl. "Introduction: Special Issue on China Miéville." Extrapolation 50.2 (Summer 2009): 197-199.

Virtual Hell. Just 4 Kids Magazine, n.d. Web. 31 October 2010.

$<$ http://www.just4kidsmagazine.com/hell/main.html $>$.

Warner, Marina. From the Beast to the Blonde: On Fairy Tales and their Tellers. New York:

Farrar, Straus, and Giroux, 1994.

Williams, Raymond. The Country and the City. New York: Oxford UP, 1973.

Willis, Ellen. "Feminism, Moralism, and Pornography." Powers of Desire: The Politics of

Sexuality. Ed. by Ann Snitow, Christine Stansell, and Sharon Thompson. New York: Monthly Review P, 1983. 460-467.

Winterson, Jeanette. The Stone Gods. New York: Harcourt, 2007.

Woolf, Virginia. Three Guineas. New York: Harcourt, 1966.

Worden, Daniel. "Neo-liberalism and the Western: HBO's Deadwood as National Allegory." Canadian Review of American Studies 39.2 (2009): 221-246. EBSCO. 11 November 2009.

World of Warcraft. Irvine: Blizzard Entertainment, 2004. DVD-ROM.

Worster, Donald. Under Western Skies: Nature and History in the American West. New York: Oxford UP, 1992.

Yaszek, Lisa. "Afrofuturism, science fiction, and the history of the future." Socialism and Democracy 20.3 (November 2006): 41-60. EBSCO via ILLiad. Web. 9 February 2010. Zimmerman, Bonnie. "What Has Never Been: An Overview of Lesbian Feminist Literary 
Criticism." The New Feminist Criticism: Essays on Women, Literature, and Theory. Ed.

by Elaine Showalter. New York: Pantheon, 1985. 200-224.

Žižek, Slavoj. Violence. New York: Picador, 2008.

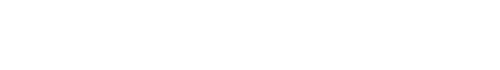

